\title{
HEALTH RISK ANALYSIS FOR INGESTION OF CONTAMINANTS FROM EXISTING GROUNDWATER CONTAMINATION AT SELECTED UMTRA PROJECT SITES
}

L. D. Hamilton, W. H. Medeiros, A. Meinhold

S. C. Morris, P. D. Moskowitz, and J. Nagy

September 1988

BIOMEDICAL AND ENVIRONMENTAL ASSESSMENT DIVISION

DEPARTMENT OF APPLIED SCIENCE BROOKHAVEN NATIONAL LABORATORY ASSOCIATED UNIVERSITIES, INC.

Under Contract No. DE-AC02-76CH00016 with the

U. S. Department of Energy 


\section{DISCLAIMER}

This report was prepared as an account of work sponsored by an agency of the United States Government. Neither the United States Government nor any agency thereof, nor any of their employees, not any of their contractors, subcontractors, or their employees, makes any warranty, exprese or implied, or assumes any legal liability or responsibility for the accuracy, completeness, or usefulness of any information, apparatus, product, or process disclosed, or represents that its use would not inf ringe privately owned rights. Reference herein to any specific commercial product, process, or service by trade name, trademark, manufacturer, or otherwise, does not necessarily constitute or imply its endorsement, recommendation, or favoring by the United States Government or any agency, contractor, or subcontractor thereof. The views and opinions of authors expressed herein do not necessarily state or reflect those of the United States Government or any agency, contractor or subcontractor thereof.

Printed in the United States of America

Available from

National Technical Information Service

U.S. Department of Commerce S285 Port Royal Road

Springfield, VA 22161 


\begin{abstract}
This study examines potential hazards to human health from the ingestion of chemicals in ground waters beneath and adjacent to four abandoned uranium mill-tailings sites: Gunnison, Colorado; Lakeview, Oregon; Monument Valley, Arizona; and Riverton, Wyoming. Chemicals of concern in the ground water near these sites include arsenic, cadmium, chromium, lead-210, molybdenum, nitrate; polonium-210, radium 226 and radium 228, selenium, sulfate, thorium-230, uranium and vanadium. Hazards to health were evaluated by implementing the method outlined in the Environmental Protection Agency's Superfund Public Health Evaluation Manual. Conservative assumptions in the method, and the effect of these on the risk estimates and EPA's indices of harm are discussed. Because the method has a number of built-in conservatisms, the estimated risks and indices only indicate sites and chemicals requiring further analysis. The chemicals and sites identified as presenting risk in this first screening step should be investigated in more detail. Necessary steps are given. Sites and chemicals identified as harmless in this initial screening can be eliminated from further consideration.
\end{abstract}




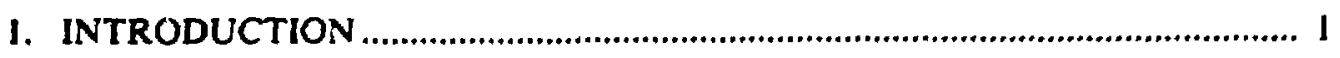

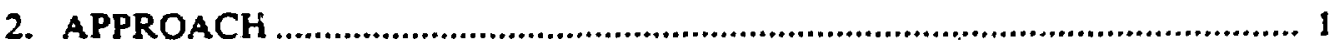

2.1 Exposure Assessment ............................................................................ 1

2.2 Dose-Response Assessment, .................................................................... 2

2.3 Risk Characterization............................................................................ 4

3. SITE SPECIFIC ANALYSES................................................................... 5

3.1 Gunnison, Colorado .................................................................................. 6

3.1.1 Ground Water Geology, Flow and Water Quality ....................... 6

3.1.2 Water Use .................................................................................... 8

3.1.3 Risk Assessment ........................................................................ 8

3.1.4 Summary .................................................................................. 9

3.2 Lakeview, Oregon ...................................................................................... 9

3.2.1 Ground Water Geolcgy, Flow and Water Quality ...................... 9

3.2.2 Water Use .......................................................................................11

3.2.3 Risk Assessment ..........................................................................11

3.2.4 Summary ...................................................................................

3.3 Monument Valley, Arizona .....................................................................13

3.3.1 Ground Water Geology, Flow and Water Quality ......................13

3.3.2 Water Use .......................................................................................13

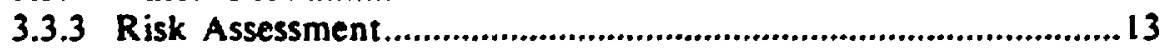

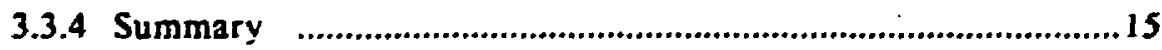

3.4 Riverton, Wyoming ....................................................................................16

3.4.1 Ground Water Geology, Flow and Water Quality .......................16

3.4.2 Water Use .................................................................................18

3.4.3 Risk Assessment .....................................................................18

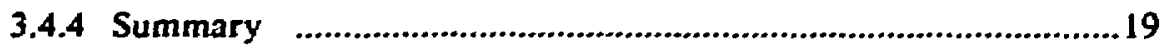

4. DISCUSSION

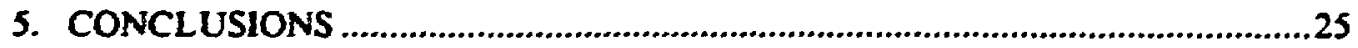

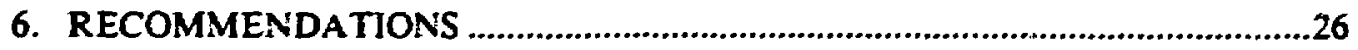

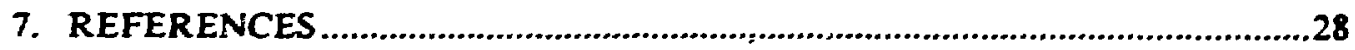

APPENDIX A - Derivation of Dose-Response Coefficients: Acceptable Intake for Subchronic Exposure (AIS), the Acceptable Intake for Chronic Exposure (AIC), and Carcinogen Potency Factor ...................................................29

APPENDIX B - Federal Standards for Selected Constituents...............................36

APPENDIX C - Compiled Concentration Data, Ratios and Risk Estimates for Uranium Mill-Tailings Sites .................................................38

APPENDIX D - Critical Evaluation of EPA and ICRP Cancer Risk Models.....79 


\section{TABLES}

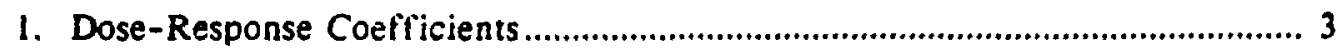

2. Maximum Estimated Subchronic Health Risks .............................................2I

3. Maximum Estimated Chronic Health Risks ..............................................22

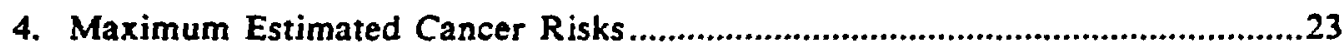

\section{FIGURES}

1. Uranium Mill-tailing Site at Gunnison, Colorado ........................................ 7

2. Uranium Mill-tailing Site at Lakeview, Oregon........................................... 10

3. Uranium Mill-tailing Site at Monument Valley, Arizona...............................14

4. Uranium Mill-tailing Site at Riverton, Wyoming........................................17 


\section{INTRODUCTION}

This study examines potential hazards to human health from ingestion of chemicals in ground waters beneath and adjacent to abandoned uranium mill-tailings sites: Riverton, Wyoming; Monument Valley, Arizona; Gunnison, Colorado; and Lakeview, Oregon. The contaminants studied are arsenic, cadmium, chromium VI, lead-210, molybdenum, nitrate, polonium-210, radium-226 and radium-228, selenium, sulfate, thorium-230, natural uranium, and vanadium. These sites and chemicals were selected for this analysis by the U.S. Department of Energy Uranium Mill-tailings Remedial Action (DOE-UMTRA) Project Office in Albuquerque, New Mexico. Potential hazards to public health were evaluated by implementing the method used by the U.S. Environmental Protection Agency (EPA) at Superfund sites. Because of built-in conservatisms in this method, estimates which have large risks should only be used to indicate sites and chemicals requiring more detailed analysis. Conversely, sites and chemicals not indicating large risks can be eliminated from further consideration. The EPA method is essentially a . screening procedure rather than an analysis of realistic risk.

\section{APPROACH}

Contaminants presenting potentially substantial hazards to public health at the four sites were identified using procedures outlined in the Superfund Public Health. Evaluation Manual, here called the "Manual", (USEPA, 1986a) and in related reports prepared by EPA (USEPA, 1986b); the U.S. Agency for Toxic Substances and Disease Registry (ATSDR, undated); and the International Commission on Radiological Protection (ICRP 1977; ICRP 1979). The method outlined in these reports can be civided into three steps: Exposure Assessment, Dose Response Assessment, and Risk Characterization.

\subsection{Exposure Assessment}

The purpose of this step in hazard assessment is to estimate public exposure levels from consuming drinking water potentially impacted by chemicals leached from uranium mill-tailings sites. The Manual outlines a very conservative approach to estimate human exposures. More specifically, the Manual suggests that exposure estimates be based on the highest observed concentration for each chemical among all monitoring wells, irrespective of their location or distance from public wells, or public use. In this context, exposure estimates in this report are 
based on: (i) the highest concentration of the identified chemicals detected in domestic, industrial, or agricultural receptor wells; (ii) the highest concentration of the identified chemicals detected in off-site monjtoring wells; and (iii) the lowest observed concentrations in any background wells. Use of these measurements results in exposure estimates that are much larger than actual or potential exposures for several reasons. First, if large concentrations were measured in wells used for drinking water, use of these waters would be restricted. Monitor wells routinely show higher levels of contaminants than wells actually being used for drinking water. Second, use of the lowest observed background concentration may overestimate the contribution of any specific contaminant from the mill-tailings sites. Third, use of the maximum concentration detected in monitor and receptor welis overestimates the exposure because most wells contain much lower concentrations.

\subsection{Dose-Response Assessment}

Dose-response information is needed to evaluate hazards to human health associated with estimated exposure levels. The three toxicologic end-points in the Manual are the Acceptable Intake for Subchronic Exposure (AIS), the Acceptable Intake for Chronic Exposure (AIC), and the Carcinogenic Potency Factor.

The AIS represents the highest human intake rate of a chemical, expressed in milligrams ingested per day per kilogram of bodyweight $(\mathrm{mg} /$ day $/ \mathrm{kg})$, that does not cause adverse effects when exposure is short-term, but not acute. The AIS is usually based on subchronic animal studies.

The AIC represents the highest human intake of a chemical, expressed as $\mathrm{mg} / \mathrm{day} / \mathrm{kg}$, that does not cause adverse effects when exposure is long-term (lifetime). The AIC is usually based on chronic animal studies.

The Carcinogenic Potency Factor represents the carcinogenic potential of a chemical, expressed as cancer risk per $\mathrm{mg} / \mathrm{day} / \mathrm{kg}$ for nonradiologic pollutants, and as cancer risk per $\mathrm{pCi} / \mathrm{day} / \mathrm{kg}$ for radiologic pollutants. In both, the risks are from life-long intake. The Potency Factor for non-radiological effects is based on extrapolations from human. data, when available, or chronic animal studies; for radiological effects, they are based on models and extrapolations from human data.

The AIS, AIC and Potency Factors for the contaminants studied are shown in Table 1. In this screening study, dose-response coefficients developed by EPA or ICRP were used for arsenic, cadmium, chromium, lead-210, nitrate, polonium-210, radium 226 , radium 228 , thorium-230, and natural uranium. Independent estimates were developed for molybdenum, sulfate and vanadium 
Table 1. Dose-Response Coefficients.

\begin{tabular}{|c|c|c|c|c|c|c|}
\hline \multirow[b]{2}{*}{ Chemical } & \multirow{2}{*}{$\begin{array}{c}\text { AIS } \\
\text { (ng/kg/day) }\end{array}$} & \multirow[b]{2}{*}{$(\mathrm{mg} / \mathrm{l})$} & \multirow{2}{*}{$\begin{array}{c}\text { AIC } \\
(\mathrm{mg} / \mathbf{k g} / \text { day })\end{array}$} & \multirow[b]{2}{*}{$(\mathrm{mg} / \mathrm{l})$} & \multicolumn{2}{|c|}{ Potency Factor } \\
\hline & & & & & EPA & ICRP \\
\hline Arsenic & $1.40 \mathrm{E}-03$ & 0.050 DWHA & $1.40 \mathrm{E}-03$ & 0.050 DWHA & $1.50 \mathrm{E}+01$ & \\
\hline Cadmium & $1.20 \mathrm{E}-03$ & 0.043 DWHA & $2.90 \mathrm{E}-04$ & $0.010 \mathrm{HEA}$ & & \\
\hline Chromium (III) & $1.40 \mathrm{E}+01$ & 490 Rfd & $1.00 \mathrm{E}+00$ & $52 \mathbf{R f d}$ & & \\
\hline Chromium (VI) & $2.50 \mathrm{E}-02$ & 0.870 HEA & $5.00 \mathrm{E}-03$ & 0.170 HEA & & \\
\hline Lead-210 & & & & & $1.40 E-04$ & $1.14 \mathrm{E}-03$ \\
\hline Molybdenum & & & $2.90 \mathrm{E}-03$ & & & \\
\hline Nitrate & $1.10 \mathrm{E}+01$ & 44 DWHA & $1.26 \mathrm{E}+00$ & 44 DWHA & & \\
\hline Polonium-210 & & & & & $3.68 \mathrm{E}-04$ & $3.65 \mathrm{E}-04$ \\
\hline Radium-226 & & & & & $3.08 \mathrm{E}-04$ & $2.47 \mathrm{E}-0.4$ \\
\hline Radium-228 & & & & & $2.31 \mathrm{E}-04$ & 2.77E-04 \\
\hline Selenium & $3.20 \mathrm{E}-03$ & 0.110 HEA & $3.00 \mathrm{E}-03$ & 1.00E-01 HEA & & \\
\hline Sulfate & & & $4.00 \mathrm{E}+01$ & & & \\
\hline Thorium-230 & & & & & 7.70E-05 & $1.18 \mathrm{E}-04$ \\
\hline Uranium & & & $1.70 \mathrm{E}-03$ & 0.060 & $4.73 E-05$ & $5.49 E-05$ \\
\hline Vanadium & $1.00 \mathrm{E}-02$ & 0.350 & $2.00 \mathrm{E}-02$ & $0.175 \mathrm{Rfd}$ & & \\
\hline
\end{tabular}

Definitions:

AIS - Acceptable Intake for Subchronic Exposure. The highest human intake of a chemical, expressed as $\mathrm{mg} / \mathrm{kg} /$ day, that does not cause adverse effects when exposure is short-term (but not acute). The AIS is usually based on subchronic animal studies.

AIC - Acceptable Intake for Chronic Exposure. The highest human intake of a chemical, expressed as $\mathrm{mg} / \mathrm{kg} / \mathrm{day}$, that does not cause adverse effects when exposure is long-term (lifetime). The AIC is usually based on chronic animal studies.

DWHA - EPA Drinking Water Health Advisory (1 day or lifetime limit).

HEA - Health Effects Assessment, prepared by the Environmental Criteria and Assessment Office, USEPA, Cincinnati, Ohio, 1985 (updated May, 1986)

Rfd - Azency-wide reference dose value, developed by an interoffice work group chaired by the Office of Research and Development, USEPA, Washington, DC, 1986. 
(AIS only) because EPA has not done so (details on the derivations of these coefficients are given in Appendix A).

As with exposure assessment, the coefficients included in this study are also conservative. AIS and AIC values incorporate safety factors to extrapolate from "no observed effects levels" in animal and human studies to estimated intakes which are assumed to present minimal health risks. Similarly, carcinogenic potency factors are often based on extrapolations from studies in which laboratory animals were exposed to pollutant concentrations much higher than those measured in the general public. Section 4 details the conservatisms in these coefficients.

\subsection{Risk Characterization}

Risk Characterization combines the toxicologic and concentration data to estimate risks to human health associated with consumption of contaminated drinking water. Estimates are prepared for acute, chronic, and carcinogenic hazards. For acute and chronic hazards, ratios of the quantities of materials ingested vs. the quantities hazardous to human health are developed. Calculated ratios greater than 1.0 indicate that a potential hazard to health ceuld arise from continued consumption of contaminated drinking water. For carcinogens, the estimated probability of an individual developing cancer is estimated. In this context, life-time risk estimates less than $10^{-6}$ of ten are viewed as de minimus by EPA and other regulatory agencies. Similarly, EPA and others of ten implement control requirements when risks exceed $10^{-4}$. Risks in the range of $10^{-4}$ to $10^{-6}$ are reviewed on a case-by-case basis to determine whether controls are needed.

In this specific analysis, it is important to note that for arsenic, cadmium, molybdenum, uranium, and vanadium federal drinking water standards can be met, even though the ratio value of 1.0 maybe exceeded. This occurs when the calculated ratio is based on an intake or effect in children, or in adults not considered in the drinking water standard. Conversely, drinking water standards are more stringent than the ratio test for chromium, selenium, and sulfate. Similarly, for cancer risks, many of the chemicals studied exceed the $1 \times 10^{-6}$ risk level for cancer, but are below the risk level implied by the drinking water standard. This occurs when the $1 \times 10^{-6}$ risk level has not been used in the development of the standards, for example lead-210 and polonium210. 


\section{SITE SPECIFIC ANALYSES}

To evaluate potential hazards to health from chemicals in ground water beneath or adjacent to the four UMTRA sites, the EPA Superfund Manual method was implemented.

Inputs to the EPA method include concentration data for three different well types: receptor, monitor and background. Background wells are located upgradient of the site, and provide an estimate of the water quality near the site independent of any impact from the milltailings site. Receptor wells are domestic, agricultural or industrial wells located downgradient of the tailings site. These wells represent a real potential for exposure to contaminated water because they are being used. Monitor wells are wells located downgradient of the tailings pile, beginning just offsite. Relative to receptor wells, monitor wells are generally closer to the tailings pile, are more likely to be completed in shallow aquifers, and show higher levels of contamination.

Pollutant concentrations were measured in a number of wells, and some wells were sampled a number of times. These concentrations reflect random, and possible real variations in pollutant concentration among measurements, over time and space, and among different wells in the same class (background, monitoring, or receptor). Faced with a potentially large set of measurements for each of the three classes, and keeping with the conservative approach of the study, both the "gross" and "net" concentrations were used. The "gross" concentration was the maximum concentration detected for a particular contaminant in any monitor or receptor well. The "net" concentration was calculated as the highest receptor (or monitoring) well measurement minus the lowest background well measurement for that contaminant. This will overstate the impact of the tailings pile on the receptor or monitoring wells.

In interpreting any set of environmental measurements, how to handle measurements that were below the limits of detection (LOD) is always a question. It was decided to treat them as zero. Since the highest measurements were taken from the monitoring and receptor wells, this problem should not arise there unless the pollutant is consistently below LOD for all measurements. In that case, clearly there is no risk. The effect falls on the calculation of net exposure; when at least one measurement in a background well is below LOD, background is taken as zero for the calculation of net exposure. In that case, net exposure is calculated to equal gross exposure. This has a further conservative effect of overestimating the contribution of the tailings piles to exposure.

For each site and aquifer, exposure and intake levels were estimated using standard reference factors (e.g., children consume 1 liter per day of water and weigh 10 kilograms, and adults consume 2 liters per day of water and weigh 70 kilograms). Eight different intakes were estimated for each pollutant. Receptor Adult (Gross) and Receotor Child (Gross) represent the 
estimated intakes for an adult and child drinking water from a "receptor well." Receptor Adult (Net) and Receptor Child (Net) also represent the estimated intakes for an adult and child drinking water from a "receptor well"; but in these calculations, the marginal increment over background wells is given. Parallel estimates were also developed for the Monitor Wells (Gross) and (Net). (Net) values are smaller than or equal to the (Gross) values; (Gross) and (Net) estimates are equal only when the contaminant was not detected in the background monitoring wells.

Concentration data for the calculations were abstracted from the Remedial Action Plans and Environmental Assessments for the four sites and from supplemental data provided by the Uranium Mill-tailings Project Office in Albuquerque, New Mexico. At each site, concentration data were compiled separately for each aquifer.

Calculated intake levels were then compared with defined AIS, AIC and Potency Factors to evaluate hazards presented by these materials. For the noncarcinogenic chemicals, a comparison was also made to current and proposed drinking water standards (See Appendix B). For the carcinogens lifetime cancer risks were calculated corresponding to drinking water standards. The compiled data and analyses for each site are given beiow. The data and analyses presented are all based on the maximum concentration for each pollutant in monitor and receptor wells.

\subsection{Gunnison, Colorado}

\subsubsection{Ground Water Geology, Flow and Water Quality}

The mill-tailings site at Gunnison, Colorado (Figure 1) overlies alluvial deposits produced by the confluence of the Gunnison and Tomichi Rivers. The general flow direction in the alluvium at Gunnison is south south-west. Anisotropies caused by buried stream channels may divert some flow from the general direction. No confining layer was detected during well drilling. but the existence of a semi-confining layer composed of silt and clay lenses is suspected based on the results of pump tests. High concentrations of contaminants are more common in shallow than deeper wells. This analysis treated the system impacted by the tailings pile as a single aquifer because the available data did not clearly differentiate between shallow and deep ground water zones.

Most of the native ground water in the area is potable. There is a reducing zone along the river that contains high levels of hydrogen sulfide. There are high concentrations of iron in the alluvial aquifer. High concentrations of nitrate near the pile probably result from a nearby sewage-treatment plant. Tailings-pore water from the Gunnison site contains high concentrations of uranium, sulfate, iron and heavy metals. A defined plume of sulfate and uranium has migrated from the pile and is impacting monitoring and domestic wells in the area. 


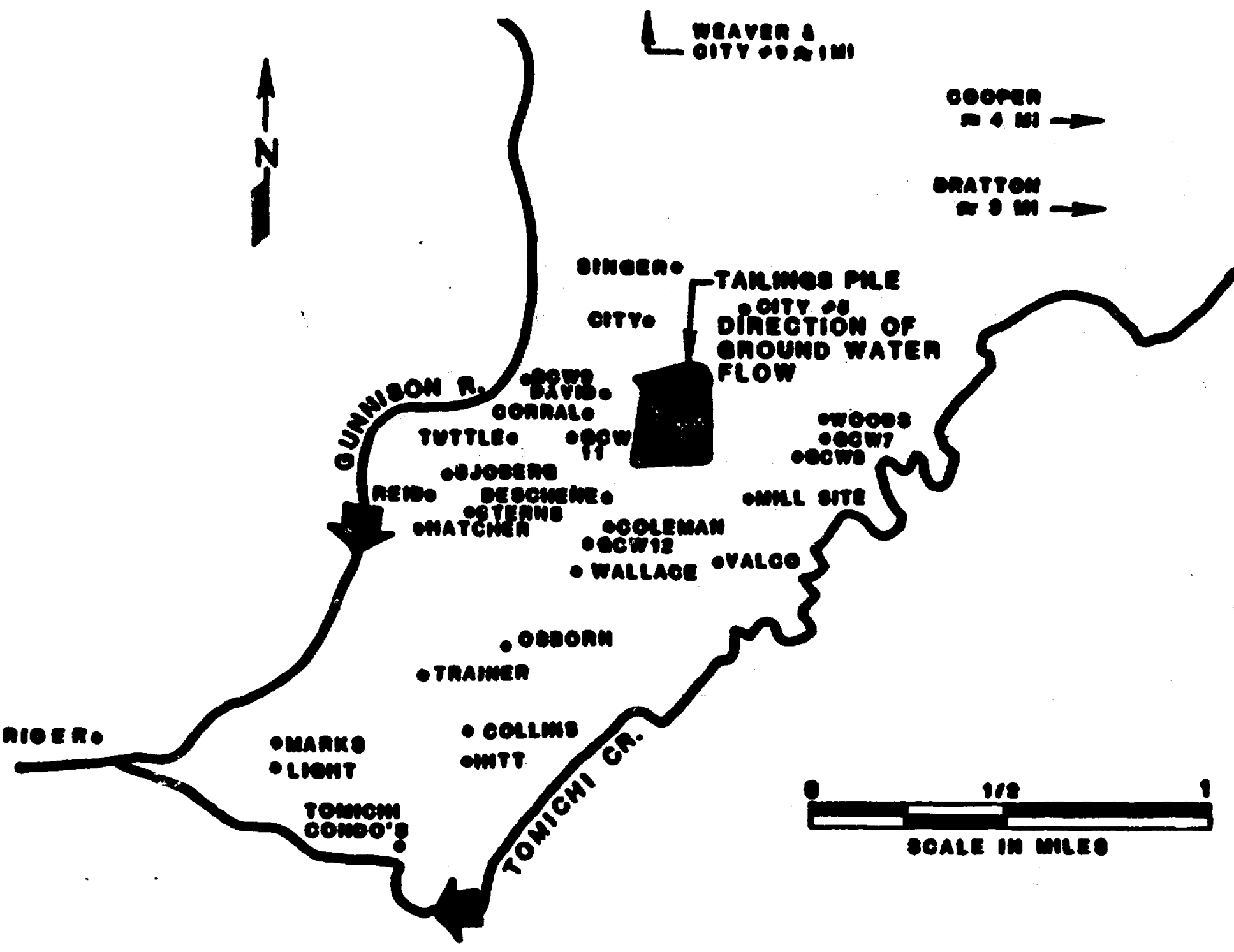

Figure 1. Mill-Tailings Site at Guanison, Colorado.

(Domestic Wells Sampled; modified from DOE, 1984) 


\subsubsection{Water Use}

Ground water is the major source of drinking water in the Gunnison area. The City of Gunnison has nine wells in the alluvial system. All of these wells are located upgradient of the tailings pile. Domestic wells are in the alluvium along the river. There are approximately 80 private, domestic wells downgradieni of the tailings pile.

\subsubsection{Risk Assessment}

Appendix $\mathrm{C}$ presents compiled concentration data, ratios and risk estimates for monitor and receptor wells at Gunnison. At this site concentrations above detectable limits were measured at either receptor or monitor wells for all pollutants except cadmium and polonium. Concentrations of most pollutants were greater at monitor wells than at receptor wells. Minimum background concentrations for all measured pollutants, except sulfate and uranium, were below detectable levels.

Chronic/Subchronic Ratios and Drinking Water Standards - Only arsenic exceeded the ratio of 1.0 for AIS's (2.9 in the maximum monitor well). For the AIC's, the maximum monitor wells showed exceedances for arsenic (2.9), sulfate (2.3) and uranium (4.1). Molybdenum did not exceed the recommended ratio but was high in monitoring wells (1.0). The maximum receptor well for uranium exceeded the recommended ratio (7.1). Subtracting the minimum background concentrations detected from the maximum concentrations in monitor and receptor wells did not substantially change the calculated ratios.

Drinking water standards were exceeded in the maximum monitor wells for uranium and sulfate. The maximum receptor well exceeded drinking water standards for selenium and uranium. All other contaminants were below drinking water standards in receptor and monitor wells.

Cancer Risk Estimates - Based on a lifetime cancer risk of $1 \times 10^{-6}$, the maximum monitor wells at Gunnison are potentially of concern for arsenic $\left(1.7 \times 10^{-2}\right)$, radium $226+228(3.6$ $\times 10^{-5}$, ICRP estimate) and uranium $\left(7.4 \times 10^{-5}\right.$, ICRP). These contaminants are also flagged using the less conservative risk level of $1 \times 10^{-5}$. The risk estimates calculated using drinking water standards are exceeded only for uranium.

For the maximum receptor wells, the $1 \times 10^{-6}$ risk level is exceeded for lead $-210(1.1 \times$ $10^{-4}$, ICRP), radium $226+228\left(4.4 \times 10^{-6}\right)$, thorium-230 $\left(3.0 \times 10^{-6}\right.$, ICRP) and uranium (1.3 $x$ $\left.10^{-4}, 1 C R P\right)$. Compared to the $1 \times 10^{-5}$ risk level, only lead -210 and uranium show exceedances in maximally contaminated receptor wells. The risk estimates based on drinking water standards were exceeded for uranium in monitor and receptor wells.

Subtracting the minimum background concentrations did not appreciably change the lifetime cancer risk estimates. 


\subsubsection{Summary}

Contaminants exceeding the ratio of 1.0 and risk levels of $1 \times 10^{-6}$ are arsenic, sulfate, uranium, and radium $226+228$ in monitor wells, and uranium, lead-210, radium $226+228$ and thorium-230 in receptor wells. For chronic and subchronic effects, contaminants flagged as exceeding both the ratio of 1.0 and the current or proposed drinking water standards include sulfate and uranium in monitor wells and uranium in receptor wells. For cancer, contaminants flagged as exceeding a lifetime risk estimate of $1 \times 10^{-6}$ and the risk estimate based on drinking water standards include only uranium in receptor and monitor wells.

At Gunnison, the tailings pile has created a well defined plume of sulfate and uranium. Other contaminants flagged as exceeding standards, ratios and risk levels may come from the min:tailings pile, but in less obvious patterns. These contaminants will require further investigation of concentration distributions to develop a reasonable estimate of exposure. A number of the contaminants flagged using this conservative approach may not show exceedances when more realistic estimates of background concentrations are used in the analysis.

The aquifer at Gunnison downgradient of the tailings site is used for drinking water. No municipal wells have been affected or are threatened by contamination from the tailings pile. However, approximately 80 private domestic wells have been or have the potential of being affected, primarily by elevated levels of uranium.

\subsection{Lakeview, Oregon}

\subsubsection{Ground Water Geology, Flow and Water Quality}

Ground water at the Lakeview mill-tailings site (Figure 2) is under unconfined to confined conditions. The ground water can be characterized as a multiple aquifer system with a general flow from the northeast to the southwest. A succession of leaky aquifers are separated by aquitards of varying thickness and lateral extent. Within the first 100 feet, ground water is under unconfined to semi-confined conditions within the unconsolidated deposits. Two ground water zones were investigated. The shallow zone is above $30 \mathrm{feet}$, and the deeper zone at 60-70 feet. There is a small potential for the downward migration of water from the shallow to the deeper zone. The site lies within a Known Geothermal Resource Area (KGRA) and a number of geothermal anomalies were observed.

Two different background geochemical facies exist at the Lakeview site; they interact differently with the seepage from the tailings pile and evaporation ponds. Low temperature background water has low or below detectable concentrations of most contaminants. The milltailings pile (and evaporation ponds) have caused a plume of sulfate in the shallow ground water. Sulfate downgradient of the site comes from the tailings pile (and evaporation ponds) and 


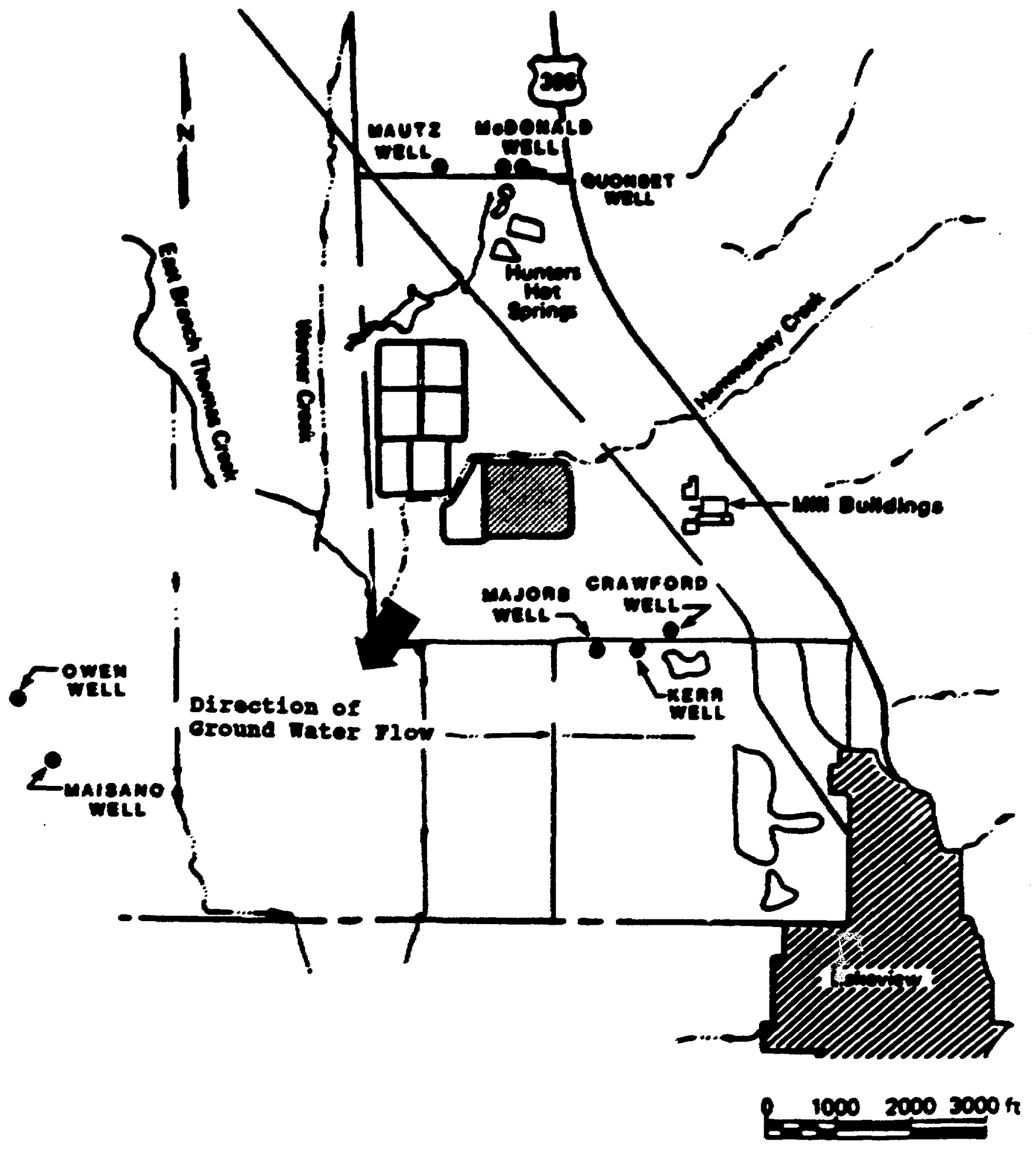

Figure 2. Mill-Tailings Site at Lakeview, Oreson.

(Orfsite Well Locations; modified (rom DOE, 1985) 
geothermal water. Geothermal background water is high in arsenic and sulfate. No sampled domestic wells have been affected, primarily because they are screened at depths of 100-300 feet.

\subsubsection{Water Use}

Ground water is the main source of drinking water in the Lakeview area. The city of Lakeview operates 12 municipal wells. These are completed at depths of 350 to 2050 feet and are located more than one mile south of the mill-tailings site. There are 97 registered wells within a 2-mile radius of the Lakeview site. Twelve of these are drilled above 50 feet, and all but one of these shallow wells is located more than 0.5 miles south of the site. Most wells in the area are drilled to a depth of 100-300 feet, and are used for domestic, stock and irrigation purposes. There are approximately 20 to 40 domestic wells in the sections adjacent to and downgradient of the Lakeview site.

\subsubsection{Risk Assessment}

Appendix $C$ presents concentration data and risk estimates for shallow and deep ground water zones at Lakeview. There were no samples from shallow receptor wells downgradient of the Lakeview site.

At this site two ground water zones were investigated. In the shallow offsite monitor wells, concentrations above detectable limits were observed for all measured pollutants except lead and selenium. In contrast, in the deep zone only arsenic, nitrate and vanadium were detected in the maximum receptor wells. In the monitor wells, however, the situation reversed. All chemicals except lead, selenium and vanadium were found.

Chronic/Subchronic Risk and Drinking Water Standards - In the maximally contaminated shallow monitor wells, ratios for the AIS and AIC which exceeded the ratio of 1.0 included arsenic (7.1, 7.1), cadmium (2.6, 11), molybdenum (not applicable, 6.2) and sulfate (not applicable, 7.9). In maximum deep monitor wells, the AIS ratio of 1.0 was exceeded for arsenic (1.4). The ratio for AIC's was exceeded in deep monitor wells for arsenic (1.4), cadmium (2.1) and molybdenum (1.4). No receptor wells exceeded the 1.0 ratio for any contaminants. Subtraction of the minimum background concentrations for each contaminant did not affect the calculated ratios.

Drinking water standards were exceeded in shallow monitor wells for arsenic, cadmium, molybdenum and sulfate. Concentrations in maximum deep monitor wells exceeded the standards for sulfate. Concentrations of all contaminants studied were below drinking water standards for deep receptor wells.

Cancer Risk Estimates - For several chemicals, concentrations indicated a lifetime risk level exceeding $1 \times 10^{-6}$ in the shallow monitor wells at Lakeview: arsenic $\left(4.3 \times 10^{-2}\right)$, polonium$210\left(9.6 \times 10^{-5}\right)$, radium $226+228\left(2.3 \times 10^{-5}\right.$, ICRP), thorium-230 (5.4 $\times 10^{-6}$, ICRP), and uranium (3.2 $\times 10^{-6}$, ICRP). A risk level of $\mathrm{J} \times 10^{-5}$ was exceeded for arsenic, polonium-210, 
and radium $226+228$ in the shallow zone. The risk estimates based on drinking water standards are exceeded only for arsenic in shallow monitor wells.

Deep monitor wells at Lakeview exceed the $1 \times 10^{-6}$ risk level for arsenic $\left(8.6 \times 10^{-3}\right)$, polonium-2 $10\left(4.6 \times 10^{-5}\right)$, radium $226+228\left(2.3 \times 10^{-5}\right.$, ICRP), thorium-230 $\left(1.1 \times 10^{-5}\right.$, ICRP) and uranium $\left(1.4 \times 10^{-6}, \mathrm{ICRP}\right)$. A risk level of $1 \times 10^{-5}$ was exceeded for arsenic, polonium210 , radium $226+228$ and thorium-230 in deep monitor wells. Deep receptor wells exceed the $1 \times$ $10^{-6}$ risk level only for arsenic $\left(4.7 \times 10^{-3}\right)$. The risk estimates based on drinking water standards are not exceeded for any deep wells at Lakeview. The risk estimates are not appreciably affected by subtraction of the minimum background concentrations.

\subsubsection{Summary}

Contaminants exceeding the ratio of 1.0 for AIC or AIS and/or the $1 \times 10^{-6}$ risk level for cancer include arsenic, cadmium, molybdenum, sulfate, uranium, polonium-210, radium $226+228$ and thorium-230 in shallow monitor wells, and arsenic, cadmium, molybdenum, uranium, polonium-210, radium $226+228$, and thorium-230 in deep monitor wells. Receptor wells exceeded the $1 \times 10^{-6}$ risk level for arsenic.

For chronic and subchronic effects, contaminants flagged as exceeding both the drinking water standard and the 1.0 ratio include arsenic, cadmium, molybdenum, and sulfate in shallow monitors, and no contaminants in deep monitors or receptors. For cancer risk, only arsenic in shallow monitor wells exceeds the risk estimates based on drinking water standards and a lifetime risk estimate of $1 \times 10^{-6}$.

At Lakeview, the tailings pile has created a plume of sulfate in the ground water downgradient of the site. The sulfate detected in the monitoring wells has two sources - the milltailings pile ( and evaporation ponds), and the background geothermal water. Elevated arsenic levels in shallow monitor wells may be wholly or partially due to the influence of the geothermal background water in the area. The other contaminants of potential concern may originate in the tailings pile, but a more detailed study of their distribution in background and impacted wells is needed to better estimate exposure. A number of the contaminants identified as being of concern in this conservative assessment may not show exceedances when more realistic estimates of background concentrations are used.

Contamination from the tailings pile is largely restricted to a shallow zone of less than 50 feet. No receptor wells have been impacted because the shallow zone is not used as a source of drinking water in the Lakeview area. Most domestic wells are screened at depths of 100 to 300 feet, and municipal wells at depths of 350 to 2050 feet. 


\subsection{Monument Valley, Arizona}

\subsubsection{Ground Water Geology, Flow and Water Quality}

The mill-tailings site at Monument Valley, Arizona (Figure 3) overlies three aquifers. The uppermost aquifer consists of alluvium and dune sand. The Shinarump Member of the Chinle Formation underlies the alluvium. An aquitard separates the Shinarump from the deeper aquifer system, the DeChelly Sandstone. All three aquifers flow to the north. There is an upward hydraulic gradient from the DeChelly aquifer into the Shinarump and alluvial systems. This suggests that there is no force driving contaminated ground water down into the deeper aquifer.

Lysimeter samples from the tailings piles and an evaporation pond contain elevated concentrations of silfate, nitrate, radium- 226 , uranium and vanadium. Soil and pore water extracts from the piles contain elevated levels of arsenic, cadmium, sulfate, uranium and vanadium.

Seepage from the tailings piles and evaporation pond has impacted ground water downgradient of the site. Plumes of sulfate, nitrate and uranium were identified in the alluvial system. The Shinarump and DeChelly aquifers have each shown elevated concentrations of contaminants in one well. For the most part, the deeper aquifers downgradient of the pile have not been affected.

\subsubsection{Water Use}

The area around Monument Valley is sparsely populated and there are no municipal wells tapping the aquifers. Some shallow domestic wells tap the alluvium upgradient of the tailings site, although these sometimes dry up. There are no residences within one mile downgradient of the site. Some residences 2.5 miles north of the site haul their water from 6 miles north. A residence three miles downgradient uses ground water for drinking water purposes. No existing water supplies appear to have been affected by the mill-tailings site.

\subsubsection{Risk Assessment}

Appendix $C$ presents compiled concentration data and risk estimates for this site. There are no samples for receptor wells in any of the three aquifers near the Monument Valley site.

In the maximally contaminated wells the concentrations of all pollutants exceeded detection limits, except for selenium which was not detected in any of the three aquifers. In general, chemical concentrations in the sampled wells increased in the following way; DeChelly, Shinarump and Alluvium.

Chronic/Subchronic Ratios and Drinking Water Standards - In the alluvial monitor wells, the AIS ratio of 1.0 was exceeded for arsenic (1.1), cadmium (2.6), nitrate (36) and vanadium 


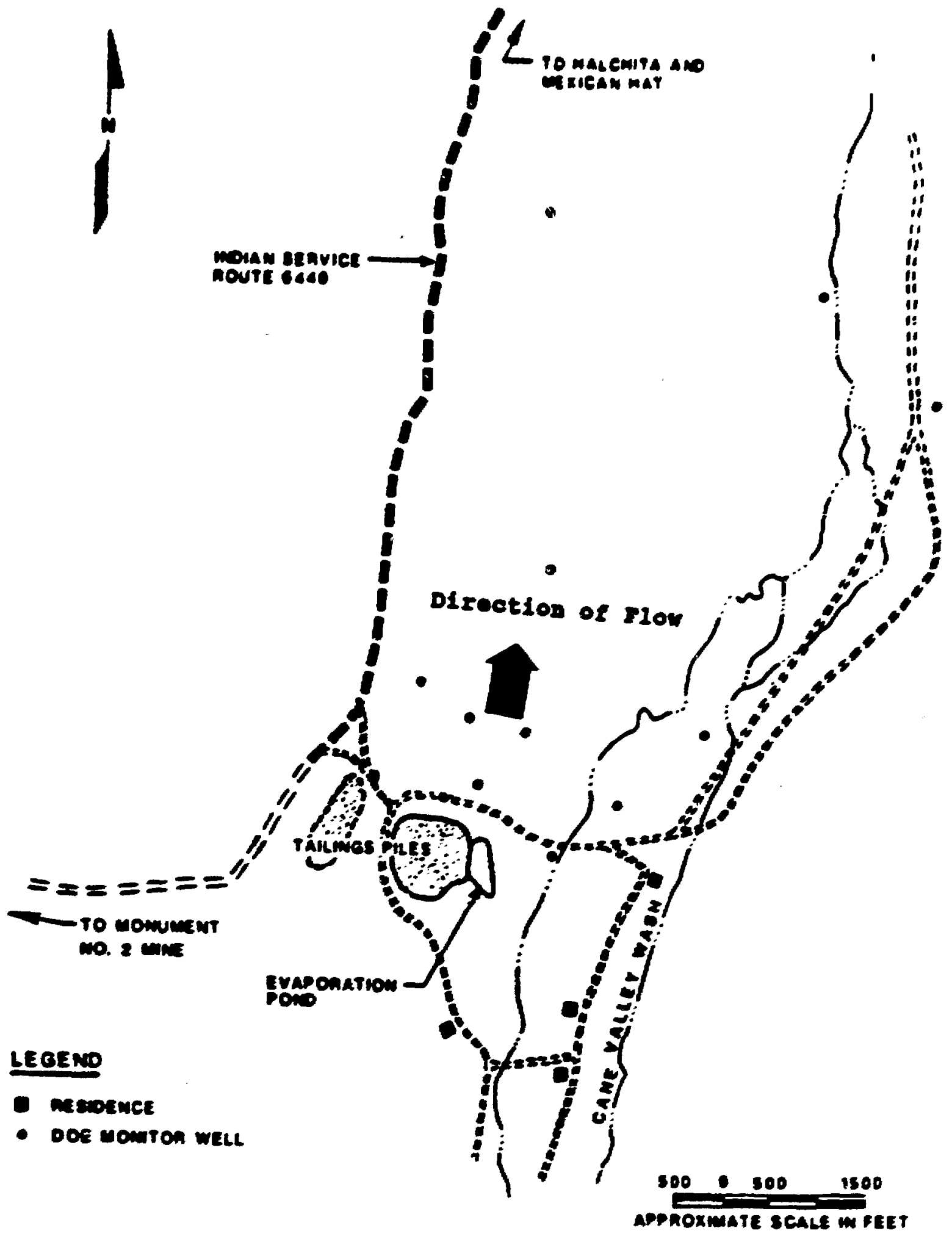

Figure 3. Mill-Tailings Site at Monument Valley, Arizona.

(Monitor Wels and Residences; modified from DOE, 1986) 
(8.0). AIC ratios were exceeded in the alluvium for arsenic (1.1), cadmium (11), molybdenum (12.1), nitrate (36), sulfate (7.4), uranium (2.0), and vanadium $(1.1)$.

Shinarump monitor wells exceeded the AIS ratios for vanadium (7.0) and the AIC ratio for cadmium (1.4), molybdenum (8.6), uranium (1.9) and vanadium (1.1). Monitor wells in the DeChelly aquifer exceeded the AIS ratio for vanadium (6.0), and the AIC ratio for molybdenum (9.0) and uranium (3.0). Subtraction of the minimum background concentrations measured for each aquifer dici not appreciably change the calculated ratios.

Drinking water standards were exceeded in the maximum alluvial monitoring wells for cadnium, chromium, molybdenum, nitrate, selenium and sulfate. Monitor wells in the Shinarump aquifer exceeded drinking water standards for chromium, molybdenum and sulfate. Drinking water standards were exceeded for chromium, molybdenum and uranium in DeChelly monitor wells.

Cancer Risk - A lifetime risk estimate of $1 \times 10^{-6}$ was exceeded in the alluvium at Monument Valley for arsenic $\left(6.86 \times 10^{-3}\right)$, lead-210 $\left(5.9 \times 10^{-5}\right.$, ICRP), polonium-210 $(2.0 \times$ $\left.10^{-5}\right)$, radium $226+228\left(1.7 \times 10^{-5}\right)$, thorium-230 $\left(2.7 \times 10^{-6}\right.$, ICRP), and uranium $\left(3.7 \times 10^{-}\right.$ 5 ,ICRP). A $1 \times 10^{-5}$ risk level was exceeded for arsenic, lead-210, polonium-210, radium $226+228$ and uranium. No contaminants in alluvial monitor wells exceeded risk estimates based on drinking water standards.

In monitor wells screened in the Shinarump aquifer, the $1 \times 10^{-6}$ risk level was exceeded for arsenic $\left(2.1 \times 10^{-3}\right)$, lead-210 (9.1 $\times 10^{-5}$, ICRP), polonium-210 $\left(3.2 \times 10^{-6}\right)$, thorium-230 $\left(3.7 \times 10^{-6}\right.$, ICRP) and uranium $\left(3.4 \times 10^{-5}\right.$, ICRP). A $1 \times 10^{-5}$ risk level was exceeded for arsenic, lead-210, radium $226 \& 228$ and uranium. None of the risk estimates based on drinking water standards are exceeded in maximally contaminated monitor wells in the Shinarump aquifer.

A risk level of $1 \times 10^{-6}$ is exceeded for monitor wells tapping the DeChelly aquifer for arsenic $\left(8.6 \times 10^{-4}\right)$, lead-2 $10\left(5.5 \times 10^{-5}\right.$, ICRP), polonium-210 $\left(4.2 \times 10^{-6}\right)$, radium $226+228(1.3$ $\left.\times 10^{-5}\right)$, thorium-230 $\left(1.7 \times 10^{-6}, \mathrm{ICRP}\right)$ and uranium $\left(5.5 \times 10^{-5}\right.$, ICRP). A I $\times 10^{-5}$ risk level is exceeded for arsenic, lead-210, radium $226+228$ and uranium. Risk estimates based on drinking water standards are exceeded for uranium in DeChelly monitor wells.

Subtraction of minimum background concentrations in each aquifer did not change the risk estimates.

\subsubsection{Summary}

Contaminants exceeding the ratio of 1.0 for AIS and AIC's ardior the $1 \times 10^{-6}$ risk level for cancer include: arsenic, cadmium, molybdenum, nitrate, sulfate, uranium, vanadium, lead-210, polonium-210, radium $226+228$ and thorium-230 in the alluvium; cadimium, molybdenum, uranium, varadium, arsenic, lead-210, polonium-210, radium $226+228$ and thorium-230 in the 
Shinarump; and molybdenum, uranium, vanadium, arsenic, lead-210, polonium-210, radium $226+228$ and thorium-230 in the DeChelly.

For chronic and subchronic effects, contaminants flagged as exceeding both the drinking water standard and the 1.0 AIS or AIC ratio include cadmium, molybdenum, nitrate and sulfate in the alluvium, molybdenum in the Shinarump, and molybdenum and uranium in the DeChelly. For cancer risk, uranium in the maximally contaminated alluvial and DeChelly monitor wells exceeded both the $1 \times 10^{-6}$ risk level and the risk level based on drinking water standards.

The tailings pile at Monument Valley has created a defined plume of nitrate, sulfate and uranium in the alluvial system. Other contaminants detected in alluvial monitor wells may be coming from the tailings pile, but the distribution of concentrations in background and impacted wells must be considered in order to develop a reasonable exposure estimate. A number of the contaminants flagged using this approach may not show exceedances when more realistic background concentrations are used in the analyses.

For the most part, the Shinarump and DeChelly aquifers have not been affected by the mill-tailings site. The elevated concentrations which cause the exceedances described above are in one or a few wells in the Shinarump and DeChelly, and do not reflect the general water quality in the deeper aquifers.

There are no municipal wells near Monument Valley. There are several shallow domestic wells upgradient of the site, and one three miles downgradient. No receptor wells were affected by the mill-tailings pile at Monument Valley.

\subsection{Riverton, Wyoming}

\subsubsection{Ground Water Geology, Flow and Water Quality}

Ground water in the Riverton area (Figure 4) is under unconfined and confined conditions. The unconfined system is in alluvial deposits and the uppermost sandstone beds of the Wind River Formation. The confined system is in the deeper sandstone beds of the Wind River Formation.

The flow direction in the alluvium is predominantly south to east, toward the Little Wind River. The local gradient in the confined system appears to correspond to that in the unconfined system.

The extent to which the unconfined and confined aquifers are hydraulically connected is not clear. In general, interbedded shale, siltstone and claystone confine the ground water in the sandstone beds and tend to restrict contaminant migration. There is, however, a downward vertical hydraulic gradient indicating the potential for downward flow. 


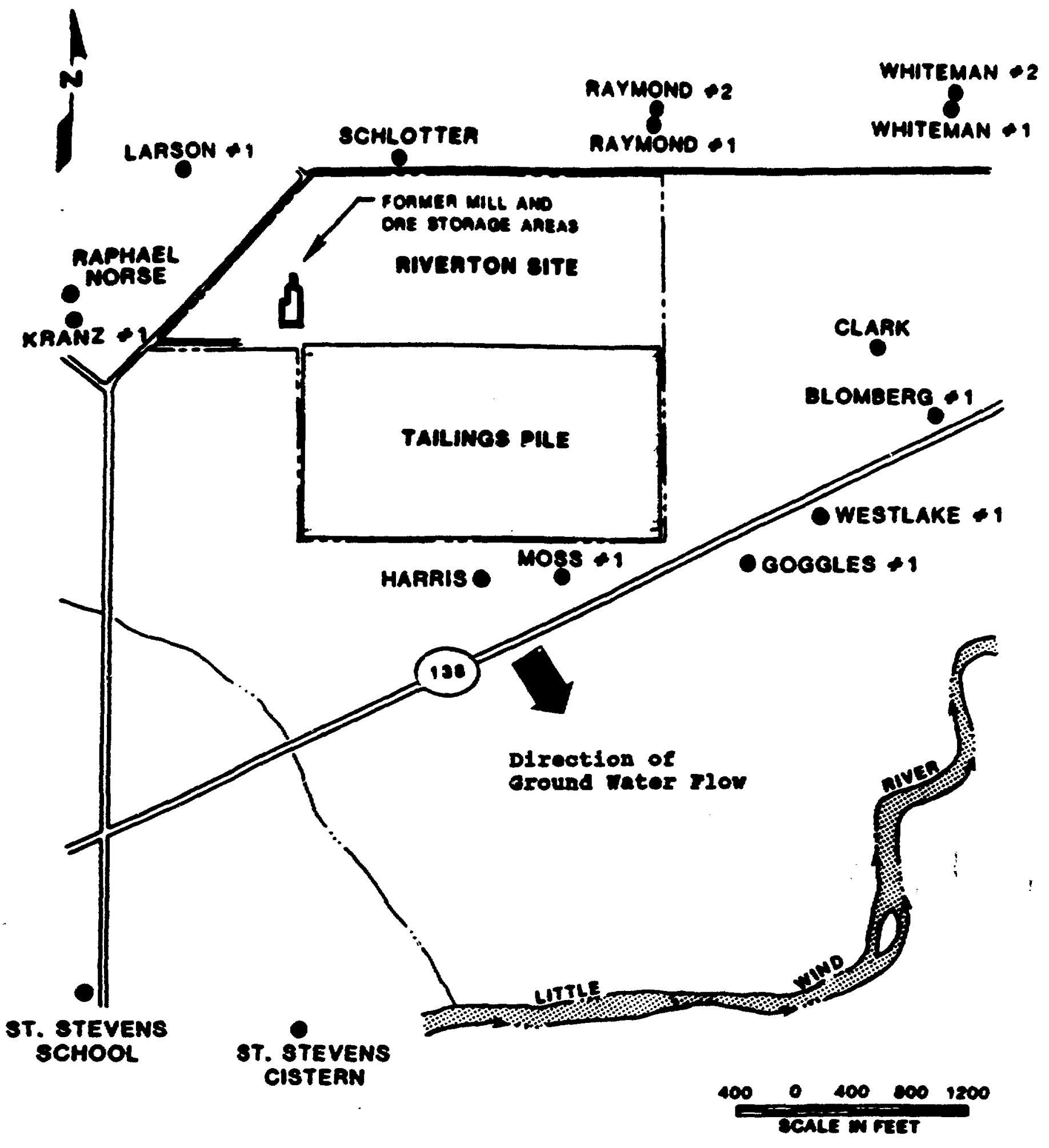

Figure 4. Mill-Tailings Site at Riverton, Wyoming

(Domestic Wells Sampled by DOE; modified from DOE, 1987) 
Sulfate, molybdenum, uranium and other contaminants have moved from the tailings pile into the unconfined aquifer. There is also some evidence that the confined aquifer has been contaminated by water in the unconfined system. Contamination from the tailings pile is, however, largely restricted to the unconfined aquifer.

\subsubsection{Water Use}

Ground water from the unconfined aquifer is not the primary source for domestic, municipal or industrial use in the area because of poor quality and low quantity. Development of the unconfined aquifer is limited to areas upgradient of the site, and the water is used for irrigation and stock watering.

Because the unconfined aquifer has limited use the data used in this assessment is from monitoring wells only. No data are available for actual uses of the unconfined aquifer downgradient of the tailings pile.

The confined aquifer is the primary source of water in the Riverton area. There are a number of domestic wells downgradient of the mill-tailings site, and available data from these domestic wells are included in this assessment.

\subsubsection{Risk Assessment}

Appendix $\mathrm{C}$ gives the compiled concentration data and risk estimates for this site. In the monitor and receptor wells measured concentrations of all chemicals, except for cadmium in the confined receptor wells, exceeded the detection limits. In contrast, only lead, sulfate and thorium were measured in detectable concentrations in the confined background wells. Similarly, all chemicals, except chromium, were present in the maximum unconfined background wells.

Chronic/Subchronic Ratios and Drinking Water Standards - In the unconfined monitor wells, the AIS ratio of 1.0 was exceeded for selenium (1.1) and arsenic (1.4). AIC ratios were exceeded in maximum unconfined monitor wells for arsenic (1.4), cadmium (2.2), molybdenum (27.6), sulfate (15.0), selenium (1.2) and uranium (135.3).

In the confined aquifer, no monitor or receptor wells exceed the AIS ratio of 1.0 for any contaminant. Maximum confined monitors exceed the AIC ratio for molybdenum (5.5) and sulfate (3.3). Confined receptor wells exceed the AIC ratio for molybdenum (1.4), sulfate (1.7) and uranium (13.9).

Drinking water standards were exceeded in unconfined monitor wells for molybdenum, selenium, sulfate and uranium. Confined monitors exceeded drinking water standards for molybdenum, selenium and sulfate. Confined receptor wells exceeded drinking water standards for sulfate and uranium. Again, the risk estimates do not change in any large way from the addition or subtraction of the minimum background concentrations. 
Cancer Risk - Maximally contaminated monitor wells screened in the unconfined aquifer at Riverton exceeded the $1 \times 10^{-6}$ risk level for arsenic $\left(8.6 \times 10^{-3}\right)$, lead-210 $\left(6.5 \times 10^{-5}\right.$, ICRP), radium $226+228\left(1.8 \times 10^{-6}\right)$, thorium-230 $\left(4.4 \times 10^{-5}\right.$, ICRP) and uranium $\left(2.6 \times 10^{-3}\right.$, ICRP). $A$ $1 \times 10^{-5}$ risk level is exceeded for arsenic, lead-210, thorium-230 and uranium. In unconfined monitor wells risk levels based on drinking water standards are exceeded only for uranium.

In monitor wells tapping the confined aquifer at Riverton, the $1 \times 10^{-6}$ risk level is exceeded for arsenic $\left(2.6 \times 10^{-3}\right)$, lead-210 $\left(3.9 \times 10^{-5}\right.$, ICRP), radium $226+228\left(1.5 \times 10^{-5}\right)$ and uranium $\left(7.1 \times 10^{-6}\right.$, ICRP). The $1 \times 10^{-5}$ risk level is exceeded for arsenic, lead-210, and radium $226+228$. In confined monitor wells none of the contaminants exceed risk levels based on drinking water standards.

Confined receptor wells exceed the $1 \times 10^{-6}$ risk level for lead-210 (5.9 $\left.\times 10^{-5}, 1 C R P\right)$, radium $226+228\left(1.1 \times 10^{-5}\right)$ and uranium $\left(2.5 \times 10^{-4}\right.$, ICRP). The $1 \times 10^{-5}$ risk level is exceeded for lead-210, radium $226+228$ and uranium. In confined monitor wells uranium exceeded risk levels based on drinking water standards.

\subsubsection{Summary}

Contaminants exceeding the recommended ratio of 1.0 for chronic and or subchronic effects, and/or the $1 \times 10^{-6}$ lifetime risk level for cancer include arsenic, cadmium, molybdenum, sulfate, selenium, uranium, lead-210, radium 226+228 and thorium-230 in unconfined monitor wells; molybdenum, sulfate, arsenic, lead-210, radium $226+228$ and uranium in confined monitors, and molybdenum, sulfate, uranium, lead-210 and radium $226+228$ in confined receptors.

For chronic and subchronic effects, contaminants which exceeded both the drinking water standard and the 1.0 ratio include molybdenum, selenium, sulfate and uranium in unconfined monitors, molybdenum and sulfate in confined monitors, and uranium and sulfate in confined receptors. For cancer risk, the $1 \times 10^{-6}$ risk level and the risk level based on drinking water standards were exceeded for uranium in unconfined monitor wells and confined receptors.

The tailings pile at Riverton has created plumes of uranium, molybdenum and sulfate in the unconfined system. There is also evidence of contamination in some confined wells. Other contaminants also show exceedances in wells in both aquifers, and these elevated concentrations may be caused by the pile. Some of the contaminants flagged in this conservative assessment may not be of concern when a more detailed analysis of background concentrations is performed.

The unconfined aquifer has been contaminated by the tailings pile. There is limited use of the upper, unconfined aquifer at Riverton, and no receptor wells were sampled. The confined aquifer is largely unaffected. A receptor well in the confined aquifer shows exceedances for several contaminants, but this well may draw water from the unconfined and confined aquifers. 


\section{DISCUSSION}

Tables 2 - 4 summarize "Maximum Estimated Subchronic Health Risks", "Maximum Estimated Chronic Health Risks" and the "Maximum Estimated Cancer Risks" for all sites, chemicals, and wells (monitor and receptor). In interpreting these data, one must keep in mind the conservative assumptions on which they are based.

The first conservatism is in the exposure assessment. Ideally, actual concentrations and sources of each contaminant would be known for each aquifer and well used for drinking water. Surrounding each tailings site are several monitoring and background wells. To estimate contributions of the mill-tailings site to contaminant levels in monitoring wells, concentrations of each contaminant in the background ground water must be subtracted from the concentration of that contaminant in downgradient monitoring wells. There is a wide distribution of concentrations for each contaminant.

In this analysis a worst case estimate of exposure was developed for each contaminant at each site. The maximum concentration detected in monitor and receptor wells for each contaminant was used. Use of the maximum value is conservative because most ground water welis have lower concentrations. Using monitor wells is conservative because they are deliberately placed to intercept contaminated water, are usually closer to the site, and are of ten screened at shallower depths than receptor wells.

The analysis also took the conservative path of maximizing the calculated net contribution of the piles to ground water by subtracting the lowest background well measurement from the highest receptor or monitor well measurement. The difference between upgradient and downgradient wells is only a crude estimate of the contribution of the mill-tailings in any event. In some cases, there are factors which clearly distort downgradient-upgradient differences, e.g., the geothermal water high in arsenic and sulfate at Lakeview, Oregon. Even where downgradientupgradient differences represent a reasonable way to estimate the contribution of the tailings piles, this conservative method of calculation clearly overestimates exposure. In fact, since the lower limit of detection varies among measurements, there are of ten measurements below the limit of detection, conservatively taken as zero. Thus, the net exposure is virtually always equal to the gross exposure.

The cose-response process also includes several conservatisms. In constructing an algorithm to predict the response of human populations to various levels of contaminants, clinical, controlled experimental, and epidemiological data describing the response of humans to the concentrations to which they are expected to be exposed would ideally be available. Such 
Table 2. Maximum Estimated Subchronic Ratios ${ }^{1}$

\begin{tabular}{|c|c|c|c|c|c|c|c|c|c|}
\hline Site/Aquifer & As & $C d$ & $\mathrm{Cr}$ & Mo & No3 & Se & SO4 & $\mathrm{U}$ & v \\
\hline $\begin{array}{l}\text { Gunnison, CO } \\
\text { Monitor/Alluvial } \\
\text { Receptor/Alluvial }\end{array}$ & $\begin{array}{r}2.9 \\
0\end{array}$ & $\begin{array}{l}0 \\
0\end{array}$ & $\begin{array}{l}0 \\
0\end{array}$ & $\begin{array}{l}\text { NA } \\
\text { NA }\end{array}$ & $\begin{array}{l}0.8 \\
0.1\end{array}$ & $0.2^{*}$ & $\begin{array}{l}N A^{*} \\
N A\end{array}$ & $\begin{array}{l}\mathrm{NA}^{*} \\
\mathrm{NA}^{*}\end{array}$ & $\begin{array}{r}0 \\
0.1\end{array}$ \\
\hline $\begin{array}{l}\text { Lakeview, OR } \\
\text { Monitor/Shallow } \\
\text { Receptor/Shallow } \\
\text { Monitor/Deep } \\
\text { Receptor/Deep }\end{array}$ & $\begin{array}{l}7.1^{*} \\
-. \\
1.4 \\
0.8\end{array}$ & $\begin{array}{l}2.6^{*} \\
-- \\
0.5 \\
0\end{array}$ & $\begin{array}{r}0 \\
- \\
0.1 \\
0\end{array}$ & $\begin{array}{l}\text { NA* } \\
-- \\
\text { NA } \\
\text { NA }\end{array}$ & $\begin{array}{l}0.4 \\
- \\
0 \\
0.1\end{array}$ & $\begin{array}{c}0 \\
- \\
0 \\
0\end{array}$ & $\begin{array}{l}\mathrm{NA}^{*} \\
- \\
\mathrm{NA} \\
\mathrm{NA}\end{array}$ & $\begin{array}{l}\text { NA } \\
-- \\
\text { NA } \\
\text { NA }\end{array}$ & $\begin{array}{r}0.2 \\
-- \\
0 \\
0.4\end{array}$ \\
\hline $\begin{array}{l}\text { Monunent Valley, AZ } \\
\text { Monitor/Alluvial }\end{array}$ & 1.1 & $2.6^{*}$ & $0.1^{*}$ & $\mathrm{NA}^{*}$ & $36.4^{*}$ & $0.1^{*}$ & $\mathrm{NA}^{*}$ & NA & 8 \\
\hline $\begin{array}{l}\text { Receptor/Alluvial } \\
\text { Monitor/Shinarump }\end{array}$ & $\ddot{0.4}$ & $\overline{0.3}$ & $\overline{0.1}$ * & $\overline{\mathrm{NA}} *$ & 0.9 & $\cdots$ & & $\ddot{N A}$ & $7^{--}$ \\
\hline $\begin{array}{l}\text { Receptor/Shinarump } \\
\text { Monitor/DeChelly }\end{array}$ & $\overline{0.1}$ & 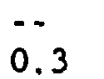 & $0.1^{*}$ & $\mathrm{NA}^{*}$ & $\overline{0.2}$ & -- & $\mathrm{NA}^{*}$ & $\overline{N A}$ & $6^{\cdots}$ \\
\hline Receptor/DeChelly & $\cdots$ & $\cdots$ & - & $\cdots$ & - & -- & - & $\cdots$ & -- \\
\hline $\begin{array}{l}\text { Riverton, WY } \\
\text { Monitor/Unconfined } \\
\text { Receptor/Unconfined } \\
\text { Monitor/Confined } \\
\text { Receptor/Confined }\end{array}$ & $\begin{array}{l}1.4 \\
-- \\
0.4 \\
0\end{array}$ & $\begin{array}{r}0.5 \\
-. \\
0 \\
0\end{array}$ & $\begin{array}{r}0 \\
-- \\
0 \\
0\end{array}$ & $\begin{array}{l}\mathrm{NA}^{*} \\
\mathrm{NA} \\
\mathrm{NA}\end{array}$ & $\begin{array}{l}0.2 \\
=- \\
0.7 \\
0.5\end{array}$ & ${ }_{0.1^{*}}^{1.1^{*}}$ & $\begin{array}{l}\mathrm{NA}^{*} \\
-- \\
\mathrm{NA}^{*} \\
\mathrm{NA}^{*}\end{array}$ & $\begin{array}{l}\mathrm{NA}^{*} \\
\cdots \\
\mathrm{NA} \\
\mathrm{NA}^{*}\end{array}$ & $\begin{array}{r}0.1 \\
-. \\
0.6 \\
0\end{array}$ \\
\hline
\end{tabular}

Ratios in bold exceed 1.0

NA Not applicable

- No sample

* Drinking water standard exceeded 
Table 3. Maximum Estimated Chronic Ratios ${ }^{1}$

\section{Site/Aquifer}

As

cd

Cr

2.9

0

0

0.1

0

0.1

0.8

Receptor/Alluvial

$7.1^{*} 10.7^{*}$

0.2

$6.2^{*}$

0.3

$-\cdot$

$1.4 \quad 2.1$

0.8

0.3

0

1.4

Receptor/Deep

Monument Valley, AZ

Monitor/Alluvial

Receptor/Alluvial

Monitor/Shinarump

Receptor/Shinarump

Monitor/DeChelly

Receptor/DeChelly

Riverton, WY

Monitor/Unconfined

Receptor/Unconfined

Monitor/Confined

Receptor/Confined

$1.1 \quad 10.7^{*}$

$0.5^{*}$

$12.1^{\star}$

$0.4^{*}$

$0.4 \quad 1.4$

--

0.1

$-\cdot$

1

$0.3^{*}$

- -

1.4

2.2

0.2

-.

0.2

0

0.4

0

NO3

$\mathrm{Se}$

S04

u

V

1 Ratios in bold exceed 1.0

- No sample

*

Drinking water standard exceeded 
Table 4. Maximum Estimated Cancer Risks ${ }^{1}$

\begin{tabular}{|c|c|c|c|c|c|c|}
\hline Site/Aquifer & As & $\mathrm{Pb}-210$ & Po- 210 & Ra $226 \& 228$ & Th -230 & $\mathbf{U}$ \\
\hline $\begin{array}{l}\text { Gunnison, CO } \\
\text { Monitor/Alluvial } \\
\text { Receptor/Alluvial }\end{array}$ & $\begin{array}{c}1.7 \mathrm{E}-02 \\
--\end{array}$ & $\begin{array}{l}0.0 \mathrm{E}+00 \\
1.1 \mathrm{E}-04\end{array}$ & $\begin{array}{l}- \\
-\end{array}$ & $\begin{array}{l}3.6 \mathrm{E}-05 \\
4.4 \mathrm{E}-06\end{array}$ & $\begin{array}{l}0.0 \mathrm{E}+00 \\
3.0 \mathrm{E}-06\end{array}$ & $\begin{array}{l}7.4 \mathrm{E}-05^{*} \\
1.3 \mathrm{E}-04^{*}\end{array}$ \\
\hline $\begin{array}{l}\text { Lakeview, OR } \\
\text { Monitor/Shallow } \\
\text { Receptor/Shallow } \\
\text { Monitor/Deep } \\
\text { Receptor/Deep }\end{array}$ & $\begin{array}{l}4.3 E-02^{*} \\
-- \\
8.6 E-03 \\
4.7 E-03\end{array}$ & $\begin{array}{l}0.0 \mathrm{E}+00 \\
\cdots \\
0.0 \mathrm{E}+00 \\
0.0 \mathrm{E}+00\end{array}$ & $\begin{array}{l}9.6 \mathrm{E}-05 \\
\cdots \\
4.6 \mathrm{E}-05 \\
0.0 \mathrm{E}+00\end{array}$ & $\begin{array}{l}2.3 E-05 \\
-- \\
2.3 E-05 \\
0.0 E+00\end{array}$ & $\begin{array}{l}5.4 E-06 \\
-- \\
1.1 E-05 \\
0.0 E+00\end{array}$ & $\begin{array}{l}3.2 \mathrm{E}-06 \\
-- \\
1.4 \mathrm{E}-06 \\
0.0 \mathrm{E}+00\end{array}$ \\
\hline $\begin{array}{l}\text { Monument Valley, AZ } \\
\text { Monitor/Alluvial } \\
\text { Receptor/Alluvial } \\
\text { Monitor/Shinarump } \\
\text { Receptor/Shinarump } \\
\text { Monitor/DeChelly } \\
\text { Receptor/DeChelly }\end{array}$ & $\begin{array}{l}6.9 \mathrm{E}-03 \\
\cdots \\
2.1 \mathrm{E}-03 \\
\cdots \\
8.6 \mathrm{E}-04 \\
\cdots\end{array}$ & $\begin{array}{l}5.9 \mathrm{E}-05 \\
-. \\
9.1 \mathrm{E}-05 \\
- \\
4.2 \mathrm{E}-06 \\
\cdots\end{array}$ & $\begin{array}{l}2.0 \mathrm{E}-05 \\
-- \\
3.2 \mathrm{E}-06 \\
-. \\
4.2 \mathrm{E}-06 \\
--\end{array}$ & $\begin{array}{l}1.7 \mathrm{E}-05 \\
-. \\
1.5 \mathrm{E}-05 \\
\cdots \\
1.3 \mathrm{E}-05 \\
\cdots\end{array}$ & $\begin{array}{l}2.7 E-06 \\
-. \\
3.7 E-06 \\
-- \\
1.7 E-06 \\
\cdots\end{array}$ & $\begin{array}{l}3.7 \mathrm{E}-05 \\
-- \\
3.4 \mathrm{E}-05 \\
-- \\
5.5 \mathrm{E}-05^{*} \\
--\end{array}$ \\
\hline $\begin{array}{l}\text { Riverton, WY } \\
\text { Monitor/Unconfined } \\
\text { Receptor/Unconfined } \\
\text { Monitor/Confined } \\
\text { Receptor/Confined }\end{array}$ & $\begin{array}{l}8.6 \mathrm{E}-03 \\
-. \\
2.6 \mathrm{E}-03 \\
0.0 \mathrm{E}+00\end{array}$ & $\begin{array}{l}6.5 E-05 \\
-. \\
3.9 E-05 \\
5.9 E-05\end{array}$ & $\begin{array}{l}\cdots \\
- \\
--\end{array}$ & $\begin{array}{l}1.8 \mathrm{E}-06 \\
-. \\
1.5 \mathrm{E}-05 \\
1.1 \mathrm{E}-05\end{array}$ & $\begin{array}{l}4.4 \mathrm{E}-05 \\
\cdots \\
6.7 \mathrm{E}-07 \\
1.4 \mathrm{E}-06\end{array}$ & $\begin{array}{l}2.5 E-03^{*} \\
-- \\
7: 1 E-06 \\
2.5 E-04^{*}\end{array}$ \\
\hline Calculated Risks ${ }^{2}$ & $2.1 E-02$ & $3.3 E-03$ & $7.4 \mathrm{E}-03$ & $3.9 \mathrm{E}-05$ & NA & $4.7 \mathrm{E}-05$ \\
\hline
\end{tabular}

1 Lifetime cancer risk, maximum of EPA and ICRP estimate

2 Risk estimates calculated using drinking water standards

* Exceeds risk estimates calculated using drinking water standards

- No sample

NA Not available 
information is rarely available; extrapolations to human health effects must of ten be based on limited data from animal studies.

It is important to discuss the method and implications of extrapolation from animal to man. This is done on the basis of rate of ingestion per unit body weight, i.e., (milligrams of chemical per day)/(kilogram body weight). This method of extrapolation is widely used in toxicology and medicine. There are disagreements over the precise scaling factor to be used. Some believe that the scaling factor should be in terms of body weight raised to the two-thirds power, for example. Whether this or simple body weight is the correct scaling factor cannot be determined in experiments comparing rats and mice, for example, but such a simple adjustment can make an order of magnitude difference when extrapolating from mouse to man. More importantly, advances made in the past decade in the science of pharmacokinetics enables these simple scaling factors to be replaced with physiologically based pharmacokinetic models when sufficient data are available. These take account of actual biological differences between two species in the metabolism and distribution of specific chemicals, substituting knowledge for arbitrary safety factors.

The AIS represents the highest human intake of a chemical that does not cause adverse effects in a short-term (10-90 days) exposure. The AIC represents the highest human intake of a chemical that does not cause adverse effects when exposure is long term, assumed to be chronic over a 70 year lifespan. The concept of an acceptable intake level is based on the assumption of a threshold effect. This is a commonly accepted biological theory; below a given dose level, a substance will have no effect on an individual, although this threshold level may vary among species and among individuals in the same species. The calculation of AIS and AIC values are designed to protect sensitive populations, with sensitivity depending on such diverse contaminantdependent factors as age, sex, co-exposure to other pollutants, etc.

Although some AIS values are based on human studies, most are derived from short- term (10-90 day) animal studies. With chemicals lacking appropriate human data, the highest subchronic exposure level among animals causing no adverse effects, the no observed adverse effects level (NOAEL) is used. To extrapolate the animal NOAEL to a human AIS level, the NOAEL is divided by a safety factor, usually 10. To account for the fact that two individuals of the same species may not respond similarly to an identical exposure to a given chemical, the NOAEL is divided by an additional factor of 10 . In general, an AIS is thus 100 times smaller than the highest concentration which had no observed adverse effect on animals. Thus, these calculations inherently assume that humans always are more responsive to chemicals than the studied animals.

For most chemicals, the AIC is also based on the NOAEL obtained from a survey of the animal toxicology literature. The chronic NOAEL is then reduced by the same two orders of 
magnitude as the AIS. For some chemicals, chronic studies are not available. In this situation the subchronic NOAEL is divided by a third safety factor of 10 to compensate for the use of subchronic data to derive a chronic indicator of dose-response. In this case the value of the Acceptable Intake for Chronic Exposure may simply be $1 / 1000$ of the highest no observable adverse effect level. Application of such safety factors in the absence of better data is conservative.

The risk characterization step compares exposure levels for each contaminant potentially derived from mill-tailings at each site in maximum concentration wells to acceptable limits (AIS or AIC). This risk characterization quotient is derived from two quantïties designed to be conservative. This ratio addresses the degree of safety, and does not quantify risk in terms of expected probability of disease. A ratio of 1.1 does not mean the water will cause harm to someone drinking it, only that the margin of safety has been slightly reduced.

For carcinogenesis, regulatory agencies reject the use of effects thresholds. Instead, it is assumed that the dose-response function passes through zero, i.e., that even an incrementally small dose may produce an effect. Risk is estimated from potency factors which, unlike the AIS and AIC, can be used to estimate risk in terms of increased probability of disease.

EPA Interim Drinking Water Regulations for radionuclides are not based on limiting risk below a given level. Rather maximum concentrations reflect what was achievable, considering cost and feasibility. The regulations limit annual excess cancer mortality risk to less than $1.0 \times 10^{-6}$ for each class of radionuclide (e.g., $\mathrm{Ra}-226+\mathrm{Ra}-226$, natural uranium). This translates to an lifetime excess risk of about $7.0 \times 10^{-5}$ for lifetime exposure at drinking water concentration standards. For example, the limit for man-made beta- and gamma-ray emitters in the Interim Drinking Water Standards is $4 \mathrm{mrem} / \mathrm{y}$. If 285 excess cancer deaths per million rem is assumed, the excess lifetime risk will be $1.14 \times 10^{-6}$ for one year of exposure averaged over the population, or $0.8 \times 10^{-5}$ for a lifetime of exposure. This agrees with EPA's own calculation. Another example is the $5 \mathrm{pCi} / 1$ limit for $\mathrm{Ra}-226$ and/or $\mathrm{Ra}-228$. The lifetime excess risk for lifetime ingestion of $2 \mathrm{l} /$ day at a concentration of $1 \mathrm{pCi} / \mathrm{l}$ is given by EPA as $8.8 \times 10^{-6}$ and $6.6 \times 10^{-6}$ for $\mathrm{Ra}-226$ and $\mathrm{Ra}-228$. The annual risk for $5 \mathrm{pCi} / \mathrm{l}$ is then about $0.55 \times 10^{-6}$.

\section{CONCLUSIONS}

The procedure used in this study was that outlined by the EPA in the Superfund Public Health Evaluation Manual. By its nature this approach overestimates the actual health risks. Because of the highly conservative assumptions used in the estimates of acceptable limits and potency factors, and with the highly conservative assumptions used in estimating dose, one may be 
confident that contaminants which not present potential health risks in this screening analysis may be disregarded in future health risk evaluation for the studied UMTRA sites. On the other hand, chemicals identified in this screening analysis as presenting potential health risks may, in fact, be at levels that are still quite safe. Refined dose-response functions, exposure estimates, and demographic distributions are needed to analyze the potential health risks contributed by the contaminants which were not eliminated in this screening study.

\section{RECOMMENDATIONS}

Analyses conducted to-date are similar to those that would conducted by EPA. As noted, we consider this to be a screening-level analysis. Items identified in this initial screening step will undergo more detailed analysis to determine the accuracy of the calculated risk estimates and the benefits of different remediation options. Some approaches for evaluating the accuracy of the risk estimates are presented below.

Exposure Estimation - Current exposure estimates are based on the single highest reported concentration value in the receptor and monitor wells. Characterization of upgradient and downgradient pollutant concentrations can best be done by examining the full distribution of measurements, rather than their maximum or mean values. For each pollutant-aquifer combination which was calculated to pose a potential hazard, and for which no additional confounding sources are present that would invalidate an downgradient-upgradient difference as an estimate of the effect of the tailings pile, the full data set of measurements at each well should be determined. Wells within each class (background, monitoring, and receptor) should be grouped as necessary to form homogeneous groupings from which the groundwater pollutant concentrations for a specific geographical area can be characterized as a combined distribution. Exposure estimates will be developed differently for contaminants in a defined plume (often sulfate and uranium), and those not present in such an easily discernable pattern. The downgradientupgradient difference can then be characterized as the difference of two or more distributions, using Monte Carlo or Latin Hypercube sampling techniques. This should allow the potential exposure (gross and net) to be estimated probabilistically. The results may then be expressed as a best estimate with an uncertainty range which is independent of any $a$ priori assumptions of distribution, or as "conservative" estimates with any desired degree of conservatism.

In characterizing the distributions, special attention should be given to measurements that are below the limits of detection (LOD). The sensitivity of the results to these measurements can be determined by using selected case examples to make the calculation substituting either zero, half the LOD, or the LOD value itself as the mensurement. 
Dose-Response Estimation - Current critical toxicity values, are the for the most part, based on drinking water standards. The basis for these standards will be examined for excessive conservatism; and the uncertainty of the dose-response function estimated and combined with that of the exposure estimates. Alternative standards (e.g., World Health Organization Guidelines) will be identified and examined to determine their impacts on the critical values. All of the contaminants flagged as having potentially hazardous concentrations should be critically reviewed. As an example, a critical review of the EPA and ICRP cancer risk models used for setting drinking water concentration standards is presented in Appendix $D$.

Since carcinogen effects are estimated directly in increased risk, risk estimates from exposure to multiple carcinogens are considered additive; i.e., total risk $=$ risk from chemical $1+$ risk from chemical 2. This is an oversimplification; the actual combined effect will depend on the target organs of each carcinogen, the degree of interaction in metabolism and pharmacokinetics, the mechanism of carcinogenic effect, and the shape of the dose-response function. In most cases, too little will be known to carry this analysis of interaction very far, but some insights into the appropriateness of simply adding the risks may be gained from a review of the characteristics of the two contaminants and their interactions.

Noncarcinogen effects are based on threshold assumptions and expressed, not in quantitative risk, but in a ratio of exposure relative to a reference exposure level which includes safety factors. For noncarcinogens, the Manual recommends two steps: (1) simply add the intake ratios; if the result exceeds one there may be concern for a potential health risk. [Cumulative ratio $=[($ intake of chemical 1$) / A I C 1]+[($ intake of chemical 2$) / A I C 2]+\ldots$ The different pollutants, however, may affect entirely different organ systems. Adding an exposure to a chemical which produces gastro-intestinal disease to an exposure to a teratogen adds to the overall kinds of potential effects possible, but if each is below the threshold of effect, no effect ever occurs. The additional exposure does not reduce the margin of safety for teratogenic effects at all, nor does the teratogen reduce the margin of safety for the gastrointestional effects. The second step recommended by the EPA manual, then, is to do the addition separately for each class of effect. A hazard potential is deemed to exist, then, if any one of the combined ratios exceeds one. Beyond this, however, other methods of combination might be considered instead of the simple addition of ratios, or additional biological information concerning the action of each contaminant in generating each class of effect might be considered in a more sophisticated model. 


\section{REFERENCES}

Agency for Toxic Substances and Disease Registry, draft. Health Assessment Format, Guidelines and Methodology, U.S. Public Health Service, Atlanta, GA.

ICRP, 1977. International Commission on Radiological Protection, Recommendations of the International Commission on Radiological Protection, ICRP Publication 26, Annals of the ICRP, Vol. 1, No. 3, 1977.

ICRP, 1979. International Commission on Radiological Protection, Limits for Intakes of Radionuclides by Workers, ICRP Publication 30, Annals of the ICRP, Vol. 2, No. 3/4, 1979 , et seq.

U.S. Environmental Protection Agency. 1986a. Superfund Public Health Evaluation Manual. Washington, D.C.. EPA 540/1-86/060 (October, 1986).

U.S. Environmental Protection Agency. 1986b. Water Pollution Control; National rrimary Drinking . Water Regulations; Radionuclides; Federal Register Vol 51, No.189, pp34836-34862, September $30,1986$.

U.S. Department of Energy, 1987. Environmental Assessment- Remedial Action at the Riverton Uranium Mill-tailings Site, Riverton, Wyoming. June, 1987. DOE/EA-0254

U.S. Department of Energy, 1986. Remedial Action Plan for Stabilization of the Inactive Milltailings Site at Monument Valley, Arizona. February, 1986.

U.S. Department of Energy, 1985. Environmental Assessment of Remedial Action at the Lakeview Uranium Mill-tailings Site, Lakeview, Oregon. April, 1985. UMTRA-DOE/EA-0271, Volumes I,II.

U.S. Department of Energy, 1984. Environmental Assessment of Remedial Action at the Gunnison Uranium Mill-tailings Site, Gunnison, Colorado. December, 1984. Volumes I,II. 
APPENDIX A - Derivation ofDose-Response Coefficients: Acceptable Intake for Subchronic Exposure (AIS), the Acceptable Intake for Chronic Exposure (AIC), and Carcinogenic Potency Factor 


\section{SULFATE}

Based on aesthetic effects, the current EPA secondary drinking water standard for sulfate is $250 \mathrm{mg} / \mathrm{l}$. The World Health Organization has recommended a guideline level of sulfate in drinking water of $400 \mathrm{mg} / \mathrm{l}$ based on taste. Because of insufficient toxicology data, an Adjusted Acceptable Daily Intake (AADI) has not been calculated for sulfate. Likewise, primary drinking water regulations will not be promulgated by EPA at this time due to insufficient data on which to set a level for health protection.

In both animals and humans, soluble sulfate salts are absorbed from the intestine. Large doses are incompletely absorbed, have a cathartic effect and are continuously excreted in the urine. Diarrhea and dehydration are the only adverse health effects noted from exposure to high sulfate concentrations, and infants appear to be a more sensitive population than adults. Case histories which suggest that these adverse effects occur when infants consume formula made with well water containing more than $400-500 \mathrm{mg}$ sulfate per liter of water have resulted in a guidance level of $400 \mathrm{mg} / \mathrm{l}$ sulfate for the protection of infants (USEPA, 1985).

An acceptable intake for chronic exposure (AIC) to sulfate in drinking water of 40 $\mathrm{mg} / \mathrm{kg} /$ day was determined following the algorithms and examples for lead detailed in USEPA, 1986. The algorithm used to calculate the sulfate AIC is based on the $400 \mathrm{mg} / 1$ guidance level for infants (USEPA, 1985) and consumption of 1.0 liter water per day (NAS, 1977) by a standard 10 kg child (ICRP, J975):

$A I C=$ Guidance Level $\times 1$ l/day / 10 kg;

$\mathrm{AIC}=400 . \mathrm{mg} / 1 \times 1 \mathrm{l} /$ day $/ 10 \mathrm{~kg}$;

$A I C=40 . \mathrm{mg} / \mathrm{kg} /$ day for sulfate in drinking water. 


\section{REFERENCES}

International Commission on Radiological Protection (ICRP). 1975. Report of the Task Group on Reference Man. New York: Pergammon Press.

National Academy of Science (NAS). 1977. Drinking Water and Health. NRC Press.

U.S. Environmental Protection Agency. 1985. National Primary Drinking Water Regulations; Synthetic Organic Chemicals. Inorganic Chemicals and Microorganisms; Proposed Rules. 50 FR 46936-47022 (Nov 13, 1985).

U.S. Environmental Protection Agency. 1986. Superfund Public Health Evaluation Manual. Washington, D.C.. EPA 540/1-86/060 (October, 1986). 


\section{MOLYBDENUM}

An acceptable intake for chronic exposure (AIC) to molybdenum in drinking water of $0.0029 \mathrm{mg} / \mathrm{kg} /$ day was determined following the algorithms and examples for lead detailed in USEPA, 1986. For lead, the basis of the AIC calculation was the lead drinking water standard. Although a drinking water standard has not yet been proposed for molybdenum, a health advisory is currently under preparation (USEPA, 1985). EPA has, however, proposed a standard for molybdenum in ground water at uranium mill-tailing sites of $0.10 \mathrm{mg} / \mathrm{l}$ (USEPA, 1987) which is identical with the provisional Adjusted Acceptable Daily Intake (AADI) for molybdenum in drinking water developed by EPA under the Safe Drinking Water Act (USEPA, 1985). The proposed AADI is based on a human study (Chappell et al., 1979) in three communities (Denver, Breckenridge and Frisco) in which levels of plasma molybdenum remained within the normal range (5-34 ug Mo/l) among subjects consuming water not exceeding $0.2 \mathrm{mg} \mathrm{Mo/l}$. The provisional AADI was determined by using the $0.2 \mathrm{mg} / \mathrm{l}$ as a no adverse effects level (NOAEL) and applying an uncertainty factor of 2 , based on a human study with no noted adverse effects and consumption of 2 l/day. The authors of the report (Chappell et al., 1979) recommended a more conservative guideline of $0.05 \mathrm{mg} / \mathrm{l}$. The algorithm used to calculate the nolybdenum AIC assumed consumption of 2 liters water per day by a standard $70 \mathrm{~kg}$ man:

\footnotetext{
$A I C$ AADI $\times 21 /$ day / $70 \mathrm{~kg}$;

$A I C=0.10 \mathrm{mg} / 1 \times 2$ l, day $/ 70 \mathrm{~kg}$;

AIC $=0.0029 \mathrm{mg} / \mathrm{kg} /$ day for molybdenum in drinking water.
} 


\section{REFERENCES}

Chappell, W.R., R.R. Meglen, R. Moure-Eraso, C.C. Solomons, T.A. Tsongas, P.A. Walravens, and P.W. Winston. 1979. Human Health Effects of Molybdenum in Drinking Water. Cincinnati Ohio, EPA-600/1-79-006.

U.S. Environmental Protection Agency. 1985. National Primary Drinking Water Regulations; Synthetic Organic Chemicals, Inorganic Chemicals and Microorganisms; Proposed Rules. 50 FR 46936-47022 (Nov 13, 1985).

U.S. Environmental Protection Agency. 1986. Superfund Public Health Evaluation Manual. Washington, D.C.. EPA 540/1-86/060 (October, 1986).

U.S. Environmental Protection Agency. 1987. Standards for Remedial Actions at Inactive Uranium Processing Sites. 52 FR 36000-36008. (Sept 24, 1987). 


\section{VANADIUM}

The algorithms used for calculating the two values are shown below. A long term study by Schroeder, et al. (1976) reported that no "inherent toxicity" was found "in terms of growth, survival, longevity, life span or pathological changes" in mice fed approximately $0.5 \mathrm{mg} / \mathrm{kg} / \mathrm{day}$ vanadyl sulfate $(0.43 \mathrm{mg} / \mathrm{kg} /$ day) from weaning until natural death. This is the highest chronic exposure published to date. The first algorithm, which introduces an animal-to-human safety factor of 100 , generates the human AIC value of $0.005 \mathrm{mg} / \mathrm{kg} /$ day. This number agrees with a Soviet maximum intake limit based on a study done in 1961 (see Texicology of Trace Elements, p.177). That study found that the threshold chronic exposure of impairment of reflex response in mice was $0.05 \mathrm{mg} / \mathrm{kg} /$ day of vanadium pentoxide $\left(\mathrm{V}_{2} \mathrm{O}_{5}\right)$ or ammonium vanadate $\left(\mathrm{NH}_{4} \mathrm{VO}_{3}\right)$. A chronic exposure ( 6 months) of $0.005 \mathrm{mg} / \mathrm{kg} /$ day in mice did not result in "functional disturbances of conditioned reflex activities." This value was taken as the maximum permissible dose from drinking water in the Soviet Union.

The Acceptable Intake for Subchronic Exposure (AIS) is based on two short term (3 months) studies on rass (Domingo et al., 1985; Parker and Sharma, 1978). In both studies, rats were fed vanadium salts at 5 and $50 \mathrm{ppm}$ in drinking water. Neither study reported significant changes in body weight, organ weight, or hematocrit levels. However, each study reported vanadium accumulation in organs of rats fed $50 \mathrm{ppm}$, particularly in the kidneys, spleen, bones, and liver. No vanadium accumulation was noted for rats receiving $5 \mathrm{ppm}$ in their drinking water. Parker and Sharma (1978) showed that vanadium levels in all organs except bones deplete rapidly once oral administration has been stopped. Domingo et al.(1985) reported that there were mild histopathological changes in the kidneys, spleen, and lungs of rats fed sodium metavanadate $\left(\mathrm{NaVO}_{3}\right)$ at both 5 and $50 \mathrm{ppm}$, and that lesions on the organs were dose dependent. Based on these data, a water concentration of $5 \mathrm{ppm}$ was taken as the maximum subchronic exposure for rats. This concentration corresponds to a dose of $0.97 \mathrm{mg} / \mathrm{kg} / \mathrm{day}$. Adding in an animal-tohuman safety factor of 100 gives a human AIS of 0.0097 or $0.01 \mathrm{mg} / \mathrm{kg} /$ day.

$$
\text { .AlS } \quad \begin{aligned}
= & \text { AIS } \\
& =0.97 \mathrm{mg} / \mathrm{kg} / \text { day } / 100 \\
& =0.0097 \text { or } 0.1 \mathrm{mg} / \mathrm{kg} / \text { day }
\end{aligned}
$$




\section{REFERENCES}

Domingo, J.L., Llobet, J.M., Tomas, J.M. "Short-term Toxicity Studies of Vanadium in Rats." J. App. Tox. 5(6):418. 1985.

Parker, R.D.R., and Sharma, R.P. "Accumulation and Depletion of Vanadium in Selected Tissues of Rats Treated with Vanadyl Sulfate and Sodium Orthovanadate." J. Env. Patth. Tox. 2:235-45. 1978. 
APPENDIX B - Federal Standards for Selected Constituents. 
Appendix B. Federal Standards for Selected Constituents..

Reference

\begin{tabular}{lccc}
\hline Arsenic & $0.05 \mathrm{mg} / \mathrm{l}$ & 1 \\
Cadmium & $0.01 \mathrm{mg} / \mathrm{l}$ & 1 \\
Chromium & $0.05 \mathrm{mg} / 1$ & 1 \\
Molybdenum & $0.10 \mathrm{mg} / 1$ & 2 \\
Nitrate & $44.0^{\mathrm{a}} \mathrm{mg} / 1$ & 2 \\
Selenium & $0.01 \mathrm{mg} / 1$ & 1 \\
Sulfate & $250^{\mathrm{b}} \mathrm{mg} / 1$ & 3 \\
Uranium & $0.044 \mathrm{mg} / \mathrm{l}$ & 2 \\
Lead-210 & $100 \mathrm{pCi} / 1$ & 4 \\
Polonium-210 & $700 \mathrm{pCi} / 1$ & 4 \\
Radium-226 \& -228 & $5.0 \mathrm{pCi} / 1$ & 1 \\
\hline
\end{tabular}

a Nitrate as nitrate.

${ }^{b}$ Secondary drinking water standard - for contaminant concentration that primarily affect aesthetic qualities.

References:

1. 40 CFR 192.32(a) (Final Rule for Active Sites)

2. 52, FR 36007 (Proposed Rule for Inactive Sites)

3. 50 FR 46979 (Proposed Rule for Drinking WAter)

4. 10 CFR 20, Appendix B, Table II, Column 2 (NRC Final Rule on Permissible Concentrations 
APPENDIX C - Compiled Concentration Data, Ratios and Risk Estimates for Uranium Mill-tailings Sites 
2 stie mems: amisen, $\infty$, Altwiu

7 mecaured concentration - Receptor Hells

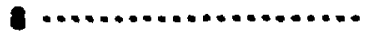

91

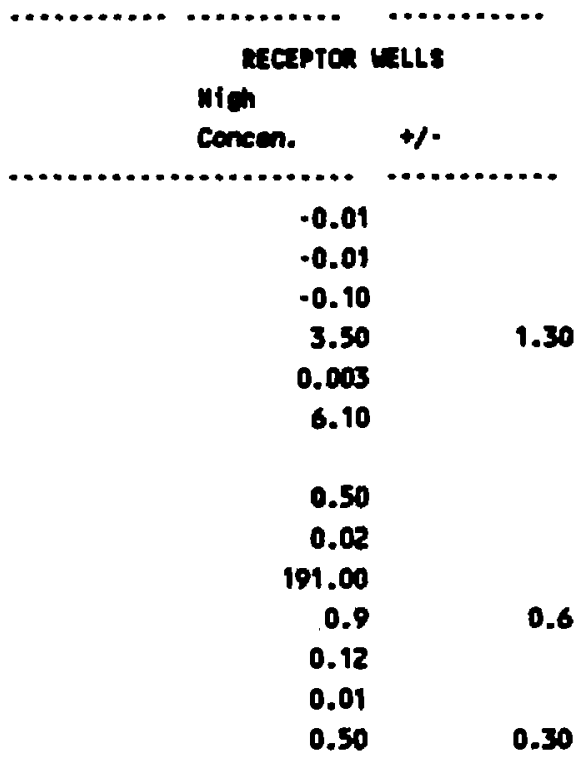

10 |Cremieal Units

111

$12|\cdots \cdots \cdot \ldots|$

13 las as

14 jed

15 |Cr VI

16 | $1 \mathrm{mb} 210$ pCI/l

17 100

18 inos

19 |po-210 pci/l

$20 \mid$ Ina-226+o peist

21 lse

22 1004

$23 \mid \mathrm{m} \cdot 230 \mathrm{pCl} / \mathrm{l}$

24 ju

20 |v

0.50

0.30

27 |Ra-22s pCI/l

29

29

30 Moceured coneentratione - Monitor whlls

31

321

33 IChemical Units

monitor valls

341

351

36 |as

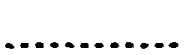

Mieh

Concen. $\quad+1-$

37 led

0.04

38 lCr vJ

$-0.001$

0.01

39 itb-210 peisll

$-1.50$

40 100

0.03

61 joos

36.00

42 |Po-210 pCi/l

43 |Ra-226ro pCI/l

4.70

46 lse wall

451004

$-0.005$

46 |Th-230 Ri/l

910.00

$-1.00$

$47 \mathrm{lu}$

il

0.069

48 |v

$1 /$

$-0.01$

49 |Ra-22s DCI/l

1.00

50 jRa-228 pei/l

3.70

$51 \ldots \ldots \ldots \ldots . . . \ldots \ldots$

52

53 mecured Concentration - seckground wetls

S4.

551

56 foremicel Units

57

581

se the

Deckground wells

Low

Concen. $+/ \cdot$ 
1

2 site thes: amisen, co, Alturiun

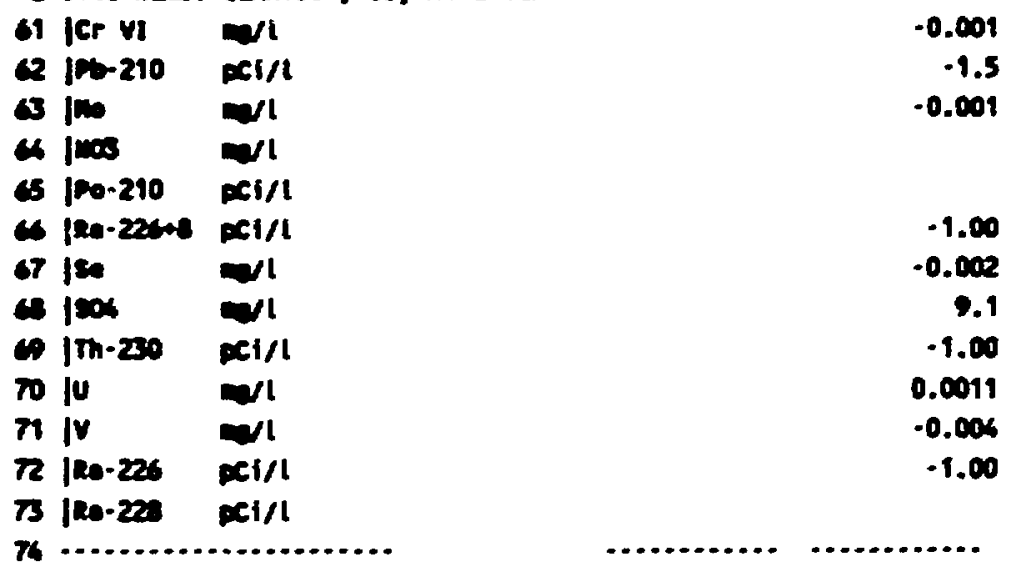

7

76 Colculated Uter Intekes - Receptore

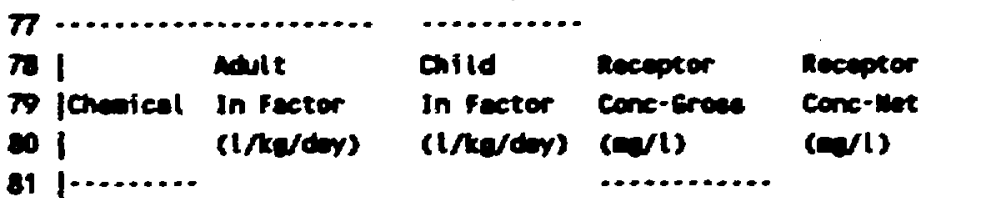

22 las

es jed

a ler vi

$85 \mid \omega b-210$

201 ino

8 j 1 inos

apo-210

0 |Ro-22648

90 lse

91 1504

92 1 $\mathbf{n}-230$

95 ju

96

95 |Ro.226

96 | $100-223$

97 ........................
0.03

0.03

0.03

0.03

0.03

0.03

0.03

0.03

0.05

0.05

0.05

0.05

0.03

0.03

0.03
0.10

0.10

0.10

0.10

0.10

0.25

0.10

0.10

0.10

0.10

0.10

0.10

0.10

0.10

0.10
0.0

0.0

0.0

3.5

0.0

0.1

0.5

0.0

191.0

0.9

0.1

0.0

0.5

0.0
0.000

0.000

0.000

3.500

0.003

6.100

0.500

0.020

181.900

0.900

0.119

0.010

0.500

0.000
Recupter Recepter Recepter iecepter adult-erew Child-erese nutt-mot child-wet

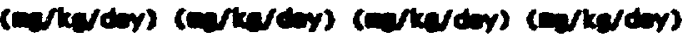

$\begin{array}{cccc}0.00 & 0.00 & 0.00 & 0.00 \\ 0.00 & 0.00 & 0.00 & 0.00 \\ 0.00 & 0.00 & 0.01 & 0.00 \\ 0.10 & 0.55 & 0.10 & 0.35 \\ 0.00 & 0.00 & 0.00 & 0.00 \\ 0.17 & 1.53 & 0.17 & 1.53 \\ 0.01 & 0.05 & 0.01 & 0.05 \\ 0.00 & 0.00 & 0.00 & 0.00 \\ 5.66 & 19.10 & 5.20 & 18.19 \\ 0.05 & 0.05 & 0.05 & 0.05 \\ 0.00 & 0.01 & 0.00 & 0.01 \\ 0.00 & 0.00 & 0.00 & 0.00 \\ 0.01 & 0.05 & 0.01 & 0.05 \\ 0.00 & 0.00 & 0.00 & 0.00\end{array}$

9

9 Calculated unter Intekes - Wonitor

\section{0}

101

102 themice 1031

$1041 \ldots . . . . .$.

105 ine

100 led

107 ler vj
Adult

In fector $(1 / \mathrm{kg} / \mathrm{dar})$

\section{Child \\ In Fector}

(1//kg/doy)

\section{monitor \\ cone-Gross}

$(m / 1)$

\section{monitor \\ conc-wet} $(\operatorname{mos} 1)$ monitor Monitor monitor monitor Mdult-Grose Child-Groses nult-met child-wet

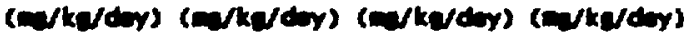

$\begin{array}{llll}0.03 & 0.10 & 0.0 & 0.060 \\ 0.03 & 0.10 & 0.0 & 0.000 \\ 0.03 & 0.10 & 0.0 & 0.010\end{array}$

0.00

0.00

0.00
0.00

0.00

0.00
0.00

0.00

0.00

0.00 


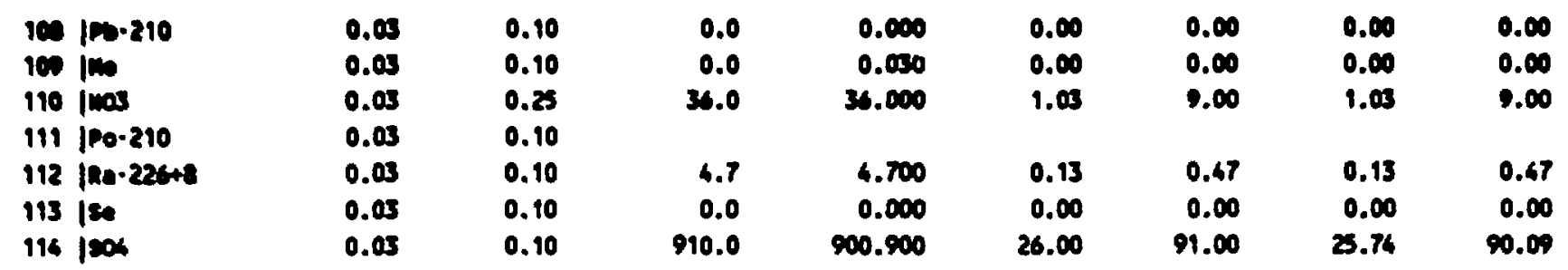

2 site Mems: amison, Co, Alluviu

\begin{tabular}{|c|c|c|c|c|c|c|c|c|}
\hline 115 |Th-230 & 0.03 & 0.10 & 0.0 & 0.000 & 0.00 & 0.00 & 0.00 & 0.00 \\
\hline $116 \mid 0$ & 0.03 & 0.10 & 0.1 & 0.068 & 0.00 & 0.01 & $0 . \infty 0$ & 0.08 \\
\hline $117 \mathrm{IV}$ & 0.03 & 0.10 & 0.0 & 0.000 & 0.00 & 0.00 & 0.00 & 0.00 \\
\hline 118 |Ro-226 & 0.03 & 0.10 & 1.0 & 1.000 & 0.03 & 0.10 & 0.03 & 0.10 \\
\hline 119 |Ra-220 & 0.03 & 0.10 & 3.7 & 3.700 & 0.11 & 0.37 & 0.11 & 0.37 \\
\hline
\end{tabular}

120

122 colculated Riske - subchronic

123 .............

1261 AIs

125 |cheaical Toxicity Receptor Receptor Receptor Receptor Monitor Nonitor Monitor Monitor 126 (ma/ke/doy) Mdult-Gross Child-Groes Adult-list 127 1...........

128 las

129 led

$1.40 E-03$

130 |cr VI

$131 \mid \omega b-210$

132 |1100

133 |1103

134 |Po-210

135 |Ra-226+8

136 ise

337 1004

138 |Th-230

139 iu

160 iv

$161 \mid 20-226$

142 |Re-228

143 ............

146

145 calculated Risks - Chronic

146 .............

1471 AIC

148 fChemical Toxicity Roceptor Receptor Receptor 1491

150

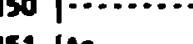$$
\text { (5) }
$$

152 jed

$1.200-03$

0.0

$2.506-02$

m

0.0

0.0

0.0

M

$m$

$1.10 E+01 \quad m_{m}^{m} \quad 0.1$

m

$3.20<-03$

m

153 JCr VI

154 | $106-210$

155 ino (no/kg/doy) Adult-Gross Child-Gross Mdult-Met

0.0
$m$
0.0
$m$
$m$
$m$
$m$
0.2
$m$
$m$
0.0
$m$
$m$

$m$
Child-Whet Mdult-Grose Child-Groses Mdult-wet Child-Wet 


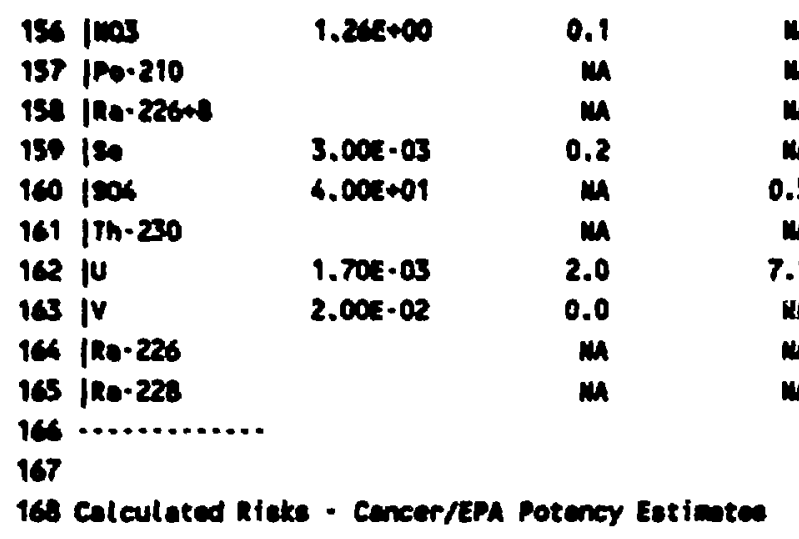

$\begin{array}{ccccc}0.1 & m & 0.0 & m & 0.1 \\ m & m & m & m & m \\ m & m & m & m & m \\ m & m & 0.0 & m & 0.0 \\ m & 0.5 & m & 2.3 & m \\ 0.0 & m & m & m & m \\ m & m & 1.2 & 4.1 & 1.1 \\ m & m & 0.0 & m & 0.0 \\ m & m & m & m & m\end{array}$

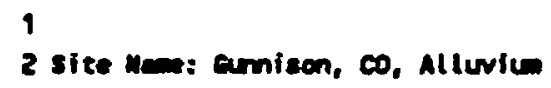

in

M

1.16E-0B

M

M

3.65E-04

$\begin{array}{ll}m & M \\ m & M \\ m & 1.14 E-0 \\ m & M\end{array}$

$\begin{array}{cc}1.71 E-02 & 1.71 E-02 \\ m & m \\ m & m \\ m & 0.00 E+\infty 00 \\ m & m\end{array}$




\begin{tabular}{|c|c|c|c|c|c|}
\hline $\begin{array}{l}204 \text { |he- } \\
203 \text { les }\end{array}$ & & $3.535 \cdot 05$ & $3.3 x x \cdot c s$ & $3.65 \cdot 05$ & $3.45 \cdot 05$ \\
\hline we twa & m & 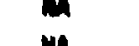 & in & 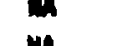 & $m$ \\
\hline 207 |Th-230 & 1.10.06 & $3.035 \cdot 0$ & $3.05 x-0 s$ & $0.001+00$ & $0.00+400$ \\
\hline ju-nat & $5.49 \cdot .05$ & $1.28: 04$ & $1.27 \cdot 04$ & 7.3e:-0s & $7.208 \cdot 05$ \\
\hline |v & $m$ & $\omega$ & $m$ & $m$ & $m$ \\
\hline |Re-226 & $2.675 \cdot 06$ & $3.532 \cdot 06$ & $3.53 x-06$ & 7.06e-06 & 7.0es. 06 \\
\hline 11 |Ro-228 & $2.7 m-04$ & $0.002+\infty 0$ & $0.00 t+\infty 0$ & $2.935-05$ & $2.935-05$ \\
\hline
\end{tabular}


1

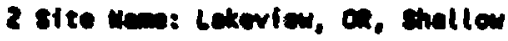

7 mesured cencentrations - Receptor Holls

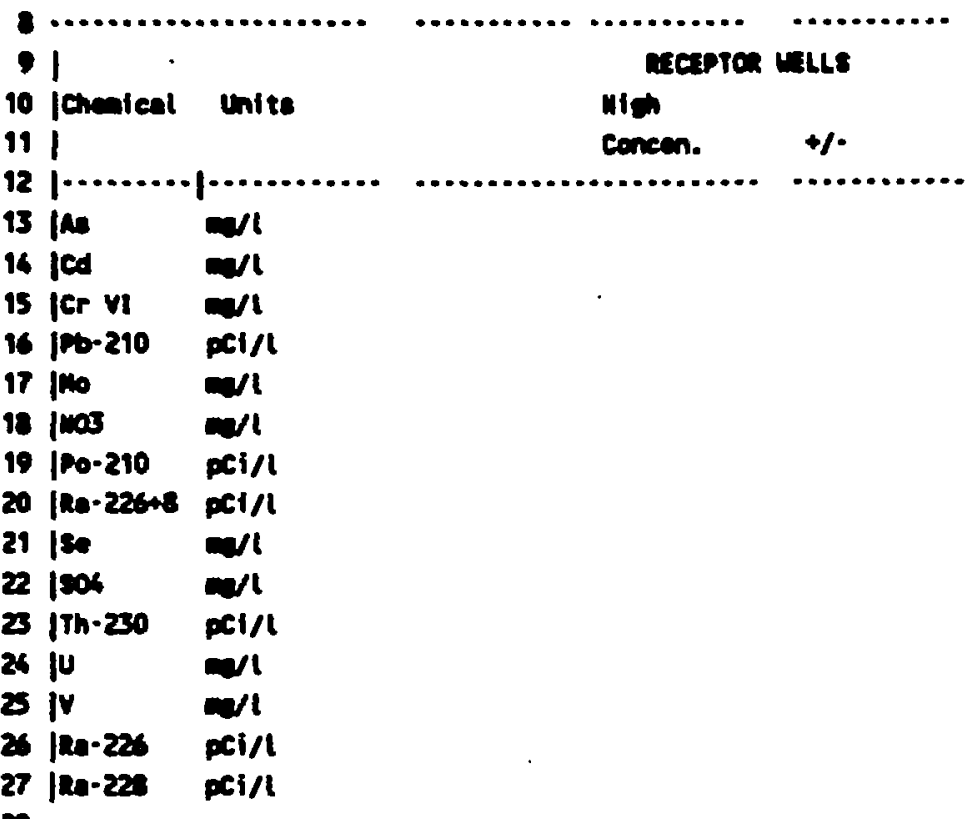

28 ...........................

29

30 masured concentration - Monitor uells

31

321

33 |chenicel units

3* 1

31

38 in

$1 \cdot$

m/1

37 icd

$38|\mathrm{Cr} v| \mathrm{m} / \mathrm{s}$

39 /ro-z10 pel/l

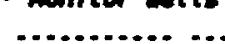

40 the nos

$41 \operatorname{lnos} \quad \mathrm{n} / 1$

$42 / 00-210 \mathrm{pci/l}$

43 |Re-226+8 pci/l

4 fise neve

$451504 \quad 0 / 1$

46 Im-230 pei/l

$47 \mathrm{j} \quad \mathrm{ev}$

4 | 1

49 jeo-226 pei/l

noniter wells

Mich

Concen. $\quad+/$

50 |Ro-22s pel/l

0.10

0.031

0.0

$-1.00$

0.18

14.00

9.10

2.9

$-0.005$

3150

1.60 .6

0.003

0.02

$\begin{array}{ll}0.5 & 0.2 \\ 2.6 & 0.9\end{array}$

21 ......................

1.80

52

53 mesured concentration - Eackground walle

S4

551

56 |Chenical Unite

eckeround wel Is

57 I

581

59 las

..........

n

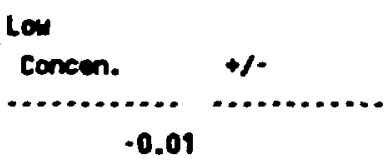


1

2 site nums Lekevien, on, shollew

$\$ 1$ ler vi $\mathrm{ell}$

2 Iro-210 pet/l

3 ino

a $\operatorname{lnos} 0 / 1$

\& po-210 pi/l

cs lino-zate peill

6 ise

4 joos and

6 ITh-200 pis

$\pi \mathrm{j}$

$\pi$ |v $\mathrm{all}$

72 |ro-2as pill

$\pi$ |Re-2es

$74 \ldots \ldots \ldots$

is

7 celculated wter Intakes - Receptors

$\pi$

$\pi$

7 |chemical

0 I

a) $1 \ldots \ldots \ldots$

2 |as

o jed

es Ier vi

s $\mid \omega-210$

co Ino

8 inos

a |Pa-210

(1ne-226+8

is ISe

9 |cos

$2 \mid \mathrm{m}-220$

s $\mid u$

\% IV

is |Re-226

es |Re-22s

$\boldsymbol{\gamma}$

s.

99 Colculeted water Intekes - Monitor

100 .........................

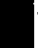

1

1

Adult

In Fector

(1/ke/dey)

$\begin{array}{ll}\text { Child } & \text { Receptor } \\ \text { In Fector } & \text { Conc-Groes } \\ \text { (I/ke/day) } & (\mathrm{m} / 1)\end{array}$

Receptor

Conc-liet

(a)/1)

.............

$0.03 \quad 0.20$

$0.03 \quad 0.20$

$0.03 \quad 0.20$

$0.03 \quad 0.20$

$0.03 \quad 0.20$

$0.03 \quad 0.35$

$0.03 \quad 0.20$

$0.03 \quad 0.20$

$0.03 \quad 0.20$

$0.03 \quad 0.20$

$0.03 \quad 0.20$

$0.03 \quad 0.20$

$0.03 \quad 0.20$

$0.05 \quad 0.20$

$0.03 \quad 0.20$

$\begin{array}{llll}\text { Adult } & \text { Child } & \text { Monitor } & \text { Monitor } \\ \text { In fector } & \text { In Factor conc-Groes } & \text { Cone-llet }\end{array}$

$(1 / \mathrm{kg} / \mathrm{day})$

(l/kg/dery)

(m) $/(1)$

(m) l)

Receptor Receptor Receptor Receptor Adult-Groas Child-eroes Adult-lwet Child-liet (m/ke/dry) ( $\mathrm{m} / \mathrm{kg} / \mathrm{dy})(\mathrm{m} / \mathrm{kg} / \mathrm{dry})(\mathrm{m} / \mathrm{kg} / \mathrm{day})$

$-0.010$

$-1.00$

$-0.010$

$-1.00$

$-0.50$

.1 .00

$-0.005$

3.00

.1 .00

.0 .001

$-0.05$

$-1.00$

$-1.00$

04 1..........

ios |As

0.03

..............

0.1

0.0

0.100

0.20

0.0

0.031

0.040

0.20

0.03

0.00

0.00

0.01

0.00

0.09

Monitor Monitor Monitor Monitor Adult-Groas Child-Growe ndult-met Child-met (ma/kg/day) (mo/kg/day) (m/kg/dwy) (nj/kg/day)

0.02

0.01

0.00

0.01 


\begin{tabular}{|c|c|c|c|c|c|c|c|c|}
\hline $105 \mid ⿱ ㇒ ⿻ 丷 木-210$ & 0.08 & 0.20 & 0.0 & 0.000 & 0.00 & 0.00 & 0.00 & 0.00 \\
\hline 109 in & 0.08 & 0.20 & 0.2 & $0.1 c 0$ & 0.01 & 0.06 & 0.01 & 0.04 \\
\hline 110 / & 0.08 & 0.35 & 16.0 & 14.000 & 0.60 & 4.00 & 0.60 & 4.90 \\
\hline 111 100-210 & 0.08 & 0.20 & 9.1 & 9.100 & 0.26 & 1.12 & 0.26 & 1.22 \\
\hline 112 |Ro-22and & 0.08 & 0.20 & 2.9 & 2.500 & 0.00 & 0.50 & 0.05 & 0.50 \\
\hline 113 /se & 0.08 & 0.20 & 0.0 & 0.000 & 0.00 & 0.00 & 0.00 & 0.00 \\
\hline 1141006 & 0.08 & 0.20 & 3150.0 & 3147.000 & 90.00 & $\mathbf{1 3 0 . 0 0}$ & 0.91 & 69.40 \\
\hline
\end{tabular}

1

2 site Hene: Lakevien, On, shallow

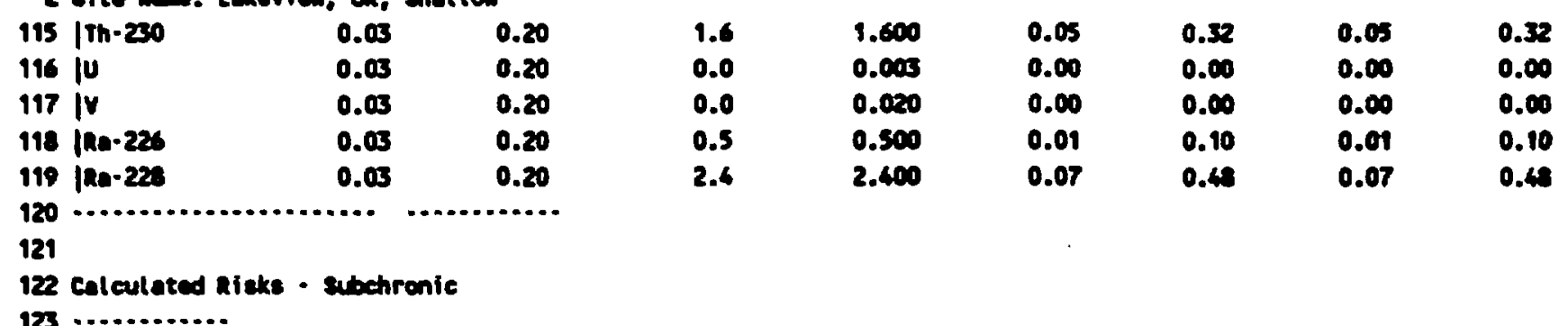

126 I Ats

125 |chemical Toxicity Receptor Receptor Roceptor

1261 (ma/ky/doy) Mdult-Groes child-Groses ndult-wet

Receptor monitor

Moniter

monitor

monitor 127 [...........

120 ine $\quad 1.40 \mathrm{e}-0 \mathrm{~B}$

129 led $1.20 \mathrm{ed}-03$

130 ler vi. 2.50E-02

131 |Pb-210

132 | 100

133 |11003

$1.10 E+01$

$136 \mid 100-210$

135 jRo-226+s

136 ise

137 inos

133 | $1 \mathrm{th}-230$

139 ju

160 iv

141 | $100-228$

142 |Ra.228

$163 \ldots \ldots \ldots . . . . .$.

Child-Wet Mdult-Groes child-Groes ndult-Mat

cuild-wat

146

145 Calculated Risks - Chronic

1467 .............

1471 aIC

148 jChemical

1491

$150 \mid \ldots . . . . .$.

151 las $\quad 1.40 E \cdot 03$

152 led. 2.900 .04

153 |Cr VI $5.00 E \cdot 03$

154 iro-210

155 ino

2.90e-03

$\begin{array}{ccc}2.0 & 16.3 & 2.0 \\ m & 5.2 & m \\ m & m & 0.0 \\ m & m & m \\ m & m & m \\ m & m & m \\ m & m & m \\ m & m & 0.0 \\ m & m & m \\ m & m & m \\ m & m & 0.1 \\ m & m & m\end{array}$

\begin{tabular}{|c|c|c|c|c|}
\hline $\begin{array}{l}\text { Receptor } \\
\text { child-Met }\end{array}$ & $\begin{array}{l}\text { Aoniter } \\
\text { Adut t-Eroes }\end{array}$ & $\begin{array}{l}\text { meniter } \\
\text { Child-erease }\end{array}$ & $\begin{array}{l}\text { monitor } \\
\text { sodule-Met }\end{array}$ & $\begin{array}{l}\text { monitor } \\
\text { Child-inet }\end{array}$ \\
\hline & 2.0 & 16.3 & 2.0 & \\
\hline & 3.1 & 21.6 & 3.1 & \\
\hline & 0.2 & $\boldsymbol{m}$ & 0.2 & \\
\hline & $m$ & $\mathbf{M}$ & $m$ & \\
\hline & 1.8 & 12.4 & 1.8 & \\
\hline
\end{tabular}




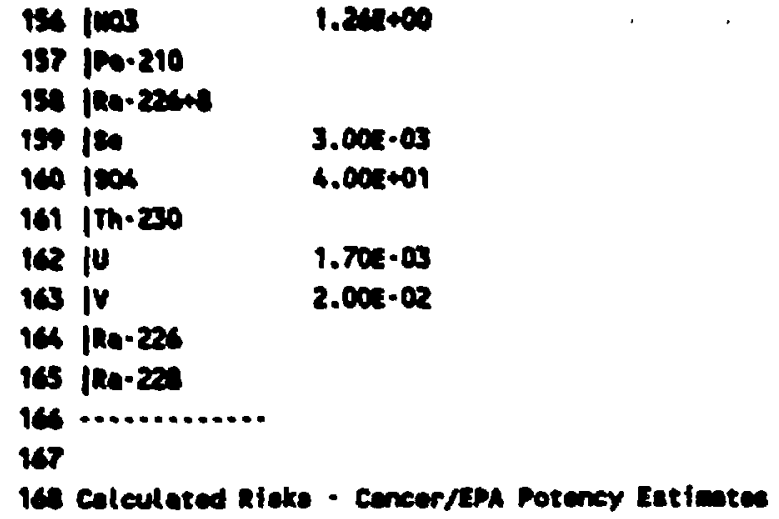

1

2 site mess Lekeview, on, shollow

$169 . . . . . . . . . .$.

170 Potency

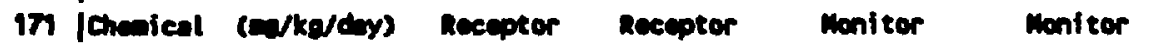

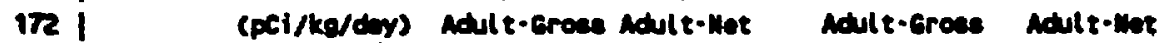

173

176 ins $1.505+01$

175 lcd $m$

176 |cr vI

17 |rb-210 1.40E-0

in ins in

17 jos in

109 |Po-210 3.6ez-06

141 | $100-226+8$

in lse

193 isor

1es Ith-200

18 ju-net

$193 \mathrm{IV}$

187 |Re-226

11 |Re-22s

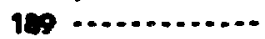

190

191 Calculated nisks - Cencer/lakp potencr Eetinatea

192 ..............

19s 1 Potency

196 (Chmical (m/ke/dey) Reeeptor Receptor Monitor Monitor

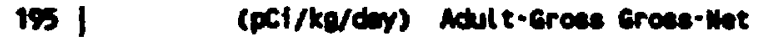
198 $1 \ldots \ldots \ldots$

197 las $1.50 t+0 t$

19 jed in

199 ICr vi m

200 |ro-210 1.14E-0s

201 ino in

$2021 \mathrm{mos}$

203 100-210 3.65E-04

\begin{tabular}{|c|c|}
\hline $4.291-02$ & $4.2 \%-02$ \\
\hline$m$ & $\mathbf{M}$ \\
\hline $\mathbf{M}$ & $M$ \\
\hline $0.00 \pi+00$ & $0.005+00$ \\
\hline$m$ & $m$ \\
\hline$m$ & $\boldsymbol{m}$ \\
\hline $9.5 \pi-05$ & $9.5 \pi-65$ \\
\hline $2.02-05$ & $2.025-65$ \\
\hline$m$ & $m$ \\
\hline$m$ & $m$ \\
\hline $3.524-06$ & $3.524-05$ \\
\hline $2.76 x-06$ & $2.7 c=-06$ \\
\hline$m$ & $\mathbf{M}$ \\
\hline $4.40 E-06$ & 4.40E-06 \\
\hline $1.58 z-05$ & $1.58 z-05$ \\
\hline
\end{tabular}

Adult-Grose Adult-lint

$\begin{array}{cc}4.292-02 & 4.292-02 \\ m & m \\ m & m \\ 0.005+00 & 0.001+00 \\ m & m \\ 9.49 E-05 & 9.49 E-05\end{array}$

$\begin{array}{rrrr}0.3 & m & 0.3 & m \\ m & m & m & m \\ m & m & m & m \\ m & m & 0.0 & m \\ 0.1 & 15.8 & m & 15.7 \\ 0.0 & m & m & m \\ m & m & 0.1 & 0.6 \\ m & m & m & m\end{array}$


and hooran

205160

2001006

207 ith-230

200 ju-not

200 is

210 |Re. 226

211 |Re-220

212 ............ $m$

$1.10+04$

S. $695 \cdot 05$

m

$2.67 \cdot 0$

$2 . \pi \mathrm{r} \cdot 0$
$2.284 \cdot 05 \quad 2.24 \cdot 05$

in

M

m

5.3\%-0 5.3\%-06

3.21E-0 3.21E-OS

Ma

3.535-00 3.53x-OS

$1.905 .05 \quad 1.905 .65$ 
1

2 site Hem: Lekeview, On, Dexp

7 meveired concentration - heeptor walls

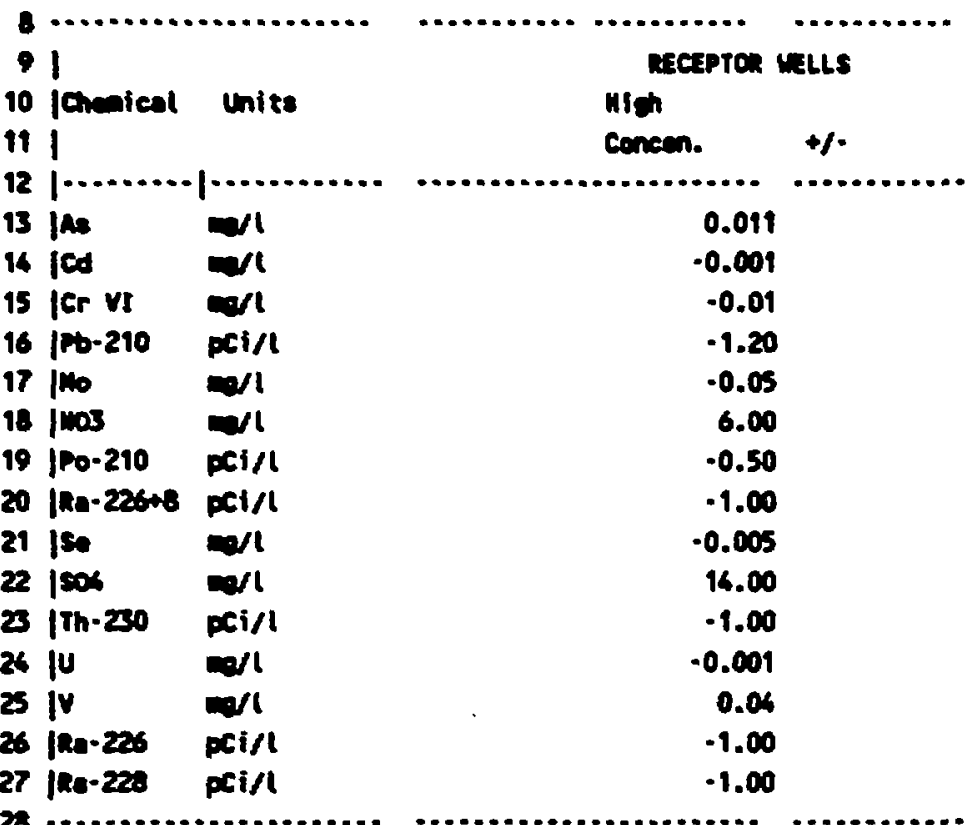

53 Meesured Concentrotions - Seckground Wells

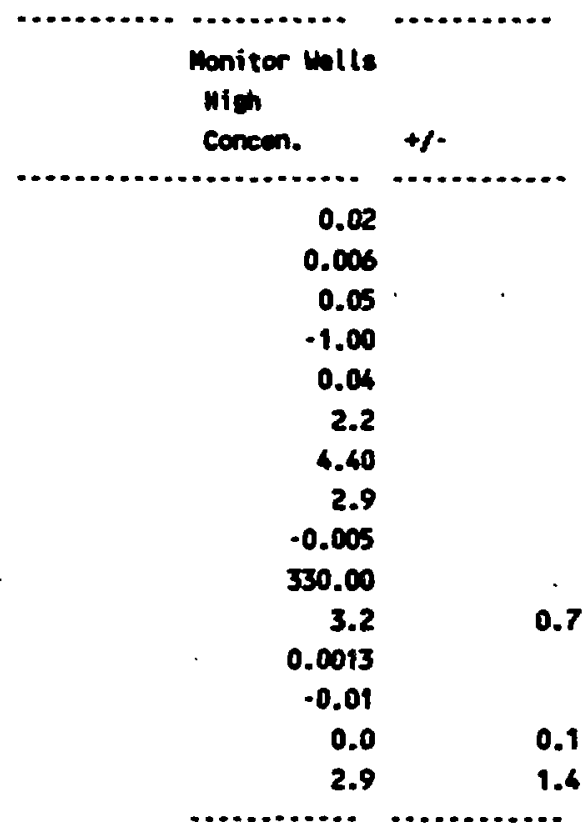

beckground Hells

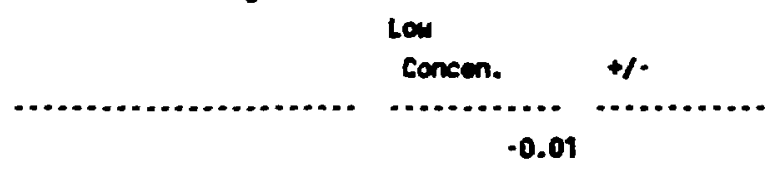


1

2 site nes: Letrevien, An, Desp

\begin{tabular}{|c|c|c|}
\hline 61 |Cr VI & $m$ & -0.01 \\
\hline $2 \mid r-210$ & pes/l & -1.00 \\
\hline 63 ino & $n$ & -0.01 \\
\hline $4 \mathrm{Imas}$ & إ/ & -1.00 \\
\hline 65 100-210 & $p 1 / 1$ & -0.50 \\
\hline 66 /120-226+8 & $\infty 1 / 1$ & -3.00 \\
\hline 67 lse & $m / 1$ & -0.055 \\
\hline c ins & 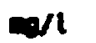 & 31.00 \\
\hline$\theta$ ith-230 & pill & -1.00 \\
\hline 70 & $m / 1$ & -0.001 \\
\hline $71 \mathrm{j}$ & $m / l$ & -0.01 \\
\hline the-226 & pill & -1.00 \\
\hline | & pelf & -1.00 \\
\hline
\end{tabular}

$74 \ldots \ldots \ldots \ldots \ldots$

is

76 Calculeted wter intake - Receptore

$\pi$

r.

Adult

Aild

Receptor

conc-Grees

$\infty 1$

81 1 $\ldots \ldots \ldots$

In fector

in factor

(and)

2 Ins

as led

Q ICr vi

as $1 \mathrm{~Pb}-210$

801 ino

87 inds

8. 100-210

ep |Re-226ns

of

91 loos

$92 / \mathrm{m} \cdot \mathbf{2} 0$

$\boldsymbol{\Phi} \mid \mathbf{U}$

94 IV

कs |Ro-226

96 |Ra-228

9

9

9 colculated Hater Intake - Monitor

100

101

0.03

0.03

0.03

0.03

0.03

0.03

0.03

0.03

0.03

0.03

0.03

0.03

0.03

0.03

0.03

\subsection{0}

0.10

0.10

0.10

0.10

0.25

0.10

0.10

0.10

0.10

0.10

0.10

0.10

0.10

0.10
0.01

0.01

$-1.00$

0.05

0.001

$-1.00$
Receptor Receptor Receptor Receptor Recepter Conc-wet ndult-eroes Child-Groal ndult-wet Child-wet

(novil) (co/kg/day) (ng/kg/day) ing/ke/day) (ma/kg/doy) -..............

0.0

0.0

0.0

0.0

0.0

6.0

0.0

0.0

0.0

16.0

0.0

0.0

0.0

0.0

0.0

0.019
0.000
0.000
0.000
0.000
6.000
0.000
0.000
0.000
-17.000
0.000
0.000
0.040
0.000
0.000

\subsection{0}

0.00

0.00

0.00

0.00

0.00

0.00

0.00

0.00

0.00

0.00

0.00

0.00

0.00

0.00

0.00

0.00

0.00

0.00

0.00

0.17

1.50

0.17

1.50

0.00

0.00

0.00

0.00

0.00

0.00

0.00

0.00

0.00

0.00

0.00

0.00

0.40

1.40

$-0.49$

$-1.75$

0.00

0.00

0.00

0.00

0.00

0.00

0.00

0.00

0.00

0.00

0.00

0.00

0.00

0.00

0.00

0.00

0.00

0.00

0.00

0.00
100

103

1061

105 ine

106 jed

107 |er vi adult Child Monitor

In fector

In fector conc-groses (1/kg/dar) (1/kg/day) (mo/l)

(noll)

Monitor
Cone. Met
$(m / 1)$

$\quad 0.020$
0.006
$\quad 0.050$

Monitor Monitor Monitor Monitor Mdult-Groes child-Grose sdult-wet child-wet (ma/kg/day) (mo/kg/doy) (mo/kg/doy) (mo/kg/dm)

$\begin{array}{llll}0.03 & 0.10 & 0.0 & 0.020 \\ 0.03 & 0.10 & 0.0 & 0.006 \\ 0.03 & 0.10 & 0.1 & 0.050\end{array}$

0.00

0.00

0.00

0.01

0.00

0.00

0.00

0.00

$\mathbf{0 . 0 0}$

0.00

0.01 


\begin{tabular}{|c|c|c|c|c|c|c|c|c|}
\hline $10100 \cdot 210$ & 0.08 & 0.10 & 0.0 & 0.000 & 0.00 & $0 . \infty 0$ & 0.00 & $0 . \infty 0$ \\
\hline 100 in & 0.08 & 0.10 & 0.0 & 0.060 & 0.00 & $0 . \infty 0$ & 0.00 & 0.00 \\
\hline 110 inos & 0.08 & 0.25 & 2.2 & 2.200 & 0.06 & 0.55 & 0.06 & 0.55 \\
\hline 111 ipo-210 & 0.03 & 0.10 & 4.6 & 4.400 & 0.13 & 0.46 & 0.13 & 0.46 \\
\hline 112 |Re-2264s & 0.03 & 0.10 & 2.9 & 2.900 & 0.08 & 0.29 & 0.00 & 0.29 \\
\hline 113 ise & 0.03 & 0.10 & 0.0 & 0.000 & 0.00 & 0.00 & 0.00 & 0.00 \\
\hline 1161804 & 0.03 & 0.10 & 330.0 & 299.000 & 9.63 & 33.00 & 8.56 & 29.90 \\
\hline
\end{tabular}

120

122 colculsted Rists - subchronic

$123 . . . . . . . . .$.

1261 Ats

125 fCheaical Taxicity

126

127 1..........

(Ea/ka/day) ndult-Grose Child-Groses atult-Wet

Receptor Monitor Monitor Monitor Monitor Child-Wet Mdult-Grose Child-Groses Mdult-Wet Child-Met

128 ins

129 icd

$1.40 E-03$

$1.206 \cdot 03$

2.50E-02

131 | $P$ - -210

132100

133 |nos

136 |Po-210

135 jea-226+8

136 jes

137 1004

138 ith-230

139 ju

$140 \mathrm{iv}$

361 |Ra-226

142 | $120-220$

163

144

165 calculated Rieks - Chronic

166 .............

167

160 tohenical tor

169 !

$1501 \ldots . . . .$.

151 1as

152 lad

153 icr VI

154 $1 \mathrm{~Pb}-210$

155 |1100

$1.10 e+01$

$3.20 E-03$

$1.006-02$

aic

Toxicity $(\mathrm{ag} / \mathrm{kg} / \mathrm{day})$

Receptor

Receptor

0.8
0.0
$m$

0.2

0.2

0.0

m

0.0

m

$m$

$m$

0.1

$m$

0.0

m

$m$

M

0.1

$m$

$\begin{array}{ccc}1.60 E-03 & 0.2 & 0.8 \\ 2.90 E-04 & 0.0 & M \\ 5.00 E-03 & 0.0 & M A \\ & M & M \\ 2.90 E-03 & 0.0 & 0.0\end{array}$

Receptor

Adult - Met
0.8
0.0
$m$
$m$
$m$
0.1
$m$
$m$
$m$
$m$
$m$
$m$
0.6
$m$
$m$
0.4
$m$
$m$
$m$
$m$
$m$
$m$
$m$
$m$
$m$
$m$
$m$
1.4
0.5
$m$
$m$
$m$
0.1
$m$
$m$
$m$
$m$
$m$
$m$
0.0
$m$
$m$
0.4

m

0.1

$m$

$m$

$m$

$m$

$m$

0.0

$m$

m

$m$

0.0

$m$

1.4
0.5
$m$
0.1
$m$
$m$
$m$
$m$
$m$
$m$
$m$
$m$
$m$

Receptor

moniter

Manitor

Monitor

monitor

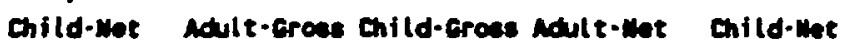

0.20 .8

0.0

0.0

0.0

$m$

m

0.0

0.0

0.6
0.6
0.3
0.6

0.4
1.4
2.1
m
$m$
1.4

(n) 


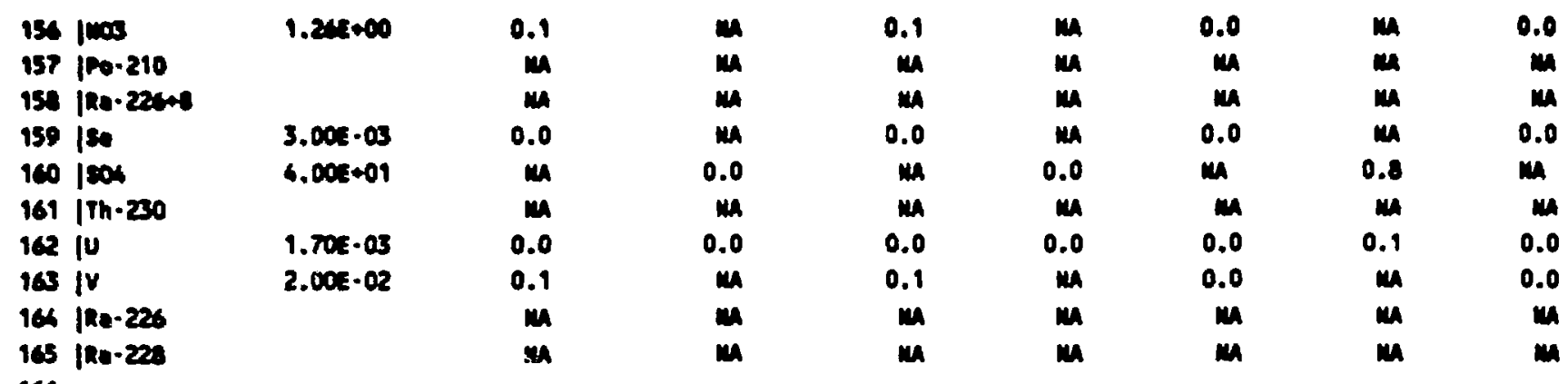

167

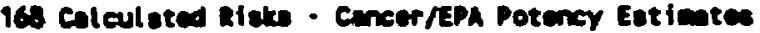

1

2 site mas: Lekerled, or, Deep

$169 . . . . . . . . .$.

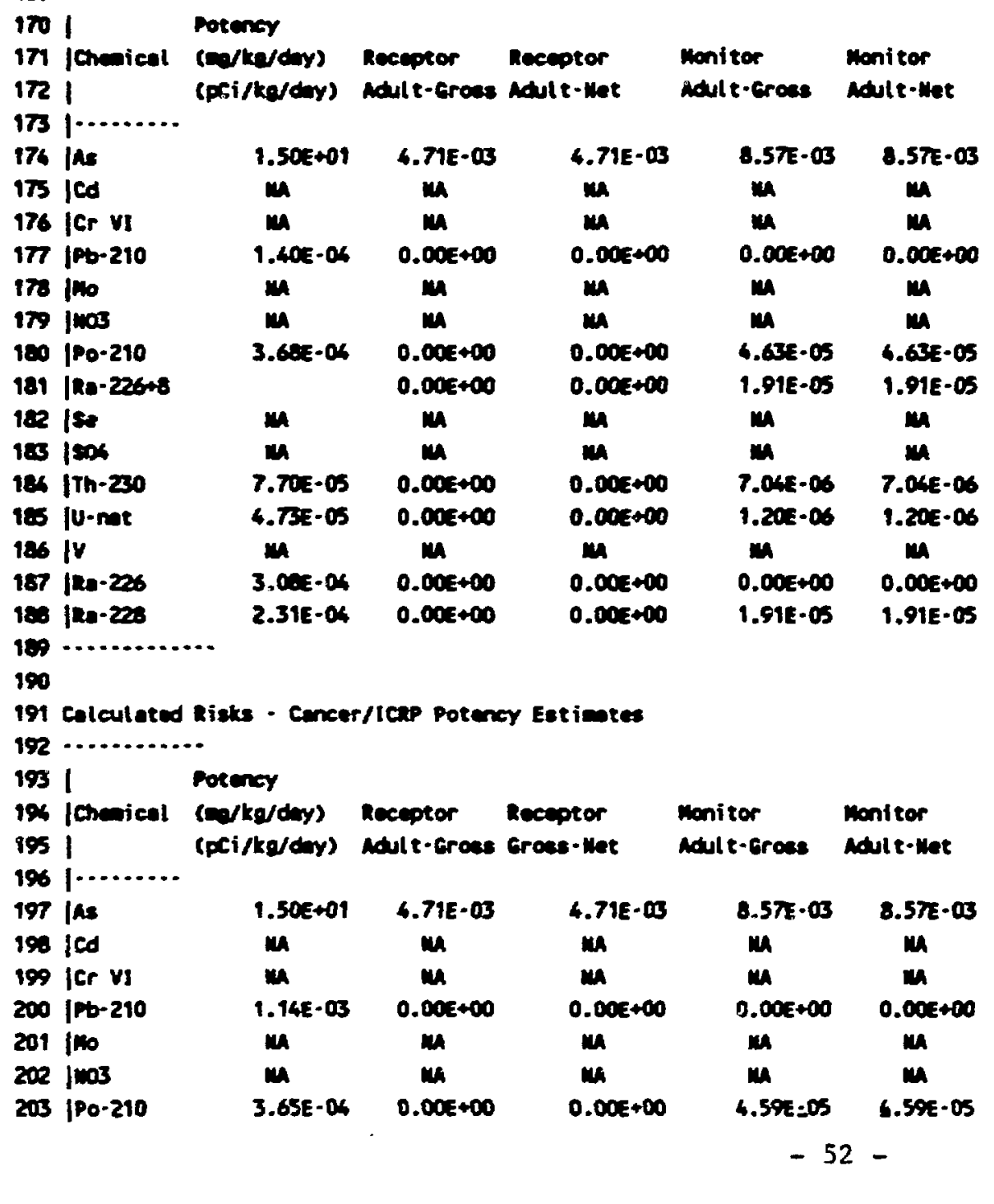




\begin{tabular}{|c|c|c|c|c|c|c|}
\hline 2 & |Re-2ache & & 0.001400 & $0.001+00$ & $2.312 \cdot 05$ & $2.305 \cdot \omega$ \\
\hline 205 & is & $m$ & $m$ & $m$ & $m$ & $m$ \\
\hline 205 & |est & $m$ & $\boldsymbol{m}$ & $m$ & $\mathbf{m}$ & $m$ \\
\hline 207 & $\mid T h \cdot 20$ & $1.10=-06$ & $0.002=00$ & $0.00 \leq+\infty 0$ & $1.0 \mathrm{cos} \cdot 0 \mathrm{~s}$ & $1.0=05$ \\
\hline 200 & W-nt & $5.695 \cdot$ os & $0.00 t * 00$ & $0.00 \div \div 00$ & $1.3 \%+05$ & $1.3 \%=06$ \\
\hline 209 & IV & $m$ & $m$ & $m$ & $m$ & $m$ \\
\hline 210 & |120.226 & $2.4 \pi \cdot 06$ & $0.002+00$ & $0.00 c+\infty 0$ & $0.00 E+\infty 0$ & $0.00 \leq+\infty 0$ \\
\hline 211 & jho-22s & $2.77 \mathrm{c} \cdot 0 \mathrm{~s}$ & $0.00 t+00$ & $0.00 t+\infty 0$ & $2.30 \mathrm{Cos}$ & $2.30 c \cdot 0 \mathrm{~s}$ \\
\hline
\end{tabular}

212 ........... 
1

2 site Mans: nomment volley, Az, Alluviun

7 mesured Concentration - Receptor Wells

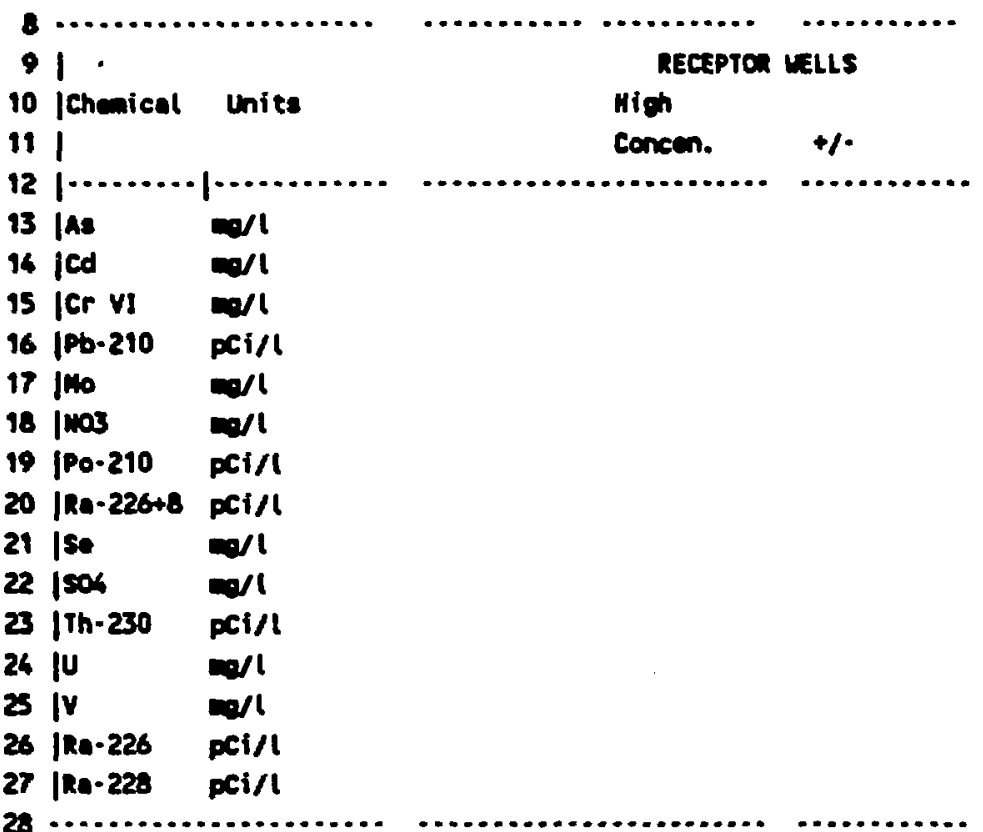

29

30 messured Concentrations - Monitor Halls

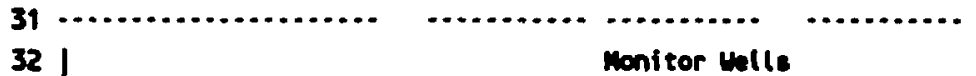

32 |

33 |Chemical Units

Monitor Halls

361

wich

35

36 jas

37 led $\mathrm{Codt}$

38 |Cr vi $\mathrm{crt}$

$39 \mathrm{~Pb}-210$ pCi/l

40 Ho

41 |1103

42 |Po-210 PCi/l

cancen. $+\%$

43 |Ra-226+8 pi/l

44 Ise

45 |so4 $\mathrm{moll}$

46 ITh-230 - pCi/l

$47 \mid \mathrm{U}$

$48 \mathrm{IV} \quad \mathrm{m} / \mathrm{l}$

49 |Ra-226 pi/l

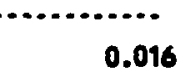

so |Ra-228 pCi/l

0.016

0.031

0.09

1.8

0.35

1600

1.90 .9

2.2

0.016

2960

$0.8 \quad 1.1$

0.0343

0.80

0.30 .2

1.90 .9

51 .........................

52

53 Mensured Concentration - Aeckground Uells

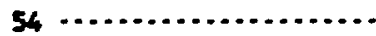

551

56 |chenical Unite

571

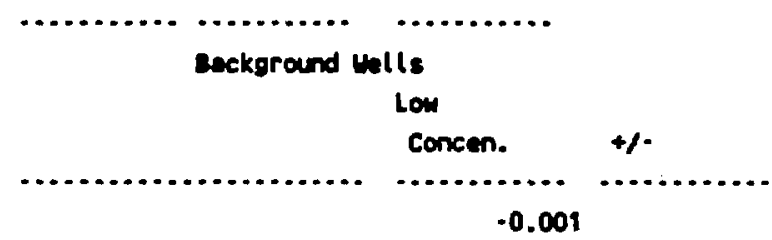

59 int

$m / 1$

$-0.001$ 


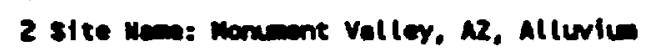

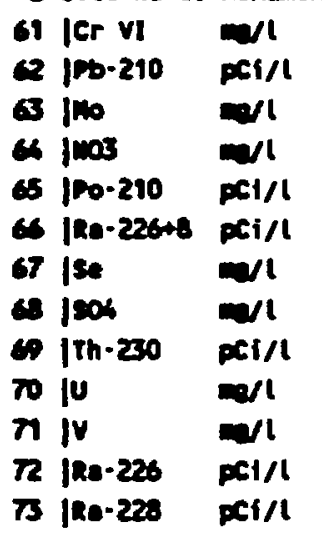

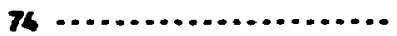

$\pi$

76 calculoted whter intekes - Receptors

7

78 $\pi$ 81

s1 1 ...........

2 jes

83 jed

a jer VI

es jat-210

2100

81003

ex pro-210

8 jRa-226+8

90 lse

91504

$92 \mathrm{ITh} \cdot 230$

9310

94 iv

95 |Ra-226

96 jea-228

97

90

99

10

$0.03 \quad 0.10$

$0.03 \quad 0.10$

$0.03 \quad 0.10$

$0.03 \quad 0.10$

$0.03 \quad 0.10$

$0.03 \quad 0.25$

$0.03 \quad 0.10$

$0.03 \quad 0.10$

$0.03 \quad 0.10$

$0.03 \quad 0.10$

$0.03 \quad 0.10$

$0.03 \quad 0.10$

$0.03 \quad 0.10$

$0.03 \quad 0.10$

$0.03 \quad 0.10$



9 calculoted thter Intakes - Monitor noult

In fector $(1 / \mathrm{kg} / \mathrm{doy})$

\section{child}

In fector

(1/kg/doy)

\section{Receptor}

cone-crose

(no/)

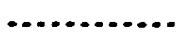

Receptor

cone- mot

(moti)

\begin{tabular}{rr}
-0.01 & \\
0.0 & \\
0.0 & \\
.1 & \\
0.0 & \\
0.0 & 0.5 \\
-0.005 & \\
55.00 & \\
0.00 & 0.6 \\
0.0025 & \\
-0.01 & \\
0.0 & 0.2 \\
0.0 & 0.7 \\
\hline .0 &
\end{tabular}

$-0.01$

1

0.5

.6

0.2

.7

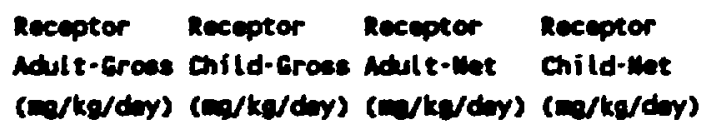

Receptor Receptor Receptor Receptor Mdult-Groas child-Groes Mdult-Met Child-wet (m/kg/dor) (ma/kg/doy) (m/ke/dry) (mo/kg/doy)

\begin{tabular}{|c|c|c|c|c|c|c|c|c|}
\hline $\begin{array}{ll}01 & \text { I } \\
02 & \text { IChenical } \\
03 & \text { I }\end{array}$ & $\begin{array}{l}\text { Adult } \\
\text { in Factor } \\
\text { (1/ka/doy) }\end{array}$ & $\begin{array}{l}\text { Child } \\
\text { In Fector } \\
\text { (1/kg/dey) }\end{array}$ & $\begin{array}{l}\text { Monitor } \\
\text { Conc-Grows } \\
(\mathbf{m} / 1)\end{array}$ & $\begin{array}{l}\text { monitor } \\
\text { conc-Net } \\
(\mathrm{me} / \mathrm{l})\end{array}$ & $\begin{array}{l}\text { Monitor } \\
\text { Adult -Gross } \\
\text { (on/kg/doy) }\end{array}$ & $\begin{array}{l}\text { Monitor } \\
\text { Child-Gross } \\
\text { (mo/kg/doy) }\end{array}$ & $\begin{array}{l}\text { Monitor } \\
\text { Nodult-wet } \\
(\mathbf{m o} / \mathrm{kg} / \mathrm{doy})\end{array}$ & $\begin{array}{l}\text { Monitor } \\
\text { Child-Met } \\
\text { (ma/kg/doy) }\end{array}$ \\
\hline ins & 0.03 & 0.10 & 0.0 & 0.016 & 0.00 & 0.00 & 0.00 & 0.00 \\
\hline 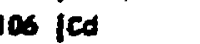 & 0.03 & 0.10 & 0.0 & 0.031 & 0.00 & 0.00 & 0.00 & 0.00 \\
\hline $\mathbf{v 1}$ & 0.03 & 0.10 & 0.1 & 0.090 & 0.00 & 0.01 & 0.00 & 0.01 \\
\hline
\end{tabular}




\begin{tabular}{|c|c|c|c|c|c|c|c|c|}
\hline $10 \mid 10-210$ & $0 . \boldsymbol{B}$ & 0.10 & 1.8 & 1.000 & 0.05 & 0.18 & 0.05 & 0.10 \\
\hline 10 ins & $0 . \boldsymbol{B}$ & 0.10 & 0.4 & 0.350 & 0.01 & 0.06 & 0.01 & 0.06 \\
\hline $110 \ln 03$ & 0.08 & 0.25 & 1600.0 & 1000.000 & 45.71 & 400.00 & 49.71 & 600.00 \\
\hline $111 / 00-210$ & 0.03 & 0.10 & 1.9 & 1.900 & 0.05 & 0.19 & 0.65 & 0.19 \\
\hline 112 ins.226n & 0.03 & 0.10 & 2.2 & 2.200 & 0.06 & 0.22 & 0.05 & 0.22 \\
\hline 113 ise & 0.03 & 0.10 & 0.0 & 0.016 & 0.00 & 0.00 & 0.00 & 0.00 \\
\hline 196 isos & 0.03 & 0.10 & 2960.0 & 2004.200 & 4.57 & 296.00 & 22.97 & 290.42 \\
\hline
\end{tabular}

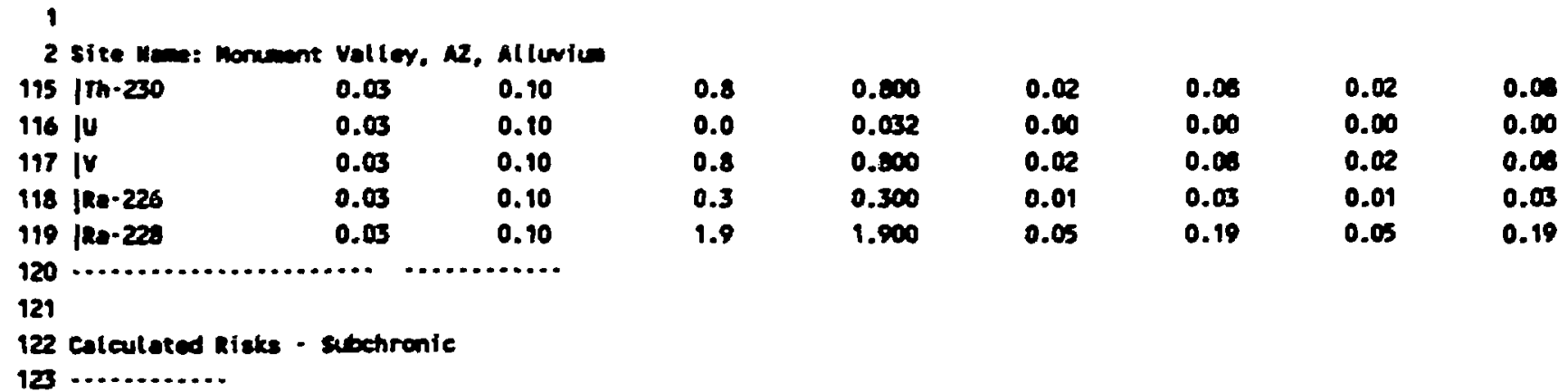

$\begin{array}{rrr}0.3 & 1.1 & 0.3 \\ m & 2.6 & m \\ m & m & 0.1 \\ m & m & m \\ m & m & m \\ m & 36.6 & m \\ 0.1 & m & m \\ m & m & m \\ m & m & 0.1 \\ m & m & m \\ m & m & m \\ m & m .3 & 2.3 \\ m & m & m\end{array}$




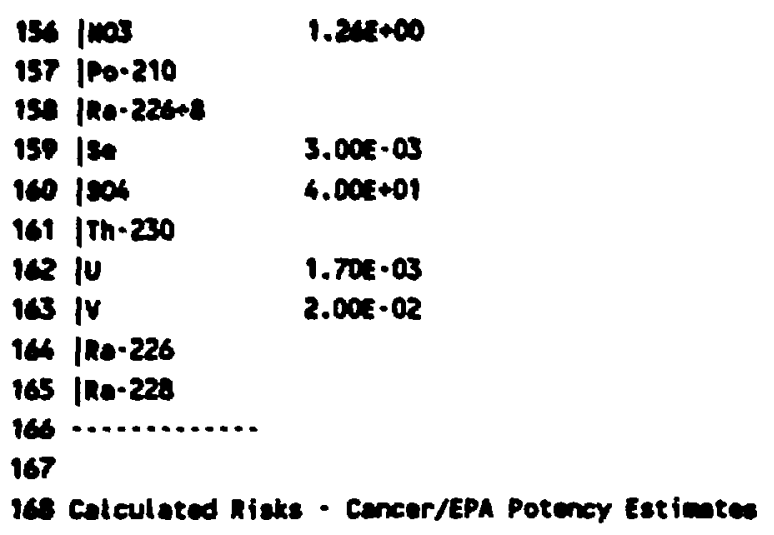

3.3 in

$m$

$m$

M

7.6

in

2.0

m

$m$

$m$
3.3
นท

in

$m$

M

7.3

m

1.9

$m$

$m$

$m$
1

2 site Mwa: Monement Volloy, AZ, Alluviu

169 .............

170

Poteney

171 |chereat

172

173 |........

176 ithe

175 fed

176 JCr VI

177 |Pb-210

178 / 10

179 inos

180 |Po-210

181 Ine-226+8

182 ISe

183 1506

184 ITh-20

105 fU-nat

186 IV

187 |Re-226

188 |na-228

189 ..............

190

191 Calculated Risks - Concer/ICRP Potency Est imates

192 .............

1931 Potency

194 |Chemical (m/kg/day) Receptor Receptor
i9s

196

197 jas

190 jCo

$1.50 E+01$

199 JCr VI

$m$

Ma

1.14E-03

Ma

M

3.65E-0h
20110

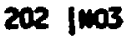

205 Po-210
Receptor keceptor Monitor mitor

adult-Gross idult-Wet

6.86E-03 6.86E-03

M M

$\mathrm{M} M$

$7.20 E-06 \quad 7.20 E-06$

$\mathrm{M} \mathrm{M}$

$M$

2.00E-05 2.00E-05

$1.521-05 \quad 1.521-05$

M M

M M

1.76E-06 1.76E-06

3.16E-05 2.93E-05

M M

2.64E-06 Z.64E-06

1.25E-05 1.25E-05

\begin{tabular}{|c|c|}
\hline $\begin{array}{l}\text { Menitor } \\
\text { Adult-Gross }\end{array}$ & $\begin{array}{l}\text { monitor } \\
\text { Notult - Net }\end{array}$ \\
\hline $6.86 E-03$ & $6.86 E-03$ \\
\hline$M$ & $\mathbf{M}$ \\
\hline$m$ & $\mathbf{M}$ \\
\hline $5.86 E-05$ & 5.86E-05 \\
\hline$m$ & $M$ \\
\hline$m$ & $m$ \\
\hline $1.90 E-05$ & $1.908-05$ \\
\hline
\end{tabular}


204 |Re-22in

20515

204 1004

$207 \mid \mathrm{Th}-230$

20 lu-nat

209 1V

210 |Re.226

211 [ke-228

$212 \ldots \ldots \ldots \ldots$
M

$m$

$1.182 \cdot 06$

S.496-05

m

$2.4 \pi \cdot 04$

2.TrE.04 1.7.6s 1.7a.to

M

M

M m

2.70E.06 $2.70 E .06$

3.67E-05 3.40E-05

M

MA

$2.125 .06 \quad 2.12 E \cdot 06$

$1.50 E-05 \quad 1.50 E-05$ 
1

2 st te Mese: Momenent Valley, N2, Shinarup

7 mescured Concentration - Receptor Welle

91

10 Jonmieal units

11 I

12

13 in

14 lad mod

15 for $v i \quad m$

16 FPb-210 pci/l

17 110

18 1003

19 |Po-210 pCi/l

20 |Ro-226+8 pci/l

21 Ise

22 1504

23 |Th-230 pCi/l

$2610 \quad \log / 1$

25 IV

26 |Re.226 PCi/l

27 |Re-228 pCi/l

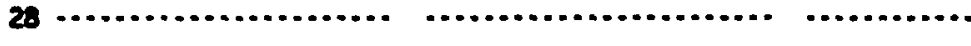

29

30 messured Conemtrations - Monitor wells

31

321

33 |cheaical Units

Monitor wells

341

351

36 ias

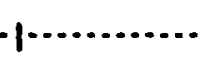

Nigh

37 lad

$m / 1$

concen. $\quad+\cdot$

38 |Cr VI

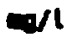

0.005

Hich

Concen. $\quad+1$.

39 |Pb-210 PCi/l

40 ino

61 |1003

$42 \mid$ Po-210 pCi/l

43 ira-226+8 pCi/l

44 lse

45 Isor mat!

46 |th-230 DCi/l

$47 \mathrm{fu} \quad \mathrm{D} / \mathrm{l}$

$48 \mathrm{jl} \quad \mathrm{mol}$

49 jRa-226 pci/l

50 |Ra-228 PCi/l

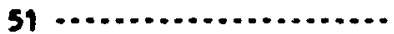

52

53 Heasured Concentratione - Eackground talls

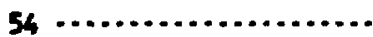

551

56 fChenical Units

571

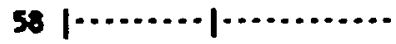

59 the

seckeround thells

0.07

2.8

0.25

40.00

0.3

1.80

$-0.005$

255

1.1

0.6

0.0315

0.7

1.60

0.20

0.5


1

2 site wes: Moment Valley, Ma, shinarup

\begin{tabular}{|c|c|c|c|c|}
\hline & |cr $v \mid$ & $m / l$ & -0.01 & \\
\hline & |rb-210 & $\mathrm{pei} / \mathrm{l}$ & 0.1 & 1.30 \\
\hline 6 & ino & $\mathbf{m}$ & -0.01 & \\
\hline 4 & 1008 & $\mathbf{m}$ & -1 & \\
\hline 65 & $100-210$ & pei/l & 0 & 0.6 \\
\hline 66 & |Ro-226+8 & poist & 0.1 & \\
\hline 67 & jes & $m / 1$ & -0.005 & \\
\hline 6 & 1004 & $\mathbf{m} / 1$ & 53.1 & \\
\hline 69 & | $7 h-230$ & pcill & 0.0 & 0.2 \\
\hline 70 & ju & $m$ & -0.0003 & \\
\hline$n$ & jv & $m / 1$ & -0.01 & \\
\hline 72 & |Ro-2226 & pcill & 0.1 & 0.20 \\
\hline 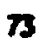 & |1Ro-220 & $p c 1 / 1$ & 0.00 & 0.90 \\
\hline
\end{tabular}

75

76 colculoted mter Inteke - Receptore

$\pi$........................ ............

71 Mdult Child Receptor Receptor Receptor Receptor Receptor Receptor

79 lanemical In fector in fector Cone-Groes Cone-Net Adult-Groes child-Grose Adult-Het Child-Net

$\infty$

(l/kg/doy) (1/ko/doy) (m/l) (m/l)

(mo/kg/day) (mo/kg/dry) (mo/kg/doy) (m/ $/ \mathrm{kg} / \mathrm{dry})$

81 1..........
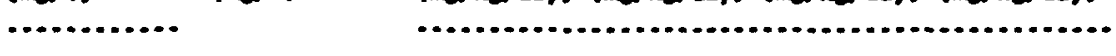

82 1Ne

0.03

0.10

3 led

0.03

0.10

at ICr vI

0.03

0.10

es |pb-210

0.03

0.10

86 |no

0.03

0.10

87 |003

0.03

0.23

es |po-210

0.03

0.10

8 |Ra-226+o

0.03

0.10

90 |se

0.03

0.10

91 1004

0.03

0.10

92 ITh-230

0.03

0.10

os ju

0.03

0.10

Q6 IV

0.03

0.10

95 |Ra-226

0.03

0.10

96 |Ro-223

0.03

0.10

97

9

9o Calculated Hater Intakes - Monitor

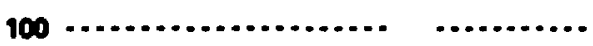

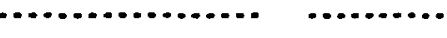

101 I Mdult Child Monitor Monitor Monitor Monitor Monitor Monitor

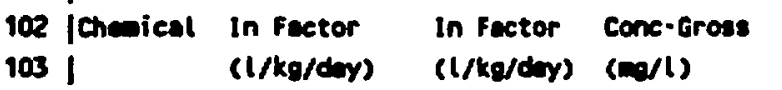

$1041 \ldots \ldots . . . .$.

$(1 / \mathrm{kg} / \mathrm{dmy}) \quad(1 / \mathrm{kg} / \mathrm{doy}) \quad(\mathrm{moll})$

Conc-Wet Adult-Grose Child-Groes ndult-Met Child-Net

(mo/l) (mo/kg/day) (mo/kg/dry) (m/kg/doy) (mo/kg/doy)

10S las

0.03

1. 10

0.0

0.005

106 led

0.03

0.10

0.0

0.004

...............

0.00

0.00

0.00

107 |Cr v1

0.03

0.10

0.1

0.070

0.00

0.00

0.00

0.00

0.00

0.01

0.00

0.01 


\begin{tabular}{|c|c|c|c|c|c|c|c|c|}
\hline $10 \mid \omega \cdot 210$ & 0.63 & 0.10 & 2.8 & 2.700 & 0.0 & 0.21 & 0.0 & 0.27 \\
\hline 100 ine & 0.08 & 0.10 & 0.3 & 0.230 & 0.01 & 0.03 & 0.01 & 0.03 \\
\hline 110 inos & 0.08 & 0.25 & 40.0 & 40.000 & 1.14 & 10.00 & 1.16 & 10.00 \\
\hline 111 & 0.03 & 0.10 & 0.3 & 0.300 & 0.01 & 0.03 & 0.01 & 0.03 \\
\hline 113 ist & 0.03 & 0.10 & 0.0 & 0.000 & 0.00 & 0.00 & 0.00 & 0.00 \\
\hline 114 Isos & 0.03 & 0.10 & 255.0 & 201.903 & 7.29 & 25.50 & 5.77 & 20.19 \\
\hline
\end{tabular}

2 site Wea: Monent Valley, M2, shinarue

\begin{tabular}{|c|c|c|c|c|c|c|c|}
\hline 115 |th-230 & 0.03 & 0.10 & 1.1 & 1.100 & 0.05 & 0.11 & 0.03 \\
\hline 116 |U & 0.03 & 0.10 & 0.0 & 0.032 & 0.00 & 0.00 & 0.00 \\
\hline 117 | & 0.03 & 0.10 & 0.7 & 0.700 & 0.02 & 0.07 & 0.02 \\
\hline 118 |Re-226 & 0.03 & 0.10 & 1.6 & 1.500 & 0.05 & 0.16 & 0.06 \\
\hline
\end{tabular}

12

122 Colculated Risks - Subchronic

123

1261 Als

125 /Chemical Toxicity Receptor Receptor Receptor 126

127. $1 \ldots \ldots \ldots$

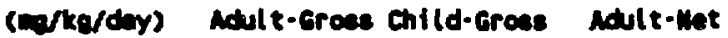

Receptor Monitor Monitor Monitor Monitor Child-met Adult-Groes Child-erose ndult-Wat child-Wet

1. SOE-0S

1.20E-03

$2.50 E-02$

130 Ier v

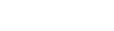

$1321 \mathrm{mo}$

$133 \mathrm{fmas}$

$1.10 E+01$

134 |Po-210

135 |Re-226re

136 fise

$3.20=-03$

38 |Th-230

139 ju

$160 \mathrm{IV}$

141 1Re.226

162 12.-228

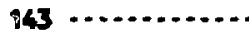

144

145 Calculated Riste - Chronic

146 ..............

167

AIC

148 |Chemical Texicity Receptor Receptor Receptor 1491 (wa/kg/doy) Adult-Gross Child-Gross Ndult-Wut

$\begin{array}{ccc}0.1 & 0.4 & 0.1 \\ m & 0.3 & m \\ m & m & 0.1 \\ m & m & m \\ m & m & m \\ m & 0.9 & m \\ m & m & m \\ m & m & m \\ 2.0 & m & 0.0 \\ m & m & m \\ m & m & m \\ m & m & 2.0 \\ m & m & m\end{array}$

Receptor Monitor Monitor Monitor Monitor
Child-Met Mdult-Gross Child-Gross Mdult-Met Child-Met
2.90E-04

5.00E-0s

$2.905-03$
0.1

0.4

0.4

1.4

0.4

M

2.5
Mn

M

8.6
0.1

0.4

0.6

แ

2.5
0.4

0.3

in

M

II

0.8

M

$\boldsymbol{m}$

w

$\mu$

7.0

M

$M$ 


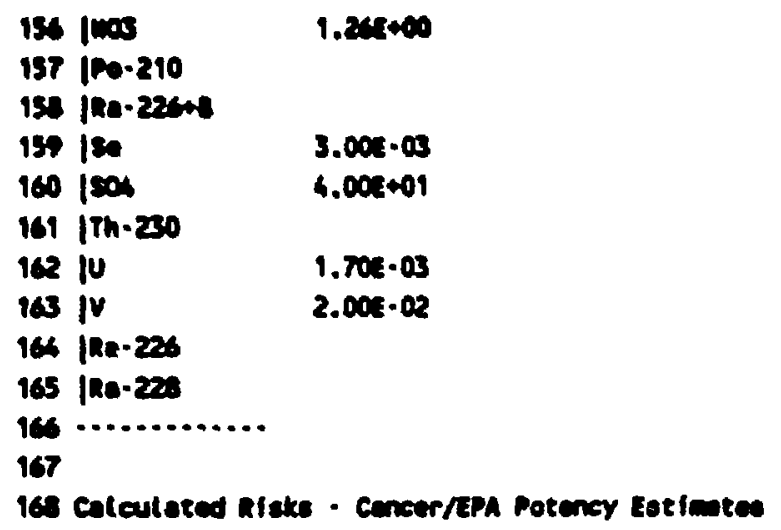

$\begin{array}{ccc}0.0 & m & 0.0 \\ m & m & m \\ m & m & m \\ m & m & 0.0 \\ 0.5 & 0.6 & m \\ 1.0 & m & m \\ m & m & 0.5 \\ m & m & 1.0\end{array}$

1

2 stee men: Monume Valley, AZ, shinarup

$169 . . . . . . . . . .$.

170 | Potency

171 |Chepical (nj/kg/day) neceptor neceptor

172

(pci/kg/dy) ndult-Groes ndult-net

Monitor monitor

Adult-Gross notult-Wot

$173 \mid \cdots \ldots . . .$.

174 ine

$1.505 * 01$

175 fCd

M

176 ICr $v$

M

$17 \mathbf{1} \mid \boldsymbol{b}-210$

$1.40 E-04$

178 ino

$\mathrm{m}$

179 linos

m

180 |ro-210

$3.602-06$

181 117n-226+8

182 the

M

103 1096

in

148 ith-2so

7.70e-0s

105 ju-nat

4.75e-0s

186 |V

แ

187 |no-2as

3.005-04

2.31E-04

$2.14 E-03 \quad 2.14 E-03$

$M$

$M$

$1.128-05 \quad 1.002-05$

m m

M M

3.15E-06 3.15E-06

1.56E-0S 1.45E-05

m M

M M

2.4x-06 2.475-06

2.90e-0s 2.90e-0s

M

M

1.41E-0s 1.32t-0s

$1.32 x-06 \quad 1.32 x-06$

169 ..............

190

191 Colculated Risks - Concer/ICRP Potency Eatinates

192 .............

193 | Potency

194 /Chmical (ma/kg/dey) Receptor Receptor Monitor Monitor

1951 (pci/kg/day) Adult-Grose Grose-Het

ndult-Groses adult-Wat

$196 \mid \ldots \ldots . . . .$.

197 ine $1.506 \cdot 01$

198 led

$199 \mathrm{JCr} \mathrm{VI}$

200 |Fb-210 $1.145-03$

201 100 in

$202 \operatorname{lng}$

in

203 |Po-210

3.65E-06

$\begin{array}{cc}2.14 E-03 & 2.14 E-03 \\ m & m \\ m & m \\ 9.12 E-05 & 8.79 E-05 \\ m & m \\ m & m \\ 3.13 E-06 & 3.13 E-06\end{array}$




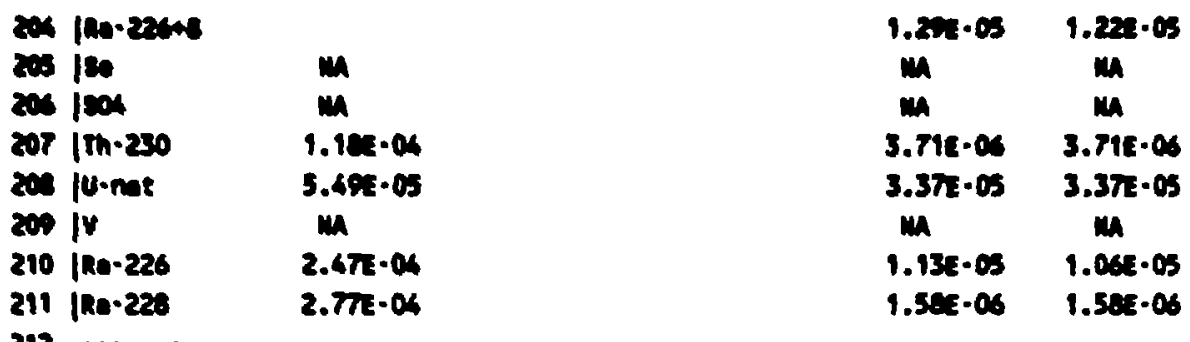


1

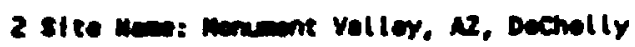

7 meaured concentration - Recepter walls

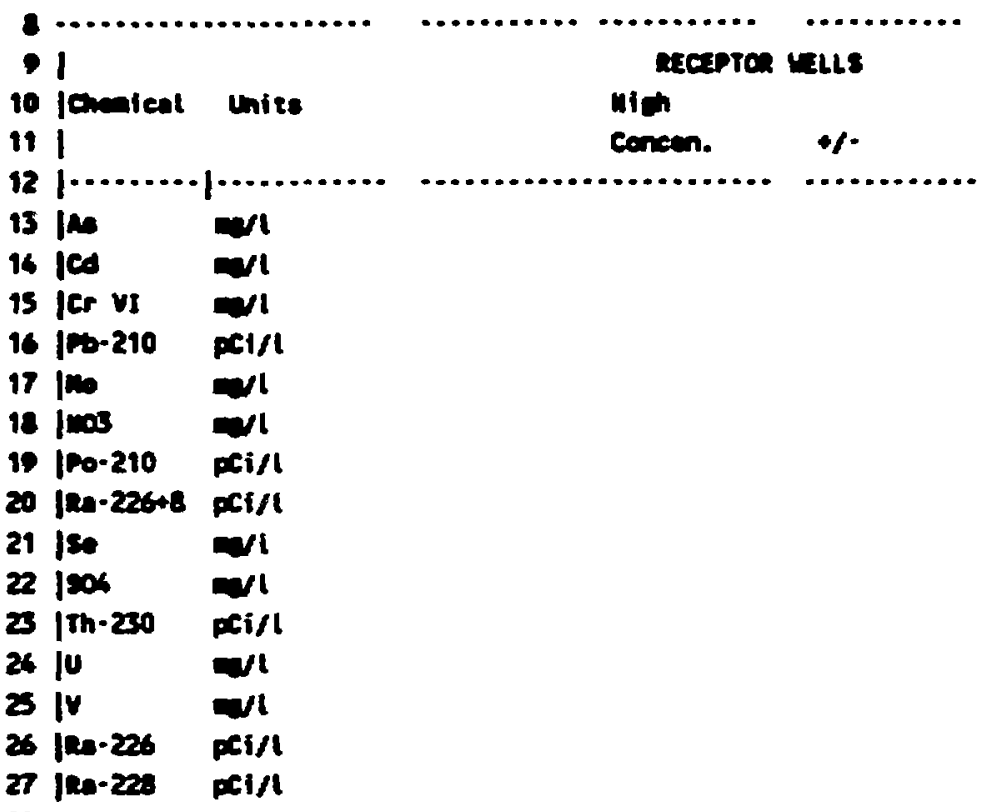

29

30 mecured concentration - monitor wolls

31 ........................

321

33 /Chemical Units

monitor ulle

34 I

351

36 ino

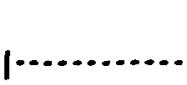

Mint

37 led

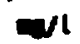

30 ler vi

$\mathbf{m}$

aris

39 jer-210 peis

401000

61 inos aris

42 |po-210 pel/l

43 |Re-22s+8 pis/l

is jes art

451504

46 ith-230 pei/l

47 ju $\quad$ a

45 iv a/l

49 [la-226 pi/l

concen. +1

50 |20-220 $\mathrm{xill}$

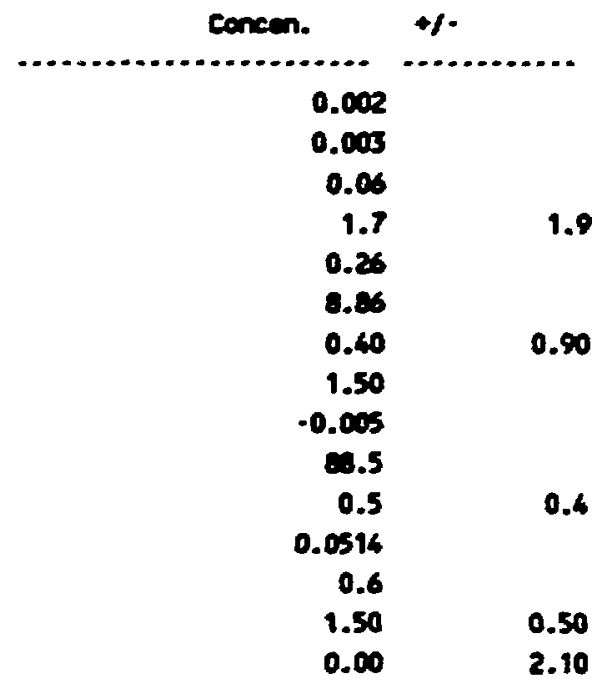

s1 $\ldots \ldots \ldots \ldots \ldots \ldots \ldots$

52

53 meseured Concentrations - Exckground thills

54 ....................

351

56 fonemical unite

571

leckground thells

581

so ins

1....
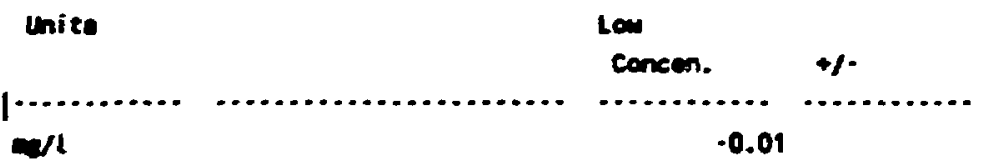
1

2 site mos monament valley, 22, Dechelly

\begin{tabular}{|c|c|c|c|c|}
\hline & |Cr v| & $\boldsymbol{a} / \mathbf{t}$ & -0.01 & \\
\hline $\mathbf{Q}$ & |pb-210 & $\infty \mathrm{xt/l}$ & 0.0 & 1.00 \\
\hline 63 & ino & $0 / 1$ & -0.01 & \\
\hline 4 & inos & $\mathbf{m}$ & -1 & \\
\hline 65 & |Po-210 & $p c i / l$ & 0.0 & \\
\hline 66 & |Ra-226as & $\mathrm{PCi} / \mathrm{l}$ & 0.0 & \\
\hline 67 & ise & $a / l$ & -0.005 & \\
\hline 68 & 1006 & $m / 1$ & 13.2 & \\
\hline 69 & |m-2200 & $p e t / 1$ & 0.00 & 0.30 \\
\hline 70 & 10 & ו & $0 . \times 012$ & \\
\hline$n$ & iv & a & -0.01 & \\
\hline$\pi$ & |ra-22s & $-0 i / l$ & 0.8 & 0.20 \\
\hline$\pi$ & jen-2zs & $0 \mathrm{Ct} / \mathrm{t}$ & 0.0 & 1.10 \\
\hline
\end{tabular}

$74 \ldots \ldots \ldots . . . . . . . . . . . .$.

73

76 calculated werer Intakes - Receptors

$\pi$.......................

7

Adult

Child

Receptor Receptor

conc-met

$(\operatorname{mos} / 1)$

(

(1/ka/dery)

(1/ke/doy)

.............

0.03

0.10

82 ine

0.03

0.10

a fer vi

0.03

0.03

0.10

25 |Pr-210

0.03

0.10

86 |10

0.03

0.10

871003

0.03

0.25

a 1Po-210

0.03

0.10

op jlan-226+6

0.10

90 ise

91 | 100

92 | $\mathrm{m}-220$

93 ju

* 14

95 |Ra-226

96 |Ro-228

97

9

99 calculated theer intakes - Monitor

100 .........................

102 jChmical

1031

104 1...........

105 las

106 led

107 ler VI $\begin{array}{llll}\text { rdult } & \text { Child } & \text { Monitor } & \text { Monitor } \\ \text { In Fector } & \text { In Factor conc-Grose } & \text { Conc-Met } \\ \text { (l/kg/day) } & (1 / \mathrm{kg} / \mathrm{day}) & (\mathrm{ma} / \mathrm{l}) & (\mathrm{m} / \mathrm{l})\end{array}$
0.03

0.03

0.03

0.03

0.03

0.03

0.03

0.10

0.10

0.10

0.10

0.10

0.10

0.10

0.0

1.10

Receptor Receptor Receptor Receptor Adult-Grous thild-Groes Adult-Wet Child-Mot (na/kg/doy) (na/ke/doy) (no/ke/doy) (mo/ko/day)
Monitor

Monitor Monitor

Moniter

Adult-Gross Child-Grose Adult-Met Child-Net (mo/kg/day) (mo/kg/day) (ma/kg/doy) (mo/kg/doy)
0.00

0.00

0.00
0.00

0.00

0.01
0.00

$0 . \infty$

$0 . \infty 0$ 


\begin{tabular}{|c|c|c|c|c|c|c|c|c|}
\hline $19 \operatorname{|ro-210}$ & $0, \infty$ & 0.10 & 1.7 & 1.700 & 0.05 & 0.17 & 0.05 & 0.17 \\
\hline 105 in & 0.06 & 0.10 & 0.3 & 0.200 & 0.01 & 0.16 & 0.01 & 0.06 \\
\hline 110 fass & 0.05 & 0.23 & 0.9 & 8.20 & 0.25 & 2.22 & 0.25 & 2.22 \\
\hline $111 / 00.210$ & 0.03 & 0.10 & 0.6 & 0.400 & 0.01 & 0.06 & 0.01 & 0.06 \\
\hline 113 fse & 0.03 & 0.10 & 0.0 & 0.000 & 0.00 & 0.00 & 0.00 & 0.00 \\
\hline 116 | & 0.03 & 0.10 & c.5.5 & 75.300 & 2.53 & 6.5 & 2.15 & 7.53 \\
\hline
\end{tabular}

2 stite tems: nonument volloy, Az, ouchelly

\begin{tabular}{|c|c|c|c|c|c|c|c|c|}
\hline 115 |Th-20 & 0.08 & 0.10 & 0.5 & 0.500 & 0.01 & 0.00 & 0.01 & 0.05 \\
\hline $116 j u$ & 0.08 & 0.10 & 0.1 & 0.050 & 0.00 & 0.01 & 0.00 & 0.01 \\
\hline $117 \mathrm{fV}$ & 0.01 & 0.10 & 0.6 & 0.600 & 0.02 & 0.08 & 0.02 & 0.06 \\
\hline 118 |Re-226 & 0.6 & 0.10 & 1.5 & 1.500 & 0.04 & 0.85 & 0.04 & 0.15 \\
\hline 119 |Re-22s & 0.08 & 0.10 & 0.0 & 0.000 & 0.00 & 0.6 & 0.00 & 0.00 \\
\hline
\end{tabular}

121

122 colculeted atake - abehrente

123 ..............

$126 \mid$ Ats

125 fthmical Toxicity Receper Receptor Receptor

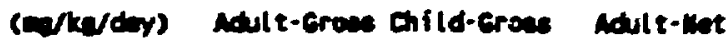

Recepter monitor moniter moniter monitor Child-bet Adult-Grow Child-Erose ndult-net Child-wat 127 [.........

120 ine $1.40 E-05$

129 jed 1.20E-0s

130 |cr $n$

$131 \mid \kappa-210$

132 ino

$133 \operatorname{lnos}$

134 [Po-210

135 itie-2ects

130 15e

137 1206

139 | $\mathrm{Th}-20$

139 |U

$140 \mathrm{IV}$

161 |Ra-226

142 |Re-228

$143 \ldots \ldots . . . . . .$.

146

145 Calaulated Riske - Errenic

166 ..............

167 AIC

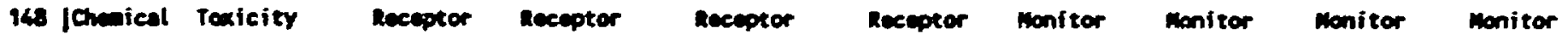
169 $1501 \ldots \ldots . . . . .$.

$1.10 \leq+01$

?.

$3.20 z-03$ (ng/ky/dy) Adult-Groes child-Groes ndult-wet

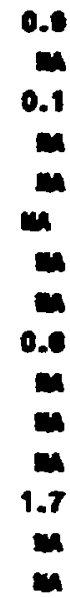

$1.60 E-03$

2.90e-0s

$5.00 E \cdot 05$

2.90E-0B
0.0

0.3

0.3

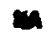

2.6
0.1

0.3

m

$\mathbf{m}$

us

0.2

$m$

m

m

$m$

แม

แต

6.0

M

m
Adult-Gros

Child-Groes Adult-net
0.0

a

0.1

m

$m$

u

w

$m$

0.0

m

w

w

1.7

$m$

m

\begin{tabular}{|c|c|c|}
\hline & As & $1.60 z-03$ \\
\hline & ICd & 2.90E-0s \\
\hline 153 & fCr vi & $5.005 \cdot 00$ \\
\hline 154 & |Pb-210 & \\
\hline 155 & | & $2.905-103$ \\
\hline
\end{tabular}




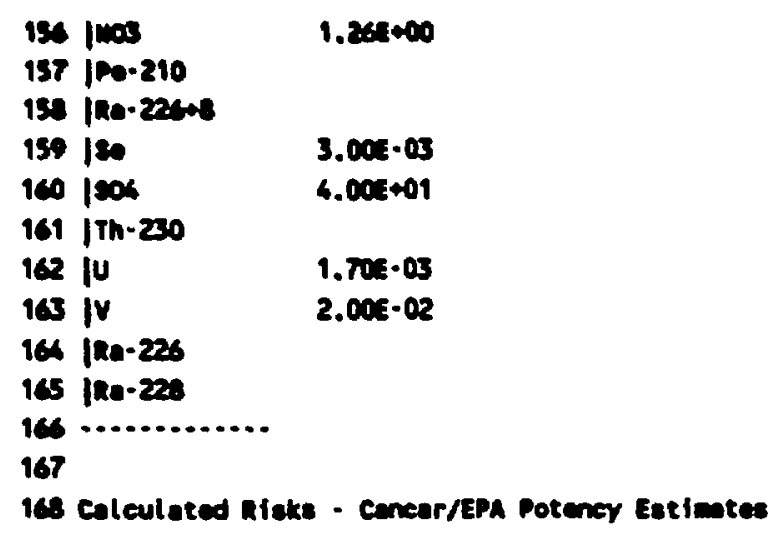

1

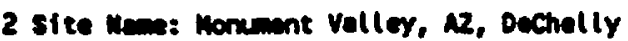

169 ..............

170

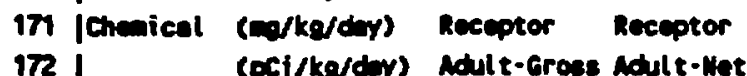
$173 \mid \ldots \ldots . . . .$.

174 las

175 jed

$1.50 E+01$

$176 \operatorname{lcr} v$

177 |Pb-210

170 |10

179 [nos

180 Pि-210

181 [ne-226+8

182 ise

183 lsos

ist |th-230

105 Ju-nat

186 IV

187 /ne-226

186 Jna-220

189 ..............

190

191 Colculated Riske - Cencer/1Csp Potency Estimtes

$192 \ldots . . . . . . .$.

193

196 |Chenical ( $0 / \mathrm{kg} / \mathrm{day})$ Receptor Receptor 195 $196 \mid \ldots \ldots . . . . .$.

197 las

198 led

199 ICr VI

200 |Pb-210

MA

MA

$1.40 E-06$

in

M

3.6ez-04

M

M

7.70E-05

4.73E-05

ma

3.005-06

2.31E-04
0.2
0.2

in

m

0.0

$m$

$m$

0.8

0.9

M

$m$ a

$m$

$m$

an

0.2

$m$

3.0

w

$m$

m

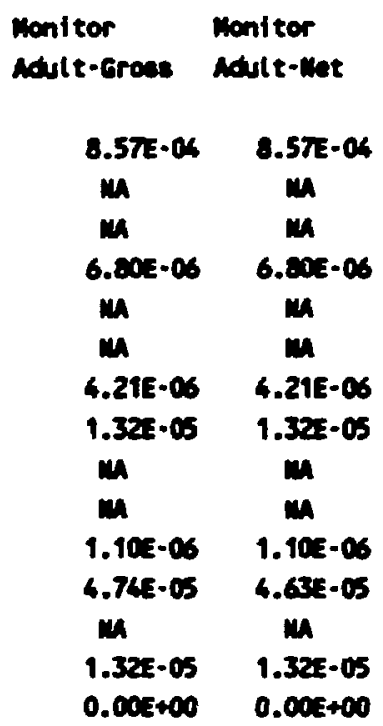

201 |no

202 |1003

203 100-210 (pel/kg/dy) Adult-Groes Groes-Het

\begin{tabular}{|c|}
\hline $1.50=+01$ \\
\hline$m$ \\
\hline$\stackrel{M}{1.14 E-03}$ \\
\hline $\begin{array}{l}1.14 E-03 \\
\mathrm{~m}\end{array}$ \\
\hline$m a$ \\
\hline
\end{tabular}

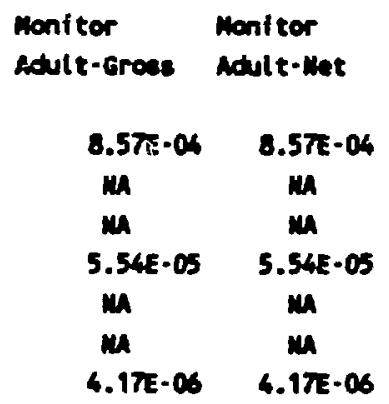


20 fro-22en

205 150

ats 100

207 Im-20

20 ju-nat

20 |V

210 |Ra-22s

211 |Re-224

$212 \ldots \ldots \ldots \ldots$ $m$

$m$

$1.112 \cdot 04$

5.6et-os

M

$2.47 \cdot 04$

$2 . \pi 7 \cdot 06$ 1.001-0s 1.002.08

m

M M

1.6n.0s 1.cin.0s

s.5et-os 5.37 .05

$\mathrm{M}$

1.005-0s 1.06e-0s

$0.005+\infty 00.006+\infty 0$ 


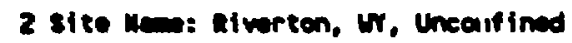

7 mecured concentrations - Receptor unlls

6.................... .................

$\rightarrow 1$

10 jenmical Units

RECEPTOR VELLS

111

12

13 las

Migh

concen. $\quad+1$ -

16 lad

15 jer vi

16 | 10 - 210 pci/l

17 ino

18 inos

19 PPo.210 pCi/l

20 |Ro-226+8 $\mathrm{pCi} / \mathrm{l}$

21 lse

22 1004

23 /Th-230 pCI/l

26 ju

25 iv

26 |Ra-226 $\mathrm{Ci} / \mathrm{l}$

27 /Re-228 DCI/l

2.

29

30 nessured Concentrations - Monitor walls

31

32

3 fohwienl Units

36

35

36 in

37 led

38 jer vI

39 1ro-210

40 ins

$61 \operatorname{lmas}$

$42100-210$

..............

Fill

it ise nert

45 150\% art

66 Ith-230 peift

$47 \mathrm{jo}$

46 IV art

49 jne-226 pij/l

monitor Wells

uigh

concen. $\quad+\%$

50 [no-228 pei/l

51

52

53 moweured concentrations - ceckground walls

56 JChenical Units

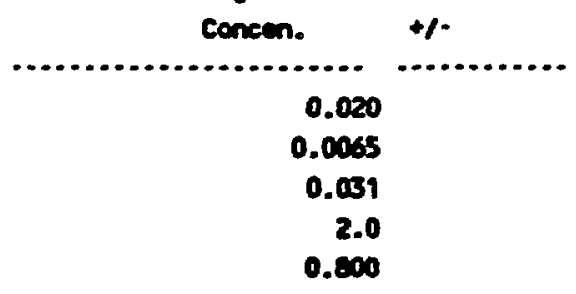

10.5

0.2

0.127

6000

2.300

0.010

0.2

..............

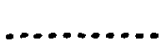


2 site mo: Riverten, $M$, Unconfined

\begin{tabular}{|c|c|c|c|c|}
\hline $61 \mathrm{JCr}$ VI & $m$ & $\cdot 0.01$ & & -0.01 \\
\hline $62 \mid \omega-210$ & $\mathrm{Ext/1}$ & 0.90 & 0.60 & -1.5 \\
\hline $631 \%$ & $n$ & 1.38 & & -0.01 \\
\hline$\Leftrightarrow \ln n$ & $a / l$ & 13.00 & & -0.1 \\
\hline 65 |Po-210 & $\mathrm{Pi} / \mathrm{l}$ & 0.10 & 0.60 & 0.0 \\
\hline 66 |Re-226n8 & $\mathrm{Pl} / \mathrm{t}$ & 0.2 & & 0.0 \\
\hline 67 IEe & $\mathrm{ert}$ & 0.005 & & -0.005 \\
\hline 68 IEOs & $\mathrm{nrt}$ & 582 & & 3 \\
\hline 69 |Th-230 & pet/l & 0.5 & 0.6 & $\cdot 1$ \\
\hline $70 \mid u$ & $c / 1$ & 0.0156 & & $\cdot 0.000$ \\
\hline$n \mathrm{lv}$ & $=11$ & 0.04 & & $\cdot 0.01$ \\
\hline $72 \mid 10-226$ & pill & 0.2 & 0.2 & 0.0 \\
\hline is |lle-22s & $\mathrm{pit}_{1}$ & 0.00 & 0.90 & 0.00 \\
\hline
\end{tabular}

\section{$\pi$.......................}

\begin{tabular}{|c|c|c|}
\hline $\begin{array}{l}78 \text { | } \\
79 \text { |chenical } \\
601\end{array}$ & $\begin{array}{l}\text { Adult } \\
\text { In Fector } \\
\text { (t/ke/dy) }\end{array}$ & $\begin{array}{l}\text { Child } \\
\text { In fector } \\
\text { (M/ke/dry }\end{array}$ \\
\hline Ins & 0.03 & 0.10 \\
\hline 83 JCA & 0.03 & 0.10 \\
\hline $86 \mathrm{JCr} V I$ & 0.06 & 0.10 \\
\hline es | & 0.103 & $0_{n} 10$ \\
\hline 86 llio & 0.06 & 0.10 \\
\hline 871103 & 0.03 & 0.25 \\
\hline $\mid \operatorname{lo-210}$ & 0.03 & 0.10 \\
\hline 89 1no-22s+8 & 0.03 & 0.10 \\
\hline 90 ISe & 0.03 & 0.10 \\
\hline $91 ! 506$ & 0.03 & 0.10 \\
\hline $\mid x-20$ & 0.63 & 0.10 \\
\hline & 0.03 & 0.10 \\
\hline 94 IV & 0.03 & 0.10 \\
\hline 95 |Re-226 & 0.03 & 0.10 \\
\hline |Re-223 & 0.03 & 0.10 \\
\hline
\end{tabular}

9

99 Colculated water Intakes - Monitor

10

1011

102 |chmicat

103 ।

1041

105 las

106 led

107 ICr vI
Adult

In Fector (l/ke/dy) child Monitor

In Fector Conc-Gross

(l/kg/day) (mo/l)

(n.............

Receptor (a)/1) conc- wet
Receptor Reciptor Receptor Receptor Adutt-Groes Child-Groes Adut t-liet child-ilet

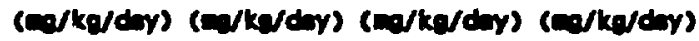




\begin{tabular}{|c|c|c|c|c|c|c|c|c|c|}
\hline 10 & |R-210 & 0.06 & 0.10 & 2.0 & 2.000 & 0.06 & 0.20 & 0.06 & 0.20 \\
\hline 109 & ino & 0.03 & 0.10 & 0.8 & 0.200 & 0.02 & 0.00 & 0.02 & 0.06 \\
\hline 110 & 1003 & 0.03 & 0.25 & 10.5 & 10.500 & 0.30 & 2.63 & 0.30 & 2.13 \\
\hline 111 & 100.210 & 0.03 & 0.10 & & & & & & \\
\hline 112 & | $120-226+8$ & 0.03 & 0.10 & 0.2 & 0.200 & 0.01 & 0.02 & 0.01 & 0.02 \\
\hline 113 & |se & 0.03 & 0.10 & 0.1 & 0.127 & 0.00 & 0.01 & 0.00 & 0.01 \\
\hline 116 & 1000 & 0.03 & 0.10 & 6000.0 & 5967.000 & 171.42 & 600.00 & 170.48 & $5 \% .70$ \\
\hline
\end{tabular}

1

2 stee Name: Riverton, Ur, Unconf ined

\begin{tabular}{|c|c|c|c|c|c|c|c|c|}
\hline 115 |Th-230 & 0.03 & 0.10 & 13.0 & 13.000 & 0.37 & 1.30 & 0.37 & 1.30 \\
\hline 116 ju & 0.03 & 0.10 & 2.3 & 2.300 & 0.07 & 0.23 & 0.07 & 0.23 \\
\hline 117 IV & 0.03 & 0.10 & 0.0 & 0.010 & 0.00 & 0.00 & 0.00 & 0.00 \\
\hline $118 \mid R=-226$ & 0.03 & 0.10 & 0.2 & 0.200 & 0.01 & 0.02 & 0.01 & 0.02 \\
\hline
\end{tabular}

120 ....................................

121

122 Calculated Risks - subchronic

123 .............

126 | AIs

125 /Chelical Taxicfty Receptor Receptor Receptor (no/kg/dor) Adule-Grose child-Grose Adult-Met

Aeceptor Monitor Monitor Monitor Monitor Child-Met Nult-Grose child-Groses Adult-wet Child-Met

$1.40 E-03$

1.20E-03

$2.50 \mathrm{E}-02$

129 jed

0.4

1.4

0.4

m

0.5

in

0.0

m

0.0

in

us

m

a

m

un

1.10E+01

$\boldsymbol{m}$

0.2

$M$

0.2

136 |Po-280

$\begin{array}{rrr}m & m & m \\ 1.1 & m & 1.1 \\ m & m & m \\ m & m & m \\ m & m & m \\ m & 0.1 & 0.0 \\ m & m & m\end{array}$

135 the-226+8

$3.20 E-03$

137 100\%

138 (Th-230

13910

$160 \mathrm{~N} \quad 1.00 \mathrm{~V}-02$

149 |ha-226

142 the-228

$163 \ldots \ldots \ldots$.

166

165 Colculated Risks - Chronic

146 .............

147 AIC

148 IChemical Toxicity Receptor Receptor Receptor 149

1501

151 IAs

(calkg/doy) Adult-Grose Child-Gross Adult-Het

Receptor Monitor

monitor Monitor

Monitor 152 jed

$1.40 E-03$

2.90E-04

5.00E-03

Child-lyet

Adult-Groes Child-Groes Adult-Met

child-wer

153 ICr VI

156 |Pb-210

155 [No

$2.90 E \cdot 03$

$\begin{array}{rrr}0.6 & 1.6 & 0.4 \\ 0.6 & 2.2 & 0.6 \\ 0.2 & m & 0.2 \\ M & m & m \\ 7.9 & 27.6 & 7.9\end{array}$




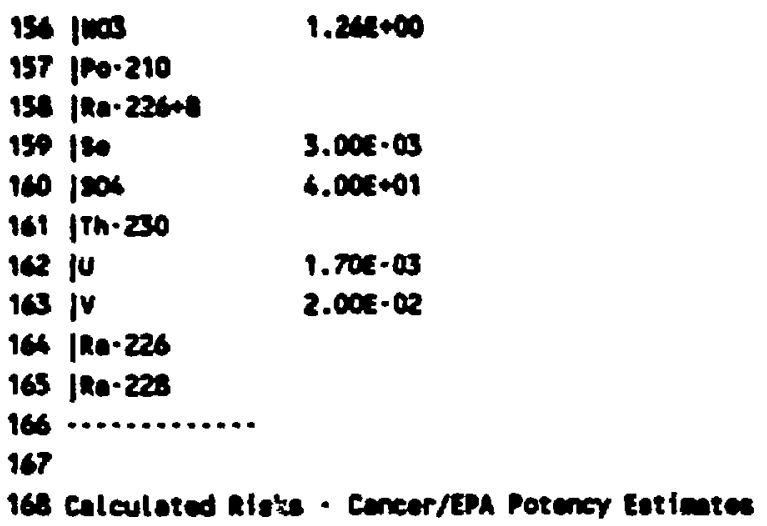

I

2 site mans: Riverton, $w$, Unconf ined

$160 . . . . . . . . .$.

17 | potensy

I7 fchoieal

1721

$173 \mid \ldots \ldots . . .$.

174 jas

$17 \mathrm{~s}$ |cd

176 |Cr vI

itr |ro-210

178 ins

179 1003

100 | $10-210$

181 |ka-22648

182 |se

183 las

$18 \mathrm{ITh}-220$

IS fu-net

$18.6 \mathrm{IV}$

187 |lan-226

18. |lie-2as

$189 . . . . . . . . .$.

190

191 colculoted Riaks - Concer/lcep Potency Estimtes

192 .............

193 I Potency

194 |Chroied

195 I

196 1...........

197 IAs

198 led

199 |er vi

$200 \mid \mathrm{rb}-210$

201 j160

$202 \operatorname{lnos}$

201 po-210

(an/ke/dor) Recepter Receptor Monitor Monitor

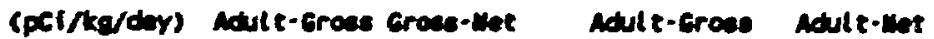

$\begin{array}{lcc}1.502+01 & 8.57 E \cdot 03 & 8.5 \pi \cdot 03 \\ m & m & m \\ m & m & m \\ 1.60 E-04 & 8.00 E \cdot 06 & 8.00 E-05 \\ m & m & m\end{array}$

3.6re-ch

m

$7.705-05$

4. BSE-0s

M

3.0.E-C4

2.31E-OH monitor meniter

adult-Graes roult-Wet

1.7ce-06 1.76e-06

M m

a

2.86E-05 2.86z-05

2.12E-03 2.12z-03

M

$1.76 E-06 \quad 1.76 E-06$

$0.00 E+\infty 00 \quad 0.005+00$
0.2

$m$

1.2

$m$

$m$

3.7

0.0

$m$

$m$

wa

0.2

$m$

15.0

w

135.3

in

$m$

$m$

in

1.2

m

M

33.7

0.0

un

m

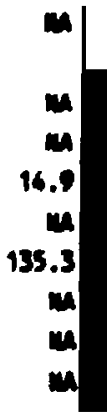


204 |100-22006

200

2001004

207 in.230

200 ju-nat

209 IV

210 |ken-226

211 |Ro-223

212 .............. m

M

1. $15 x \cdot 06$

$5.69 \cdot 05$

Ma

$2.6 \pi \cdot 04$

$2 . m \cdot 04$
$1.616-04 \quad 1.416 \cdot 05$

$m$

m in

$4.340 .05 \quad 6.340 .05$

$2.468 .03 \quad 2.66 E .03$

ma

$1.61 E .06 \quad 1.41 E .06$

$0.00 E+\infty 0 \quad 0.00 E+\infty 0$ 
1

2 sfte Hen: Aiverten, $\mathbf{m}$, conflind

7 meacured concentretion - neceptor wills

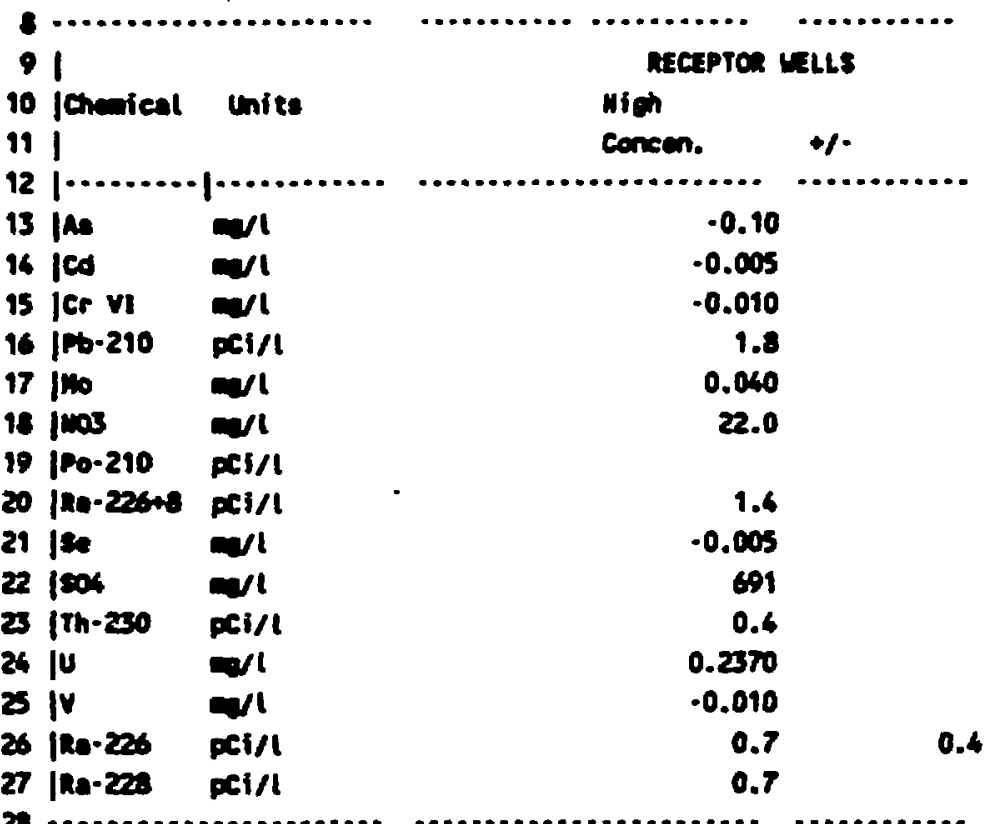

20

\section{2}

30 meseured Concentration - monitor walls

31

321

33 lareried units

moniror untle

341

351

34 Ins

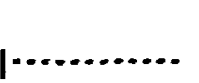

uteh

37 jed mat

38 ler VI

mall

$39 \mid+b-210$

m/l

pist

60 tho

61 Inos

42 |Po-210 pis

43 Ino-zach pill

4 fse $\mathrm{n} / \mathrm{l}$

45 Isas nos

46 ITh-230 peifl

$67 \mathrm{ju} \quad \mathrm{m} / 1$

48 IV

ati

49 |na-2as pi/l

50 line-zas pet/l

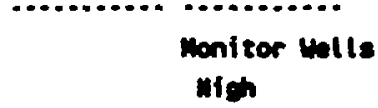

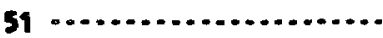

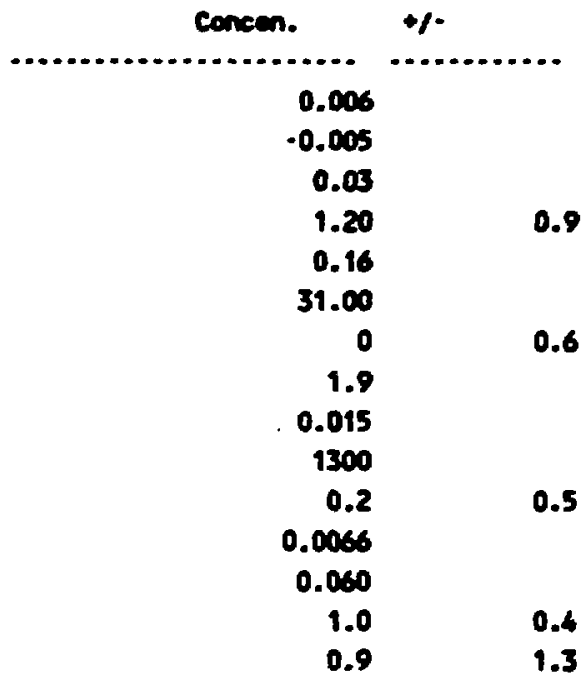

52

53 masured concentratione - Neckground wells

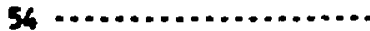

551

56 johemieal unite

ecterground walls

57

581

59 ine

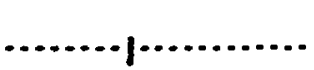

Concen.

$\bullet$

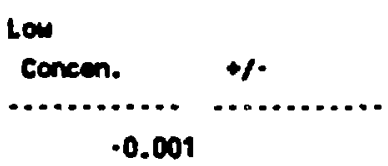


1

2 site una Riverton, $w$, Confinad

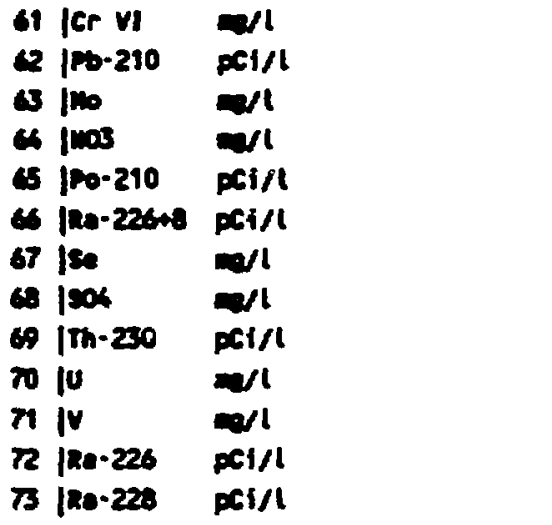

76 ........................

is

76 colculated werer Intekes - Receptors

$\pi$

7.

79 fchemieal

01

81 1 $1 \ldots \ldots . . .$.

2 ins

a ica

Q4 ICr vI

$8 / \mathrm{b}-210$

es 1mo

8 lnos

c) |ro-210

o8 pan-226+8

90 15e

91 low

$\%$ Ith-230

\% $\mid v$

94 IV

95 1na-226

\% |na-220

$\varphi$

9

9 colculated water Intckes - noniter

10

101

102 f themieal

1031

104

itos fits

jos jed

note

child

neceptor

conc-sroes

(trageders

In flector conc-area

0.08

0.03

0.03

0.03

.0 .03

0.03

0.03

0.03

0.03

0.03

0.03

0.03

0.03

0.03

0.03 .............

\subsection{0}

0.10

0.10

0.10

0.10

0.25

0.10

0.10

0.10

0.10

0.10

0.10

0.10

0.10

0.10 adute

In fector

(I/ke/dy) child

in fector

(1/ke/duy)

nonitor

conc-Gross

(nopli)

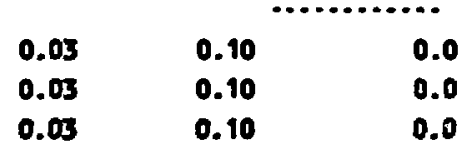

$$
-0.001
$$

0.0

$-0.001$

$-0.1$

0.0

$-1.0$

$-0.002$

80.3

0.0

$-0.0003$

$-0.005$

$-1.0$

$-1$
1.3

0.0004
Receptor Receptor neceptor Inceptor Reeptor conc-iwet Adult-Groes child-croes ndult-wet child-inet (a)/i)

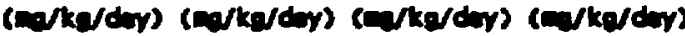

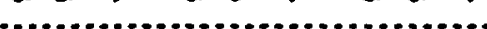

$\begin{array}{rrrr}0.00 & 0.00 & 0.00 & 0.00 \\ 0.00 & 0.00 & 0.00 & 0.00 \\ 0.00 & 0.00 & 0.00 & 0.00 \\ 0.05 & 0.18 & 0.05 & 0.18 \\ 0.00 & 0.00 & 0.00 & 0.00 \\ 0.03 & 5.50 & 0.63 & 5.50 \\ 0.04 & 0.34 & 0.04 & 0.14 \\ 0.00 & 0.00 & 0.00 & 0.00 \\ 19.74 & 69.10 & 17.45 & 61.07 \\ 0.01 & 0.06 & 0.01 & 0.06 \\ 0.01 & 0.02 & 0.01 & 0.02 \\ 0.00 & 0.00 & 0.00 & 0.00 \\ 0.02 & 0.07 & 0.02 & 0.07 \\ 0.02 & 0.07 & 0.02 & 0.07\end{array}$

monitor (ing)

\begin{tabular}{|c|c|c|c|}
\hline $\begin{array}{l}\text { Monitor } \\
\text { Adult - Grose } \\
\text { (a/kg/day) }\end{array}$ & $\begin{array}{l}\text { moniter } \\
\text { chitd-Groes } \\
\text { (no/ke/der) }\end{array}$ & $\begin{array}{l}\text { moniter } \\
\text { ndutt-inet } \\
\text { (ma/ko/dar) }\end{array}$ & $\begin{array}{l}\text { monitor } \\
\text { Child-int } \\
\text { (mo/kg/dor) }\end{array}$ \\
\hline 0.00 & 0.00 & 0.00 & 000 \\
\hline 0.00 & 0.00 & 0.00 & 0.00 \\
\hline 0.00 & 0.00 & 0.00 & 0.00 \\
\hline
\end{tabular}




\begin{tabular}{|c|c|c|c|c|c|c|c|c|}
\hline 100 | $10 \cdot 210$ & 0.08 & 0.10 & 1.2 & 1.200 & 0.05 & 0.12 & $0 . \infty$ & 0.12 \\
\hline 100 ine & 0.08 & 0.10 & 0.2 & 0.160 & $0 . \infty 0$ & 0.02 & $0 . \infty$ & 0.02 \\
\hline 110 & 0.08 & 0.25 & 31.0 & 31.000 & 0.80 & 7.75 & 0.0 & 7.7 \\
\hline 111 |P0.210 & 0.06 & 0.10 & 0.0 & 0.000 & $0 . \infty$ & 0.00 & $0 . \infty$ & 0.00 \\
\hline 112 |100-22048 & 0.03 & 0.10 & 1.9 & 1.900 & 0.05 & 0.19 & 0.05 & 0.19 \\
\hline 113 iso & 0.08 & 0.10 & 0.0 & 0.013 & 0.00 & 0.00 & $0 . \infty$ & 0.00 \\
\hline $116 / 1006$ & 0.08 & 0.10 & 1300.0 & 1219.700 & 37.16 & 130.00 & 34.8 & 121.7 \\
\hline
\end{tabular}

\begin{tabular}{|c|c|c|c|c|c|c|c|c|}
\hline \multicolumn{9}{|c|}{ rton, in, comfind } \\
\hline 115 |m-200 & 0.08 & 0.10 & 0.2 & 0.200 & 0.01 & 0.02 & 0.01 & 0.02 \\
\hline 11610 & 0.08 & 0.10 & 0.0 & 0.007 & 0.00 & 0.00 & 0.00 & 0.00 \\
\hline 197 IV & 0.03 & 0.10 & 0.1 & 0.060 & 0.00 & 0.01 & 0.00 & 0.08 \\
\hline 118 [110.226 & 0.03 & 0.10 & 1.0 & 1.000 & 0.03 & 0.10 & 0.08 & 0.10 \\
\hline 119 ten-223 & 0.03 & 0.10 & 0.9 & 0.900 & 0.05 & 0.08 & 0.03 & 0.00 \\
\hline
\end{tabular}

120

121

122 colculoted riske - ubchrentic

$123 . . . . . . . . .$.

126 I Ais

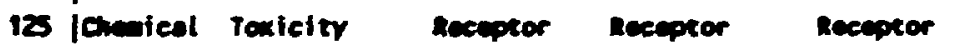

1261 (Co/ke/dey) ndut-eroes child-erows ndult-wet

aceaptor Moniter monitor Moniter

moniter

$1271 \ldots . . . . . .$.

12010

$1.602-03$

0.0

$0.0 \quad 0.0$

child-wet

ndult-erese child-erese nulte-wet

child-wat

129 led

130 jer $\forall:$

131 | $10-210$

132 110

1331008

136 | 10.210

IS5 |20-225

136 ise

137 |

$1301 \mathrm{mh}-230$

130 ju

160 |Y

16) ina.220

162 par-220

$143 \ldots \ldots \ldots$

144

145 colarlated Risks - Ehronic

165 .............

467 AIC

148 fonerieat Touicity 1891

$150 \mid \ldots . . . .$. (manger)

2.50z-62

m.

0.0

0.0

in

$m$

$1.10 E \div 01$

$m$

$m$

u

$m$

$3.200 \cdot 03$

m

0.0

$m$

1.cis-n

a

0.5

$m$

$m$

\begin{abstract}
0.0
0.0

$m$

$m$

$m$

0.5
\end{abstract}

$m$

$m$

$m$

$m$

ma

0.0

$m$

w.
0.1

0

$m$

$m$

m

$m$

m

0.1

$m$

$m$

w

0.2

$m$

$m$
0.4
0.0
$m$
$m$
$m$
$m$
$m$
$m$
$m$
$m$
$m$
0.1

w

0.0

in

w

บิ

m

m.

0.1

wa

m

$m$

0.2

as

w
151 the

152 lad

153 ler vi

154 int-210

155 1no

$1.40 E-03$

$2.905-04$

$5.006-03$

$2.906-03$
Receptor Receptor ieceptor idult-Grose Child-Gross ndult-Wet
Receptor Enild-met nonitor monitor Adult-Erose child-Groes adult-met monitor child-wet 


\begin{tabular}{|c|c|c|}
\hline 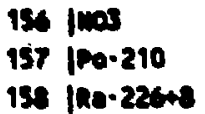 & $1.245+60$ & 0.5 \\
\hline ise ise & $3.005-03$ & 0.0 \\
\hline 160 isos & $4.002+01$ & 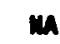 \\
\hline 161 | Th-230 & & $M$ \\
\hline 162 Wu & $1.702-03$ & 4.0 \\
\hline $163 \mathrm{IV}$ & $2.00 E-02$ & 0.0 \\
\hline 164 |he-226 & & $\mathbf{M}$ \\
\hline 165 |Re-220. & & $\boldsymbol{M}$ \\
\hline
\end{tabular}

$\mathbf{0}$

.5

0.7

$m$ m M

1

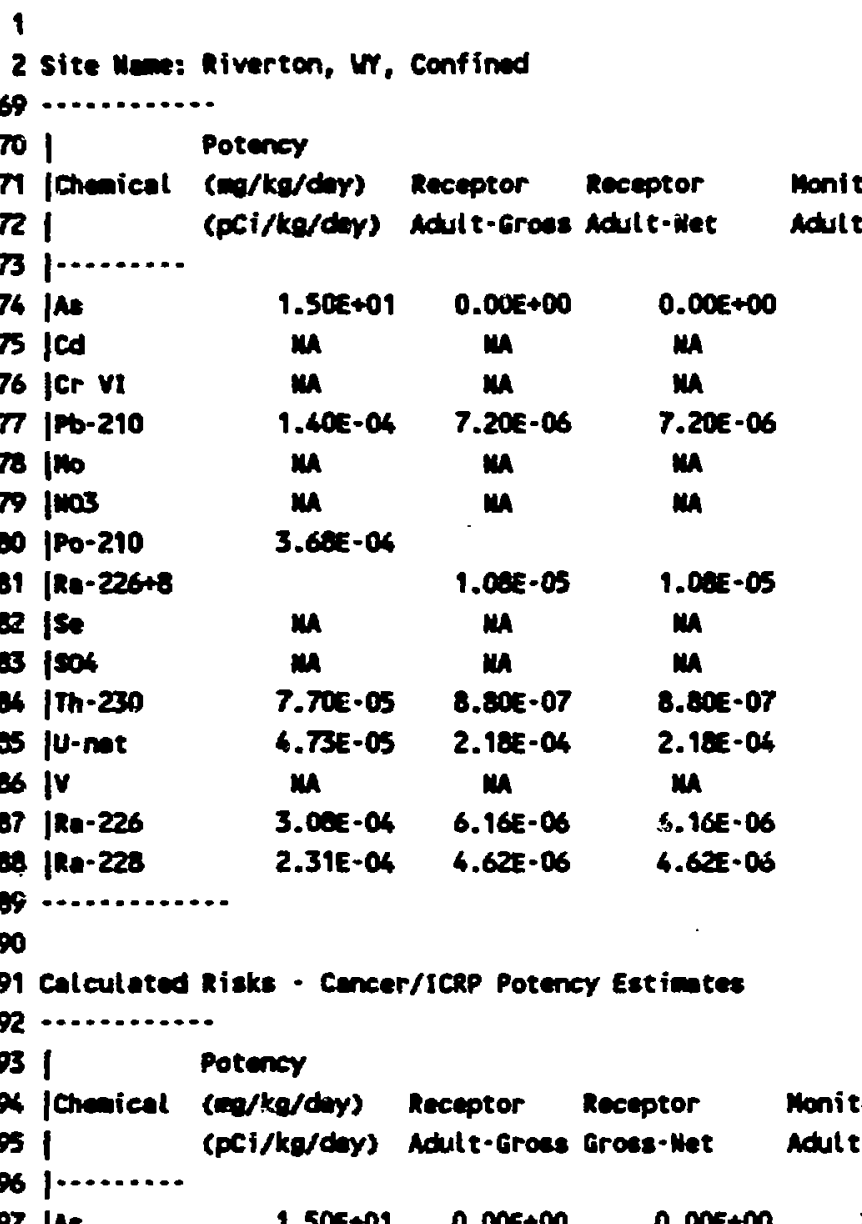

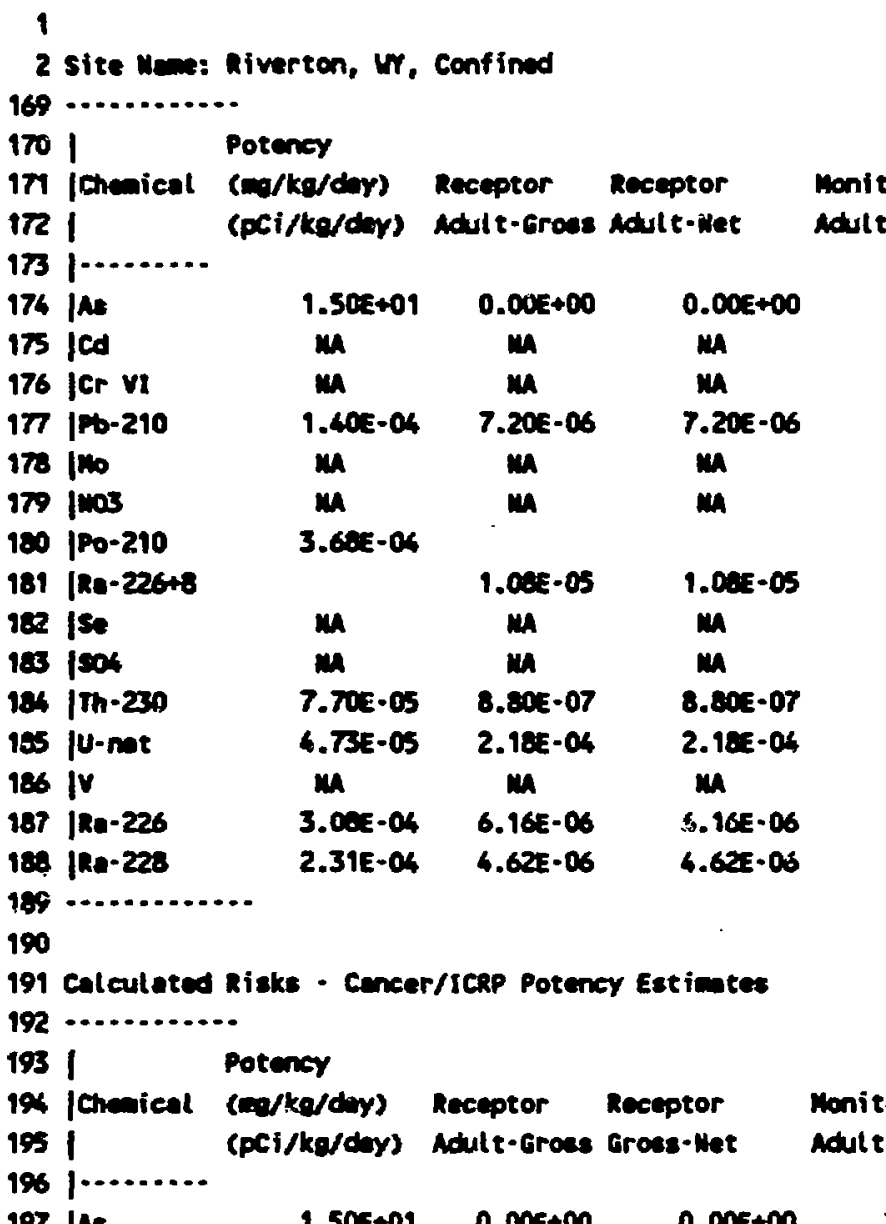

\begin{tabular}{|c|c|c|c|c|c|c|}
\hline $\begin{array}{l}170 \\
171 \\
172\end{array}$ & I Inemical & $\begin{array}{l}\text { Potency } \\
(m / k g / d y) \\
\text { (pci/ke/dor) }\end{array}$ & $\begin{array}{l}\text { Receptor } \\
\text { idult-Grose }\end{array}$ & $\begin{array}{l}\text { Receptor } \\
\text { idult -wet }\end{array}$ & $\begin{array}{l}\text { Monitor } \\
\text { Adutt-Gross }\end{array}$ & $\begin{array}{l}\text { Monitor } \\
\text { Motult-Mat }\end{array}$ \\
\hline & $\cdots$ & & & & & \\
\hline & Int & $1.50 E+01$ & $0.00 E+00$ & $0.00 E+\infty 0$ & $2.57 \mathrm{E}-03$ & $2.5 \pi-03$ \\
\hline & Icd & $m$ & $m$ & $\mathbf{m}$ & $m$ & $m$ \\
\hline & ICr Vt & $m$ & $m$ & $m$ & $m$ & $m$ \\
\hline & |rb-210 & $1.40 E-04$ & $7.205-06$ & $7.20 E-06$ & $4.805-06$ & 4.80E-06 \\
\hline & $1 n_{0}$ & $\boldsymbol{M}$ & $m$ & $m$ & $m$ & $m$ \\
\hline & 1003 & $M$ & $m$ & $m$ & $m$ & $m$ \\
\hline & |Po-210 & $3.6 \times 2-04$ & & & $0.00 \leq+00$ & $0.02=+00$ \\
\hline & [Re-226+8 & & $1.005-05$ & $1.005-05$ & $1.67 E-05$ & $1.67 t-05$ \\
\hline & 1se & $m$ & $\mathbf{m}$ & $m$ & $m$ & $m$ \\
\hline & 19ot & $m$ & $m$ & $m$ & $m$ & $m$ \\
\hline & ITh-220 & $7.705 \cdot 65$ & 8.8xe-07 & $8.80 E-07$ & $6.405-07$ & $6.405-07$ \\
\hline & |U-nat & $6.73 E-05$ & $2.18 t-04$ & $2.18 c-04$ & 6.00E-06 & 6.10es-06 \\
\hline & IV & $m$ & $m$ & $m$ & $m$ & $M$ \\
\hline & |Ra- & $3.00=-04$ & $6.165-06$ & $5.16 E-06$ & B.80E-06 & $8.80 E-06$ \\
\hline & |Ro-220 & $2.31 E-04$ & $4.62 E-06$ & $4.625 \cdot 06$ & 5.94E-06 & $5.96 E-06$ \\
\hline
\end{tabular}

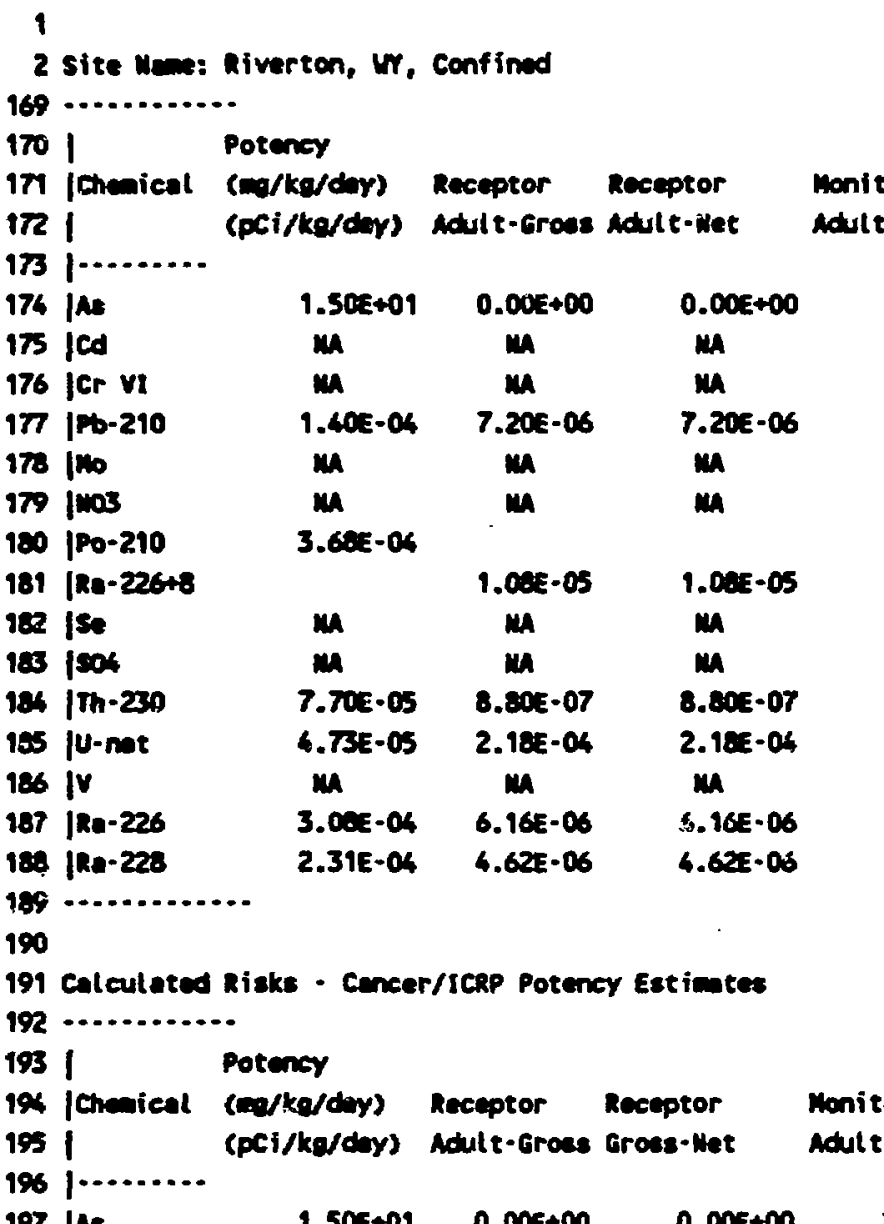

190

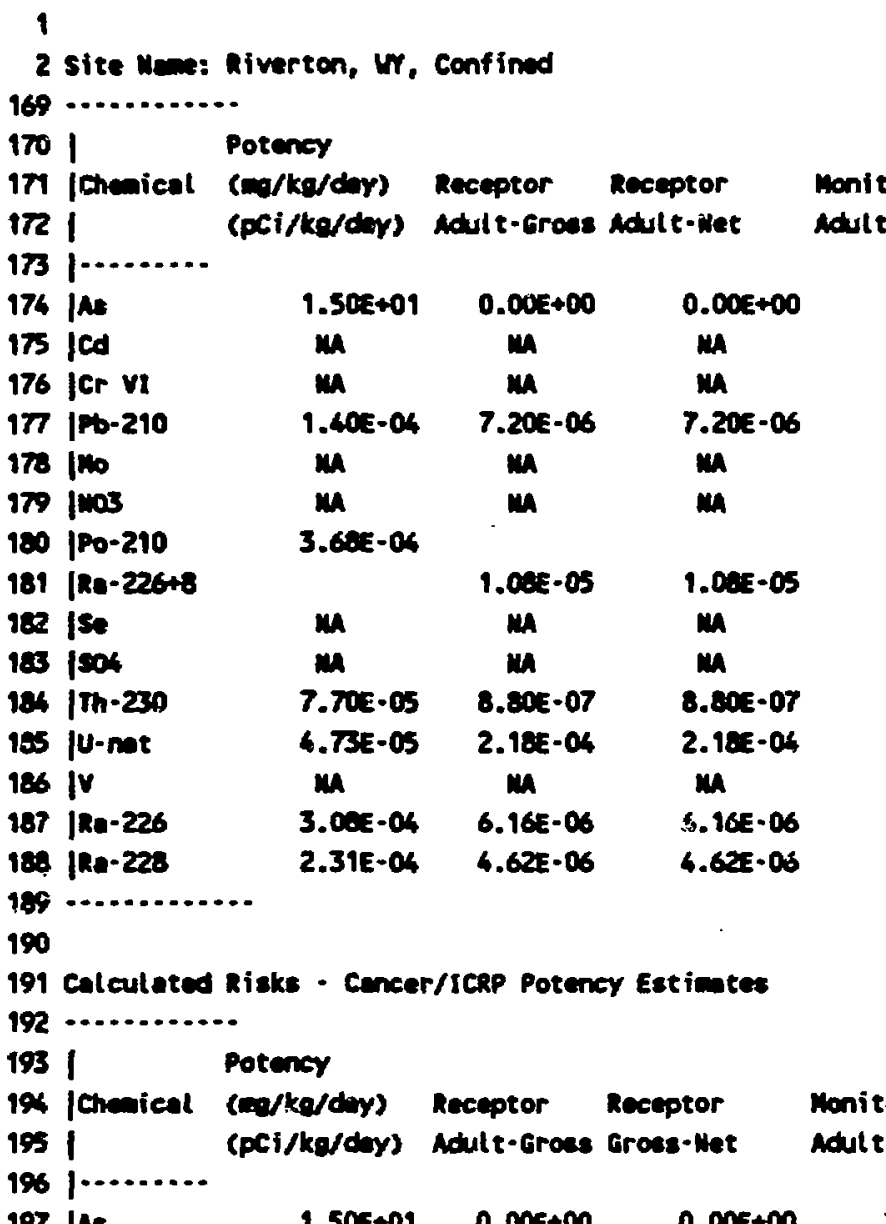

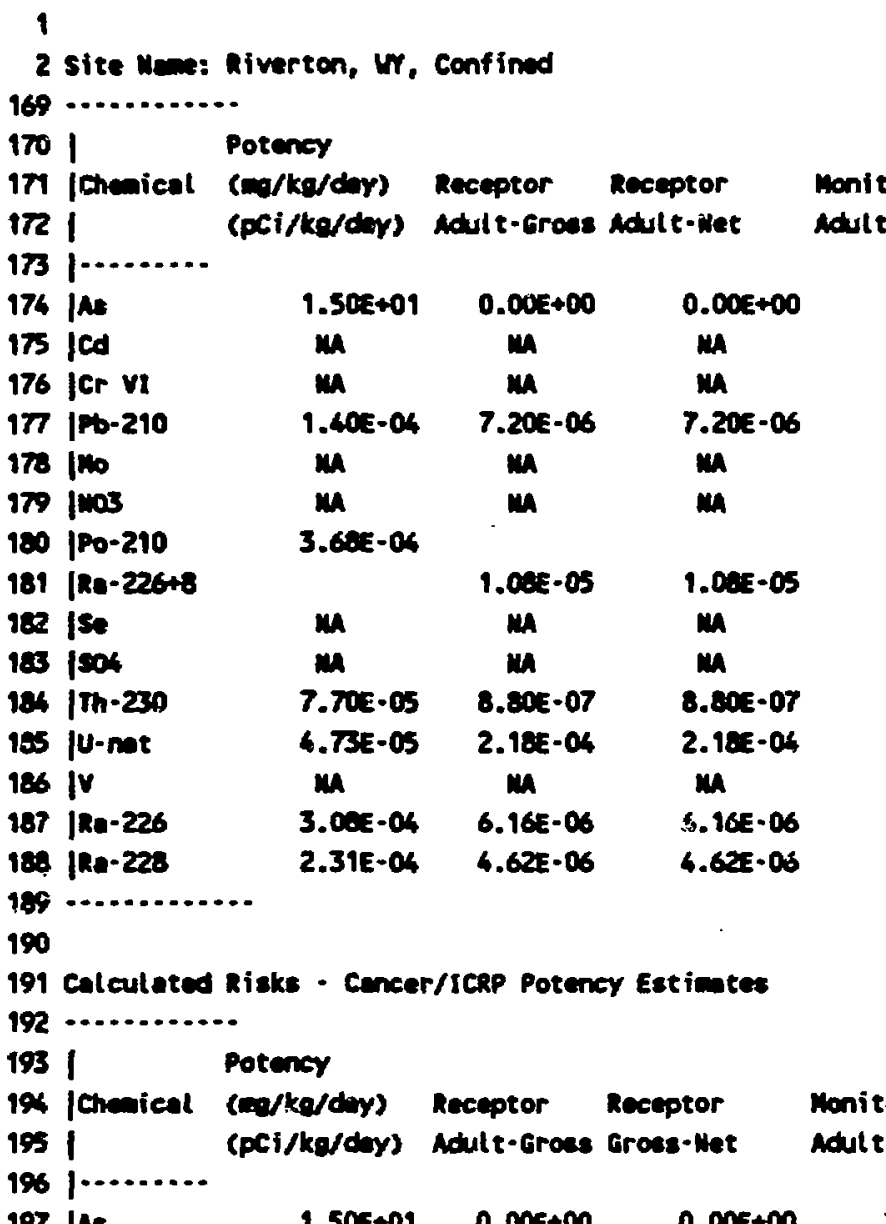

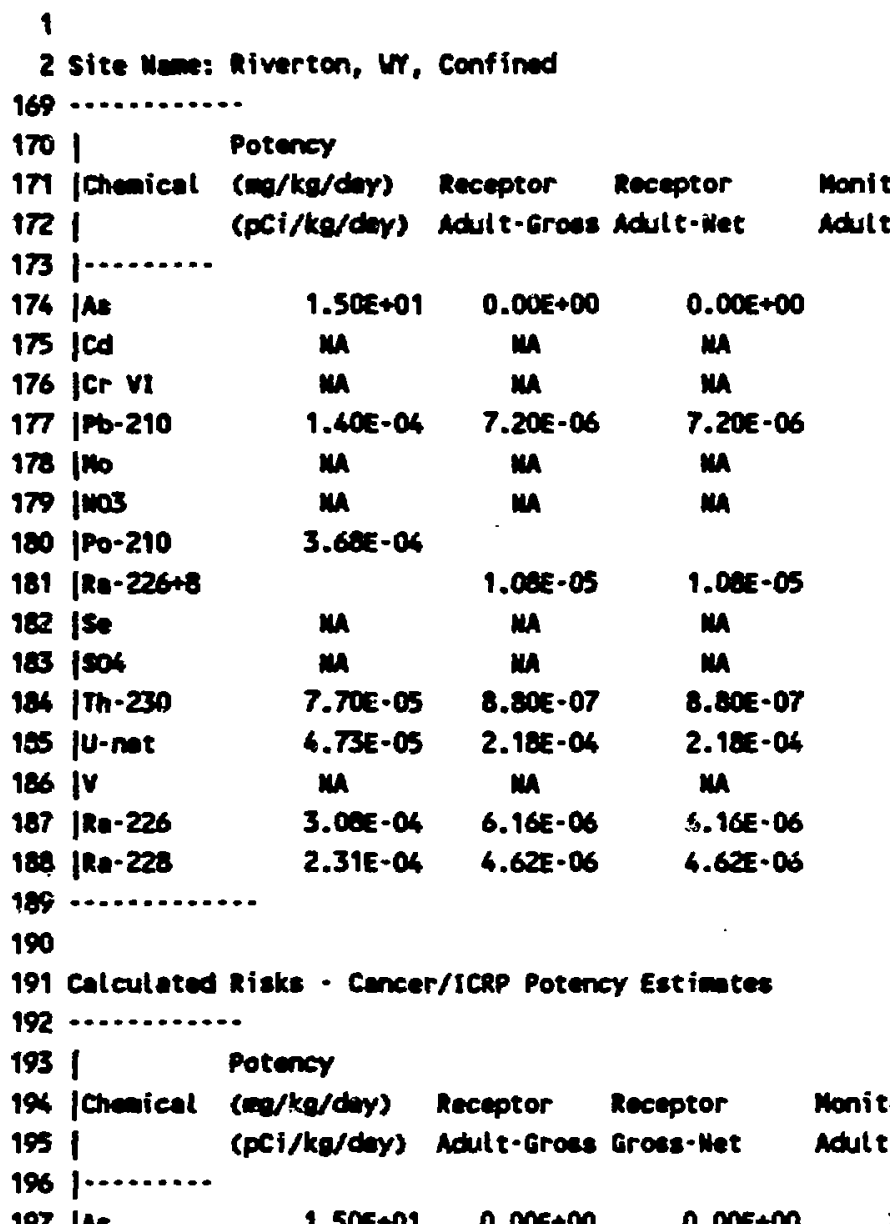

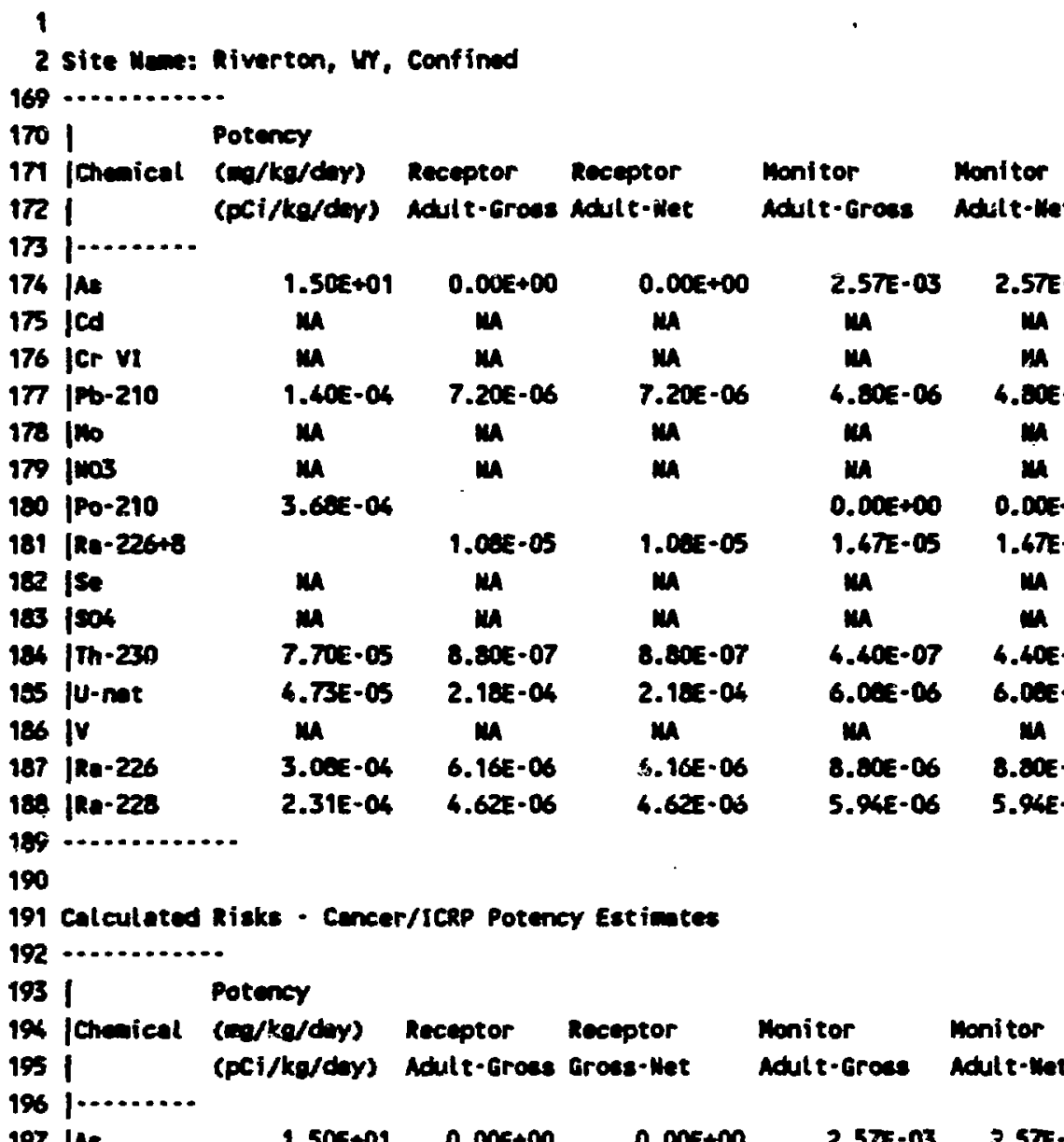

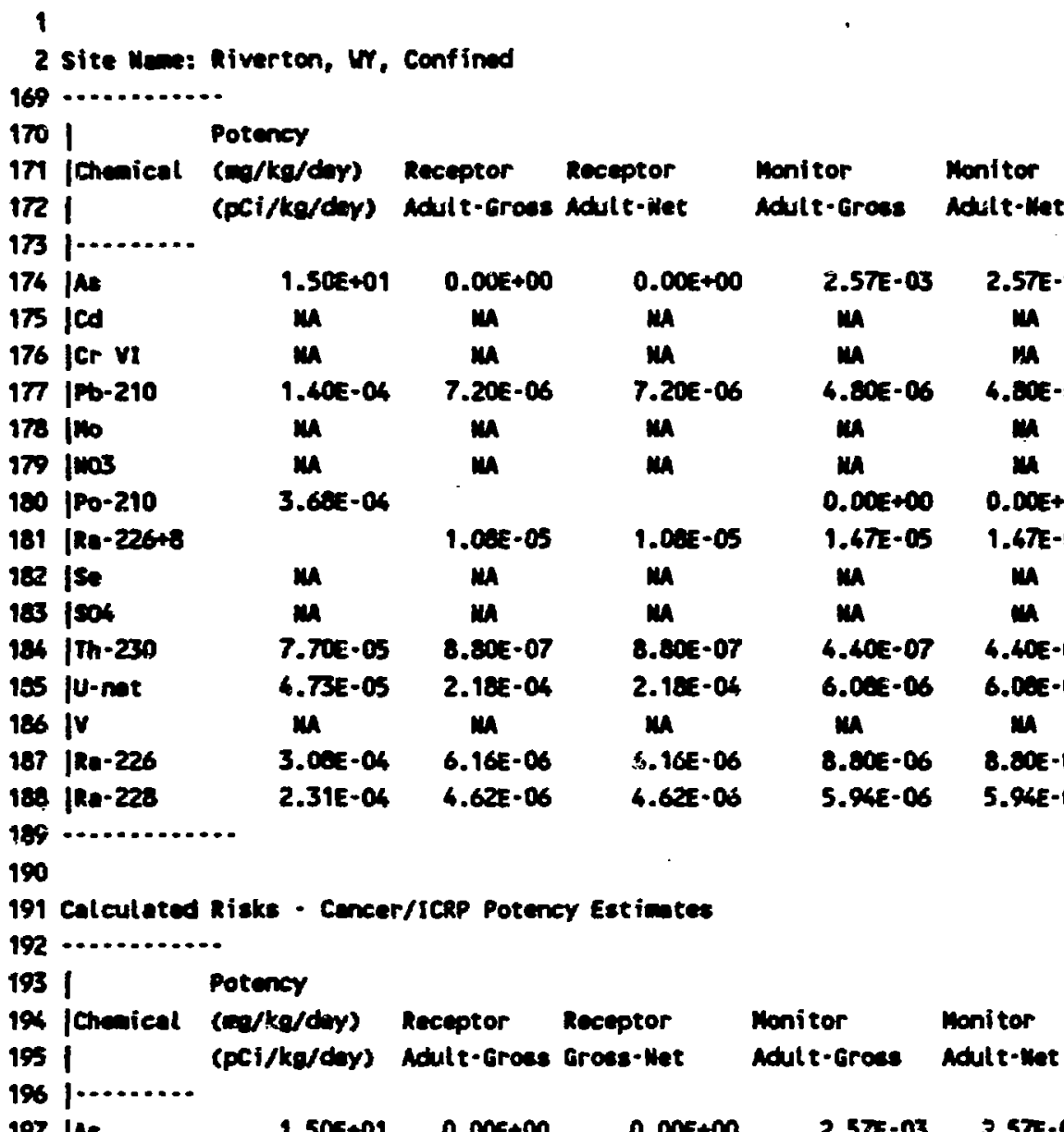

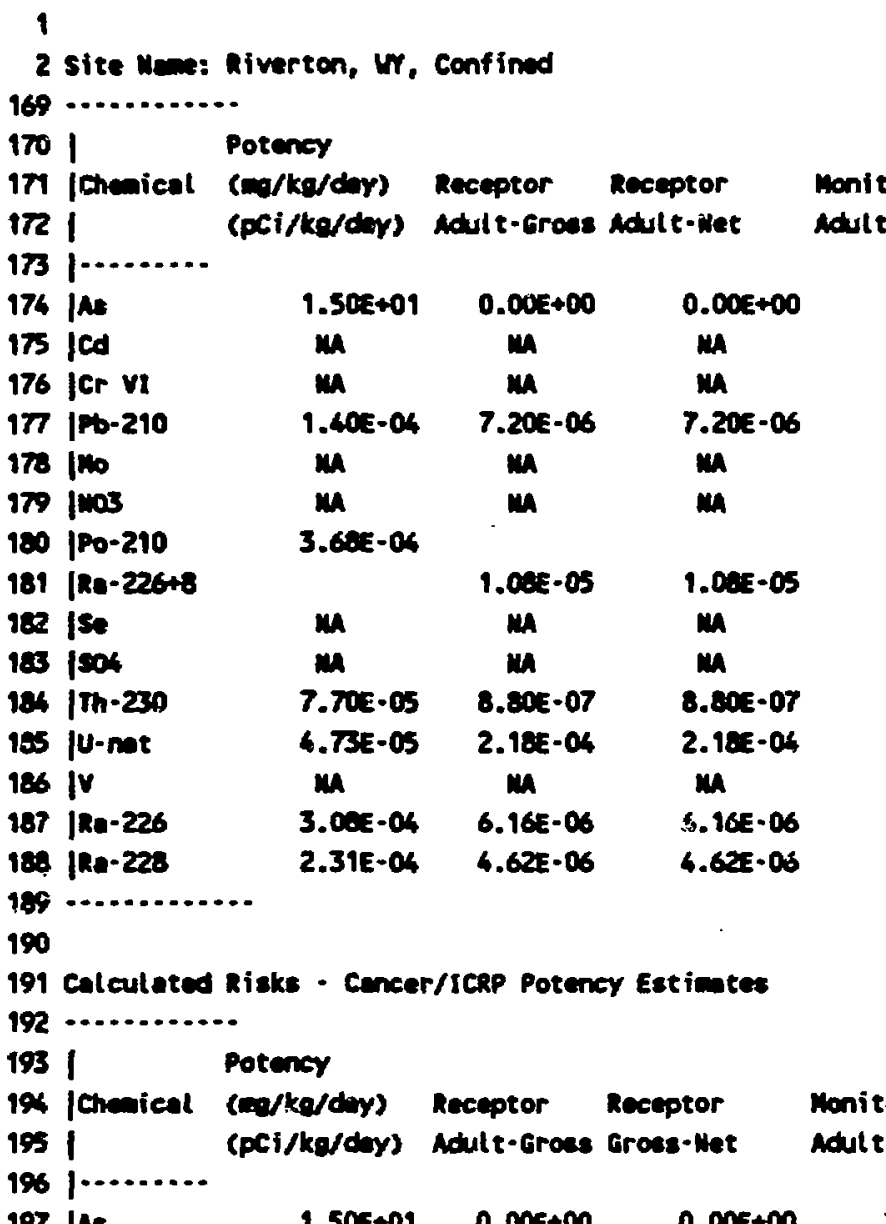

197 las $\quad 1.50 E+01 \quad 0.00 E+00 \quad 0.00 E+00 \quad 2.5 \pi E-03 \quad 2.5 \pi E-03$

198 Ied

$199 \operatorname{lCr} \mathrm{VI}$

M

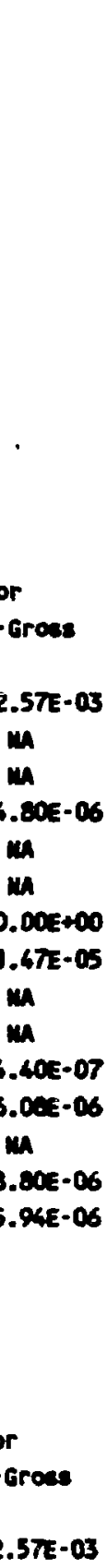

200 IPb-210

201 ino

un

in

in

1.14E-03

5.86E-05

5.86E-05

M

M

202 Imas

in

in

a

3.91E-05

M

203 |po-210

$3.658-06$

M

a)

$3.918-05$

$m$

M

$0.00 E+\infty 00.00 E+\infty 0$ 


\begin{tabular}{|c|c|c|c|c|c|}
\hline 20: |lno-2anes & & $1.025-63$ & $1.05-65$ & $1.421 \cdot 60$ & $1.4: 5 \cdot 63$ \\
\hline 205 ise & $m$ & $m$ & $m$ & $m$ & $m$ \\
\hline 200 iens & $m$ & $m$ & $m$ & $m$ & $M$ \\
\hline $207 \mid 7 n-220$ & $1.18 z-04$ & $1.35 E-06$ & $1.35 x \cdot 05$ & $6.745 \cdot 07$ & $6.74:-07$ \\
\hline 20 |U-net & $5.49 \cdot 05$ & $2.538-04$ & $2.53 x \cdot 04$ & $7.00-05$ & $7.045 \cdot 06$ \\
\hline 200 iv & $m$ & 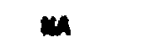 & $m$ & $m$ & $m$ \\
\hline 210 the.226 & $2.6 \pi \cdot 0.04$ & 4.NAE-OS & 4.845-08 & 7.004-0s & $7.005-06$ \\
\hline 211 |Re-220 & $2.7 \pi t-0 s$ & $5.56 E-06$ & $5.565-06$ & $7.124 \cdot 06$ & $7.12 x-06$ \\
\hline
\end{tabular}


APPENDIX D - Critical Evaluation of EPA and ICRP Cancer Risk Models 
Preliminary evaluation of the EPA and ICRP model predictions shows that they may be in error by large amounts. For illustration, only a brief discussion of radium-226 will be made in this paper. Table D-1 gives the lifetime excess risk of ingesting $2 \mathrm{pCi}$ per day of radium-226 for life as predicted by the EPA model [51FR34859]. In particular the distribution of cancers should be noted. The EPA model predicts comparable amounts for leukemia, bone sarcoma, and other neoplasms $(42 \%, 10 \%$, and $48 \%$ respectively).

In contrast, evaluation of direct human data shows a different magnitude of effect and a different distribution by site. Follow-up of radium dial painters found significant excess bone sarcomas and carcinomas of the paranasal sinuses and mastoid air cells. The latter may be due to radon-222 which is the first decay product of radium-226. The best fits of the data by the BEIR IV Committee are a pure quadratic function versus systemic intake of Ra-226 for bone sarcoma and a linear function for sinus cavity carcinomas. An alternate form for bone sarcomas would be a threshold at intake levels well above possible environmental exposures. Excess leukemia and other neoplasms were not observed even at the high levels of exposure suffered. Table D-1 shows the predictions of the dose-response functions derived by BEIR IV at $1 \mathrm{pCi} / \mathrm{l}$. (The uncertainty due to extrapolating to such low exposures is very large.) They are completely different from the EPA predictions both in magnitude and organ distribution.

These observations are important in terms of uranium drinking water standards as well. Since no direct evidence is available on the effects of ingesting uranium, regulation of uranium concentrations is based on analogy with radium [51FR34846].

TABLE D-1

Risk per $\mathrm{pCi} / 1$ for Radium-226 (f $1=0.20)$

Organ Effect Lifetime Risk per Million Persons

EPA BEIR IV

Red Bone Marrow Leukemia $\quad 3.74 \sim 0$

Endosteal Bone Bone Cancer $0.88 \quad 1.4$ E-04

$\begin{array}{lll}\text { Sinus Cavities } & 0 . & 1.8 \mathrm{E}-02\end{array}$

Other $\quad 4.18 \quad-0$ 
Systemic intake is summed through a given year.

The excess risk in that year is then calculated.

The calculation then proceeds to the next year.

Unity life table through age 70

$\begin{array}{cl}\begin{array}{c}1 \mathrm{pCi} / 1 \\ 2 \mathrm{l} / \mathrm{day}\end{array} & \begin{array}{l}\text { drinking water concentration } \\ \text { consumption rate } \\ \text { days per year }\end{array} \\ \begin{array}{c}765.25 \mathrm{~d} / \mathrm{y} \\ 730.5 \mathrm{pCi} / \mathrm{y}\end{array} & \text { annual consumption } \\ 0.2 & \text { fl }-- \text { gut absorption factor } \\ 1.461 \mathrm{E}-04 & \text { annual systemic intake }\end{array}$

*** Bone Sarcomas ***

$I=(6.8+-0.6) 10 \mathrm{E}-08 \mathrm{DE}+02$

(excess only, no cell killing)

I bone sarcomas per person year at risk

D systemic intake in microcuries

6.80E-08 quadratic dose coefficient

age cum $D$ (cum $D) E+02$ lagged risk/y cum risk 5 years

$\begin{array}{rllllll}0 & 0.000 \mathrm{E}+00 & 0.000 \mathrm{E}+00 & 0.000 \mathrm{E}+00 & 0.00 \mathrm{E}+00 & 0.00 \mathrm{E}+00 \\ 1 & 1.461 \mathrm{E}-04 & 2.135 \mathrm{E}-08 & 0.000 \mathrm{E}+00 & 0.00 \mathrm{E}+00 & 0.00 \mathrm{E}+00 \\ 2 & 2.922 \mathrm{E}-04 & 8.538 \mathrm{E}-08 & 0.000 \mathrm{E}+00 & 0.00 \mathrm{E}+00 & 0.00 \mathrm{E}+00 \\ 3 & 4.383 \mathrm{E}-04 & 1.921 \mathrm{E}-07 & 0.000 \mathrm{E}+00 & 0.00 \mathrm{E}+00 & 0.00 \mathrm{E}+00 \\ 4 & 5.844 \mathrm{E}-04 & 3.415 \mathrm{E}-07 & 0.000 \mathrm{E}+00 & 0.00 \mathrm{E}+00 & 0.00 \mathrm{E}+00 \\ 5 & 7.305 \mathrm{E}-04 & 5.336 \mathrm{E}-07 & 0.000 \mathrm{E}+00 & 0.00 \mathrm{E}+00 & 0.00 \mathrm{E}+00 \\ 6 & 8.766 \mathrm{E}-04 & 7.684 \mathrm{E}-07 & 2.135 \mathrm{E}-08 & 1.45 \mathrm{E}-15 & 1.45 \mathrm{E}-15 \\ 7 & 1.023 \mathrm{E}-03 & 1.046 \mathrm{E}-06 & 8.538 \mathrm{E}-08 & 5.81 \mathrm{E}-15 & 7.26 \mathrm{E}-15 \\ 8 & 1.169 \mathrm{E}-03 & 1.366 \mathrm{E}-06 & 1.921 \mathrm{E}-07 & 1.31 \mathrm{E}-14 & 2.03 \mathrm{E}-14 \\ 9 & 1.315 \mathrm{E}-03 & 1.729 \mathrm{E}-06 & 3.415 \mathrm{E}-07 & 2.32 \mathrm{E}-14 & 4.35 \mathrm{E}-14 \\ 10 & 1.461 \mathrm{E}-03 & 2.135 \mathrm{E}-06 & 5.336 \mathrm{E}-07 & 3.63 \mathrm{E}-14 & 7.98 \mathrm{E}-14 \\ 11 & 1.607 \mathrm{E}-03 & 2.583 \mathrm{E}-06 & 7.684 \mathrm{E}-07 & 5.23 \mathrm{E}-14 & 1.32 \mathrm{E}-13 \\ 12 & 1.753 \mathrm{E}-03 & 3.074 \mathrm{E}-06 & 1.046 \mathrm{E}-06 & 7.11 \mathrm{E}-14 & 2.03 \mathrm{E}-13 \\ 13 & 1.899 \mathrm{E}-03 & 3.607 \mathrm{E}-06 & 1.366 \mathrm{E}-06 & 9.29 \mathrm{E}-14 & 2.96 \mathrm{E}-13 \\ 14 & 2.045 \mathrm{E}-03 & 4.184 \mathrm{E}-06 & 1.729 \mathrm{E}-06 & 1.18 \mathrm{E}-13 & 4.14 \mathrm{E}-13 \\ 15 & 2.192 \mathrm{E}-03 & 4.803 \mathrm{E}-06 & 2.135 \mathrm{E}-06 & 1.45 \mathrm{E}-13 & 5.59 \mathrm{E}-13\end{array}$


2.338E- 03 $2.484 \mathrm{E}-03$ 2.630E-03 $2.776 \mathrm{E}-03$ 2.922E-03 $3.068 \mathrm{E}-03$ $3.214 \mathrm{E}-03$ $3.360 \mathrm{E}-03$ $3.506 \mathrm{E}-03$ 3.653E-03 $3.799 \mathrm{E}-03$ $3.945 \mathrm{E}-03$ $4.091 \mathrm{E}-03$ 4.237E-03 4.383E-03 $4.529 \mathrm{E}-03$ $4.675 \mathrm{E}-03$ $4.821 \mathrm{E}-03$ 4.967E-03 5.114E-03 $5.260 \mathrm{E}-03$ $5.406 \mathrm{E}-03$ 5.552E-03 5.698E-03 $5.844 \mathrm{E}-03$ $5.990 \mathrm{E}-03$ $6.136 \mathrm{E}-03$ $6.282 \mathrm{E}-03$ $6.428 \mathrm{E}-03$ 6.574E-03 6.721E-03 6.867E-03 $7.013 \mathrm{E}-03$ $7.159 \mathrm{E}-03$ $7.305 \mathrm{E}-03$ $7.451 E-03$ $7.597 E-03$ $7.743 \mathrm{E}-03$ $7.889 \mathrm{E}-03$ 8.035E-03 8.182E-03 8.328E-03 8.474E-03 $8.620 E-03$ $8.766 \mathrm{E}-03$ 8.912E-03 9.058E-03 $9.204 \mathrm{E}-03$ 9.350E-03 $9.496 \mathrm{E}-03$ 9.643E-03
5.464E-06 6.169E-06 $6.916 \mathrm{E}-06$ $7.706 \mathrm{E}-06$ 8.538E-06 9.413E-06 $1.033 \mathrm{E}-05$ $1.129 \mathrm{E}-05$ $1.229 \mathrm{E}-05$ $1.334 \mathrm{E}-05$ $1.443 \mathrm{E}-05$ $1.556 \mathrm{E}-05$ $1.673 \mathrm{E}-05$ 1.795E-05 $1.921 \mathrm{E}-05$ $2.051 \mathrm{E}-05$ 2.186E-05 $2.324 \mathrm{E}-05$ $2.468 \mathrm{E}-05$ 2.615E-05 $2.766 \mathrm{E}-05$ $2.922 \mathrm{E}-05$ $3.082 \mathrm{E}-05$ $3.247 \mathrm{E}-05$ $3.415 \mathrm{E}-05$ $3.588 \mathrm{E}-05$ 3.765E-05 $3.947 \mathrm{E}-05$ 4.132E-05 4.322E-05 4.517E-05 4.715E-05 4.918E-05 5. $125 \mathrm{E}-05$ $5.336 \mathrm{E}-05$ 5.552E-05 5.772E-05 5.996E-05 6.224E-05 6.457E-05 6.694E-05 $6.935 \mathrm{E}-05$ $7.181 \mathrm{E}-05$ $7.430 E-05$ 7.684E-05 $7.943 \mathrm{E}-05$ 8.205E-05 8.472E-05 $8.743 E-05$ 9.018E-05 $9.298 \mathrm{E}-05$
2.583E-06 1.76E-13 7.34E-13 $3.074 \mathrm{E}-062.09 \mathrm{E}-13$ 9.43E- 13 3.607E-06 2.45E-13 1.19E-12 4.184E-06 2.84E-13 1.47E-12 4.803E-06 3.27E- $13 \quad 1.80 \mathrm{E}-12$ 5.464E-06 3.72E-13 2.17E-12 6.169E-06 4.19E-13 2.59E-12 $6.916 \mathrm{E}-06 \quad 4.70 \mathrm{E}-13 \quad 3.06 \mathrm{E}-12$ 7.706E-06 5.24E-13 3.59E-12 8.538E-06 5.81E-13 4.17E-12 $9.413 \mathrm{E}-06 \quad 6.40 \mathrm{E}-13 \quad 4.81 \mathrm{E}-12$ $1.033 \mathrm{E}-05 \quad 7.03 \mathrm{E}-13 \quad 5.51 \mathrm{E}-12$ $1.129 \mathrm{E}-05$ 7.68E-13 6.28E-12 $1.229 \mathrm{E}-05 \quad 8.36 \mathrm{E}-13 \quad 7.11 \mathrm{E}-12$ $1.334 \mathrm{E}-05$ 9.07E-13 8.02E-12 $1.443 \mathrm{E}-05 \quad 9.81 \mathrm{E}-13 \quad 9.00 \mathrm{E}-12$ $1.556 \mathrm{E}-05 \quad 1.06 \mathrm{E}-12 \quad 1.01 \mathrm{E}-11$ $1.673 \mathrm{E}-05 \quad 1.14 \mathrm{E}-12 \quad 1.12 \mathrm{E}-11$ $1.795 \mathrm{E}-05$ 1.22E-12 $1.24 \mathrm{E}-11$ $1.921 \mathrm{E}-05$ 1.31E-12 1.37E-11 $2.051 \mathrm{E}-05 \quad 1.39 \mathrm{E}-12 \quad 1.51 \mathrm{E}-11$ $2.186 \mathrm{E}-05 \quad 1.49 \mathrm{E}-12 \quad 1.66 \mathrm{E}-11$ 2.324E-05 1.58E-12 1.82E-11 $2.468 \mathrm{E}-051.68 \mathrm{E}-12 \quad 1.99 \mathrm{E}-11$ $2.615 \mathrm{E}-051.78 \mathrm{E}-122.16 \mathrm{E}-11$ $2.766 \mathrm{E}-05$ 1.88E-12 2.35E-11 $2.922 \mathrm{E}-051.99 \mathrm{E}-122.55 \mathrm{E}-11$ 3.082E-05 2.10E-12 2.76E-11 3.247E-05 2.21E-12 2.98E-11 $3.415 \mathrm{E}-05$ 2.32E-12 3.21E-11 $3.588 \mathrm{E}-05$ 2.44E-12 3.46E- 11 3.765E-05 2.56E-12 3.71E-11 3.947E-05 2.68E- 12 3.98E-11 4.132E-05 2.8IE-12 4.26E-I1 $4.322 \mathrm{E}-05$ 2.94E- $124.56 \mathrm{E}-11$ 4.517E-05 3.07E-12 4.86E-11 $4.715 \mathrm{E}-05$ 3.21E-12 5.18E-11 $4.918 \mathrm{E}-05$ 3.34E-12 5.52E-11 $5.125 \mathrm{E}-05$ 3.48E-12 5.87E-11 $5.336 \mathrm{E}-05 \quad 3.63 \mathrm{E}-12 \quad 6.23 \mathrm{E}-11$ $5.552 \mathrm{E}-05$ 3.78E-12 6.61E-11 5.772E-05 3.92E- $12 \quad 7.00 \mathrm{E}-11$ $5.996 \mathrm{E}-054.08 \mathrm{E}-12 \quad 7.41 \mathrm{E}-11$ 6.224E-05 4.23E-12 7.83E-11 6.457E-05 4.39E-12 8.27E-11 6.694E-05 4.55E-12 8.73E-11 6.935E-05 4.72E-12 9.20E-11 $7.18 \mathrm{IE}-05$ 4.88E-12 9.69E-11 $7.430 \mathrm{E}-05 \quad 5.05 \mathrm{E}-12 \quad 1.02 \mathrm{E}-10$ $7.684 \mathrm{E}-05 \quad 5.23 \mathrm{E}-12 \quad 1.07 \mathrm{E}-10$ $7.943 \mathrm{E}-05$
$5.40 \mathrm{E}-12$ 
$67 \quad 9.789 \mathrm{E}-03$

$68 \quad 9.935 \mathrm{E}-03$

$69 \quad 1.008 \mathrm{E}-02$

$70 \quad 1.023 \mathrm{E}-02$
$9.582 \mathrm{E}-05$

$9.870 \mathrm{E}-05$

$1.016 \mathrm{E}-04$

1.046E-04
8.205E-05 5.58E-12 $1.18 \mathrm{E}-10$

8.472E-05 5.76E-12 $1.24 E-10$

8.743E-05 5.95E-12 $1.30 \mathrm{E}-10$

9.018E-05 6.13E-12 1.36E-10

Paranasal Sinus and Mastoid Air Cell Carcinomas ***

$I=(1.6+-0.2) 10 \mathrm{E}-05 \mathrm{D}$

(excess only, no cell killing)

I carcinomas per person year at risk

D systemic intake in microcuries

1.60E-05

age cum $D$ linear dose coefficient

lagged risk/y cum risk 10 years

$0.000 \mathrm{E}+000.00 \mathrm{E}+000.00 \mathrm{E}+00$

$0.000 \mathrm{E}+00 \quad 0.00 \mathrm{E}+00 \quad 0.00 \mathrm{E}+00$

$0.000 \mathrm{E}+00 \quad 0.00 \mathrm{E}+000.00 \mathrm{E}+00$

$0.000 \mathrm{E}+000.00 \mathrm{E}+000.00 \mathrm{E}+00$

$0.000 \mathrm{E}+00 \quad 0.00 \mathrm{E}+00 \quad 0.00 \mathrm{E}+00$

$0.000 \mathrm{E}+00 \quad 0.00 \mathrm{E}+00 \quad 0.00 \mathrm{E}+00$

$0.000 \mathrm{E}+00 \quad 0.00 \mathrm{E}+00 \quad 0.00 \mathrm{E}+00$

$0.000 \mathrm{E}+00 \quad 0.00 \mathrm{E}+00 \quad 0.00 \mathrm{E}+00$

$0.000 \mathrm{E}+000.00 \mathrm{E}+000.00 \mathrm{E}+00$

$0.000 \mathrm{E}+000.00 \mathrm{E}+000.00 \mathrm{E}+00$

$0.000 \mathrm{E}+00 \quad 0.00 \mathrm{E}+00 \quad 0.00 \mathrm{E}+00$

$1.461 \mathrm{E}-04$ 9.93E- 12 9.93E-12

2.922E-04 1.99E-11 2.98E-11

4.383E-04 2.98E-11 5.96E-11

5.844E-04 3.97E-11 9.93E-11

7.305E-04 4.97E-11 $1.49 \mathrm{E}-10$

8.766E-04 5.96E-11 2.09E-10

$1.023 E-03 \quad 6.95 \mathrm{E}-112.78 \mathrm{E}-10$

$1.169 \mathrm{E}-03$ 7.95E-11 3.58E-10

$1.315 \mathrm{E}-03$ 8.94E-11 4.47E-10

$1.461 \mathrm{E}-03$ 9.93E- $11 \quad 5.46 \mathrm{E}-10$

$1.607 \mathrm{E}-03 \quad 1.09 \mathrm{E}-106.56 \mathrm{E}-10$

$1.753 \mathrm{E}-03 \quad 1.19 \mathrm{E}-107.75 \mathrm{E}-10$

$1.899 \mathrm{E}-03 \quad 1.29 \mathrm{E}-109.04 \mathrm{E}-10$

2.045E-03 $1.39 \mathrm{E}-10 \quad 1.04 \mathrm{E}-09$

$2.192 \mathrm{E}-03 \quad 1.49 \mathrm{E}-101.19 \mathrm{E}-09$

$2.338 \mathrm{E}-03$ 1.59E- 10 1.35E-09

$2.484 \mathrm{E}-03$ ।.69E- 10 I.52E-09

$2.630 \mathrm{E}-03 \quad 1.79 \mathrm{E}-10 \quad 1.70 \mathrm{E}-09$

$2.776 \mathrm{E}-03 \quad 1.89 \mathrm{E}-10 \quad 1.89 \mathrm{E}-09$

$2.922 \mathrm{E}-03 \quad 1.99 \mathrm{E}-102.09 \mathrm{E}-09$

$3.068 \mathrm{E}-03 \quad 2.09 \mathrm{E}-102.29 \mathrm{E}-09$

$3.214 E-03$ 2.19E-10 2.51E-09 


$\begin{array}{llllll}33 & 4.821 \mathrm{E}-03 & 3.360 \mathrm{E}-03 & 2.29 \mathrm{E}-10 & 2.74 \mathrm{E}-09 \\ 34 & 4.967 \mathrm{E}-03 & 3.506 \mathrm{E}-03 & 2.38 \mathrm{E}-10 & 2.98 \mathrm{E}-09 \\ 35 & 5.114 \mathrm{E}-03 & 3.653 \mathrm{E}-03 & 2.48 \mathrm{E}-10 & 3.23 \mathrm{E}-09 \\ 36 & 5.260 \mathrm{E}-03 & 3.799 \mathrm{E}-03 & 2.58 \mathrm{E}-10 & 3.49 \mathrm{E}-09 \\ 37 & 5.406 \mathrm{E}-03 & 3.945 \mathrm{E}-03 & 2.68 \mathrm{E}-10 & 3.76 \mathrm{E}-09 \\ 38 & 5.552 \mathrm{E}-03 & 4.091 \mathrm{E}-03 & 2.78 \mathrm{E}-10 & 4.03 \mathrm{E}-09 \\ 39 & 5.698 \mathrm{E}-03 & 4.237 \mathrm{E}-03 & 2.88 \mathrm{E}-10 & 4.32 \mathrm{E}-09 \\ 40 & 5.844 \mathrm{E}-03 & 4.383 \mathrm{E}-03 & 2.98 \mathrm{E}-10 & 4.62 \mathrm{E}-09 \\ 41 & 5.990 \mathrm{E}-03 & 4.529 \mathrm{E}-03 & 3.08 \mathrm{E}-10 & 4.93 \mathrm{E}-09 \\ 42 & 6.136 \mathrm{E}-03 & 4.675 \mathrm{E}-03 & 3.18 \mathrm{E}-10 & 5.25 \mathrm{E}-09 \\ 43 & 6.282 \mathrm{E}-03 & 4.821 \mathrm{E}-03 & 3.28 \mathrm{E}-10 & 5.57 \mathrm{E}-09 \\ 44 & 6.428 \mathrm{E}-03 & 4.967 \mathrm{E}-03 & 3.38 \mathrm{E}-10 & 5.91 \mathrm{E}-09 \\ 15 & 6.574 \mathrm{E}-03 & 5.114 \mathrm{E}-03 & 3.48 \mathrm{E}-10 & 6.26 \mathrm{E}-09 \\ 46 & 6.721 \mathrm{E}-03 & 5.260 \mathrm{E}-03 & 3.58 \mathrm{E}-10 & 6.62 \mathrm{E}-09 \\ 47 & 6.867 \mathrm{E}-03 & 5.406 \mathrm{E}-03 & 3.68 \mathrm{E}-10 & 6.98 \mathrm{E}-09 \\ 48 & 7.013 \mathrm{E}-03 & 5.552 \mathrm{E}-03 & 3.78 \mathrm{E}-10 & 7.36 \mathrm{E}-09 \\ 49 & 7.159 \mathrm{E}-03 & 5.698 \mathrm{E}-03 & 3.87 \mathrm{E}-10 & 7.75 \mathrm{E}-09 \\ 50 & 7.305 \mathrm{E}-03 & 5.844 \mathrm{E}-03 & 3.97 \mathrm{E}-10 & 8.15 \mathrm{E}-09 \\ 51 & 7.451 \mathrm{E}-03 & 5.990 \mathrm{E}-03 & 4.07 \mathrm{E}-10 & 8.55 \mathrm{E}-09 \\ 52 & 7.597 \mathrm{E}-03 & 6.136 \mathrm{E}-03 & 4.17 \mathrm{E}-10 & 8.97 \mathrm{E}-09 \\ 53 & 7.743 \mathrm{E}-03 & 6.282 \mathrm{E}-03 & 4.27 \mathrm{E}-10 & 9.40 \mathrm{E}-09 \\ 54 & 7.889 \mathrm{E}-03 & 6.428 \mathrm{E}-03 & 4.37 \mathrm{E}-10 & 9.84 \mathrm{E}-09 \\ 55 & 8.035 \mathrm{E}-03 & 6.574 \mathrm{E}-03 & 4.47 \mathrm{E}-10 & 1.03 \mathrm{E}-08 \\ 56 & 8.182 \mathrm{E}-03 & 6.721 \mathrm{E}-03 & 4.57 \mathrm{E}-10 & 1.07 \mathrm{E}-08 \\ 57 & 8.328 \mathrm{E}-03 & 6.867 \mathrm{E}-03 & 4.67 \mathrm{E}-10 & 1.12 \mathrm{E}-08 \\ 58 & 8.474 \mathrm{E}-03 & 7.013 \mathrm{E}-03 & 4.77 \mathrm{E}-10 & 1.17 \mathrm{E}-08 \\ 59 & 8.620 \mathrm{E}-03 & 7.159 \mathrm{E}-03 & 4.87 \mathrm{E}-10 & 1.22 \mathrm{E}-08 \\ 60 & 8.766 \mathrm{E}-03 & 7.305 \mathrm{E}-03 & 4.97 \mathrm{E}-10 & 1.27 \mathrm{E}-08 \\ 61 & 8.912 \mathrm{E}-03 & 7.451 \mathrm{E}-03 & 5.07 \mathrm{E}-10 & 1.32 \mathrm{E}-08 \\ 62 & 9.058 \mathrm{E}-03 & 7.597 \mathrm{E}-03 & 5.17 \mathrm{E}-10 & 1.37 \mathrm{E}-08 \\ 63 & 9.204 \mathrm{E}-03 & 7.743 \mathrm{E}-03 & 5.27 \mathrm{E}-10 & 1.42 \mathrm{E}-08 \\ 64 & 9.350 \mathrm{E}-03 & 7.889 \mathrm{E}-03 & 5.36 \mathrm{E}-10 & 1.48 \mathrm{E}-08 \\ 65 & 9.496 \mathrm{E}-03 & 8.035 \mathrm{E}-03 & 5.46 \mathrm{E}-10 & 1.53 \mathrm{E}-08 \\ 66 & 9.643 \mathrm{E}-03 & 8.182 \mathrm{E}-03 & 5.56 \mathrm{E}-10 & 1.59 \mathrm{E}-08 \\ 67 & 9.789 \mathrm{E}-03 & 8.328 \mathrm{E}-03 & 5.66 \mathrm{E}-10 & 1.64 \mathrm{E}-08 \\ 68 & 9.935 \mathrm{E}-03 & 8.474 \mathrm{E}-03 & 5.76 \mathrm{E}-10 & 1.70 \mathrm{E}-08 \\ 69 & 1.008 \mathrm{E}-02 & 8.620 \mathrm{E}-03 & 5.86 \mathrm{E}-10 & 1.76 \mathrm{E}-08 \\ 70 & 1.023 \mathrm{E}-02 & 8.766 \mathrm{E}-03 & 5.96 \mathrm{E}-10 & 1.82 \mathrm{E}-08\end{array}$

